\title{
Prognostic and predictive factors in primary breast cancer
}

Citation for published version (APA):

Hupperets, P. S. G. J. (1995). Prognostic and predictive factors in primary breast cancer. [Doctoral Thesis, Maastricht University]. Datawyse / Universitaire Pers Maastricht. https://doi.org/10.26481/dis.19951220ph

Document status and date:

Published: 01/01/1995

DOI:

10.26481/dis.19951220ph

Document Version:

Publisher's PDF, also known as Version of record

\section{Please check the document version of this publication:}

- A submitted manuscript is the version of the article upon submission and before peer-review. There can be important differences between the submitted version and the official published version of record.

People interested in the research are advised to contact the author for the final version of the publication, or visit the DOI to the publisher's website.

- The final author version and the galley proof are versions of the publication after peer review.

- The final published version features the final layout of the paper including the volume, issue and page numbers.

Link to publication

\footnotetext{
General rights rights.

- You may freely distribute the URL identifying the publication in the public portal. please follow below link for the End User Agreement:

www.umlib.nl/taverne-license

Take down policy

If you believe that this document breaches copyright please contact us at:

repository@maastrichtuniversity.nl

providing details and we will investigate your claim.
}

Copyright and moral rights for the publications made accessible in the public portal are retained by the authors and/or other copyright owners and it is a condition of accessing publications that users recognise and abide by the legal requirements associated with these

- Users may download and print one copy of any publication from the public portal for the purpose of private study or research.

- You may not further distribute the material or use it for any profit-making activity or commercial gain

If the publication is distributed under the terms of Article $25 \mathrm{fa}$ of the Dutch Copyright Act, indicated by the "Taverne" license above, 


\title{
PROGNOSTIC AND PREDICTIVE FACTORS
}

\author{
IN PRIMARY BREAST CANCER
}


P.S.G.J. Hupperets, Maastricht 1995

CIP-DATA KONINKLIJKE BIBLIOTHEEK, DEN HAAG

Hupperets, Pierre Stefanus Gerardus Johannes

Prognostic and predictive factors in primary breast cancer /

Pierre Stefanus Gerardus Johannes Hupperets. -

Maastricht: Universitaire Pers Maastricht. -IIl.

Thesis University of Limburg Maastricht. - With ref. -

With summary in Dutch.

ISBN 90-5278-206-7

Subject beadings: breast cancer; chemo-hormonal treatment /

breast cancer; prognostic factors / breast cancer; predictive factors.

Cover illustration Le cri: Rodin

The studies in this thesis and prining of this thesis were made possible by financial support of Pharmacia BV, Ciba BV, Zeneca, Rhône Poulenc Rorer, AMGEN and the Comprehensive Cancer Center Limburg (KL). 


\title{
PROGNOSTIC AND PREDICTIVE FACTORS
}

\section{IN PRIMARY BREAST CANCER}

\author{
PROEFSCHRIFT
}

ter verkrijging van de graad van doctor

aan de Rijksuniversiteit Limburg te Maastricht, op gezag van de Rector Magnificus, Prof. Mr. M.J. Cohen, volgens het besluit van het College van Dekanen, in het openbaar te verdedigen

op woensdag 20 december 1995 om 14.00 uur

door

Pierre Stefanus Gerardus Johannes Hupperets

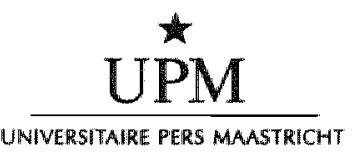




\section{Promotores:}

Prof.dr. G.H. Bliham, Academisch Ziekenhuis Utrecht Prof.dr. H.F.P. Hillen

\section{Co-promotor:}

Dr. H.C Schouten

\section{Beoordelingscommissie:}

Prof.dr. M.F. von Meyenfeldt (voorzitter)

Prof.dr. J.W. Arends

Dr. L.V.A.M. Beex, Academisch Ziekenhuis Nijmegen

Pof.dr. F.C.S. Ramaekers

Prof.dr. D.J.Th. Wagener, Academisch Ziekenhuis Nijmegen 
To all breast cancer patients who suffered from this unpredictable disease 


\section{CONTENTS}

\section{Chapter I. Introduction 9}

Chapter II. Adjuvant Chemo-hormonal Therapy with Cyclophosphamide, Doxorubicin and 5-Fluorouracil (CAF) with or without Medroxyprogesterone Acetate for Node-positive Breast Cancer Patients. 33

Chapter IIa. Adjuvant Chemo-hormonal Therapy with Cyclophosphamide, Doxorubicin and 5-Fluorouracil (CAF) with or without Medroxyprogesterone Acetate for Node-positive Breast Cancer Patients. Update at 7 years follow-up. 49

Chapter III. The Prognostic Significance of Steroid Receptor Activity in Tumour Tissues of Patients with Primary Breast Cancer. 55

Chapter IV. The Prognostic Value of Flow Cytometry in Women with Nodenegative Primary Breast Cancer. 69

Chapter V. The Prognostic and Predictive Value of Flow Cytometry in Nodepositive Breast Cancer Patients. 85

Chapter VI. Ploidy and S-phase Fractions (SPF) of Primary Breast Cancers and their Nodal Metastases. IOI

Chapter VII. Summary and General Discussion. 113

Samenvatting. 123

Publicaties. 129

Dankwoord. 131

Curriculum vitae. 133 


\section{INTRODUCTION}




\section{INTRODUCTION}

Breast cancer is a major public health problem. Since 1975 the incidence of the disease has increased by an average of $1 \%$ per year, heightening concern among physicians and women in general. On the basis of incidence rates for 1975 through 1987 and mortality rates for 1987 in the United States ${ }^{1,2}$, and the Netherlands ${ }^{3}, 10.7-12$ percent of all women will be diagnosed with breast cancer and 3.5-3.9 percent will die of the disease. The impact of breast cancer is magnified because women are at a cumulative risk from their middle to later years. The incidence rates of breast cancer increase steadily during the fourth decade and become substantial before the age of 50 , thus creating a long-lasting source of concerm for women and a need for vigilance. After menopause the incidence rates continue to increase with age. Breast cancer is the leading cause of death among Western-European and American ${ }^{2}$ women who are 40 to 55 years of age. In less prosperous parts of the world and in the Far East, the same pattern of increase with age is seen ${ }^{4}$, but the absolute rates are much lower at each age. In Japan, for example, the overall incidence of breast cancer is only about one fifth of that in the United States ${ }^{5}$. Long-term increases in the incidence of breast cancer are being observed worldwide in both industrialized and developing countries ${ }^{6.7}$. The age adjusted mortality rates have been remarkably stable, despite increases in incidence which can be the result of more complete reporting of incident cases, increases of a more benign form of disease, earlier detection, or advances in treatment.

A number of variables that predict for the occurrence of breast cancer and their typical relative risks are described briefly in table I. As can be appreciated, the established risk factors for breast cancer - a family history of breast cancer, early menarche, late age at first childbirth, late age of menopause, history of benign breast disease and exposure to ionizing radiation - are generally associated with only weak or moderate elevations in risk. The exceptions occur in subgroups of these variables; for example a family history of breast cancer at a young age or a family history of bilateral disease ${ }^{8.9}$. An intensive search for DNA markers for familial risk is ongoing. A category of inherited breast cancers is associated with a gene on chromosome $17 \mathrm{q}$, termed breast cancer 1 or BRCA $1^{10,11}$. 
Table I Variables predicting the occurrence of breast cancer.

\begin{tabular}{lc}
\hline Risk factor & Relative risk \\
\hline Family history (maternal) & \\
one first degree relative & 2 \\
first-degree relative diagnosed <40 years & 3 \\
two first-degree relatives & 4 \\
bilateral breast cancer & 4 \\
Benign breast disease & 2 \\
biopsy confirmed & 4 \\
atypical thyperplasia & 1.5 \\
mammographic (dysplasia/prominent ducts) & 10 \\
Lobular carcinoma in situ & 2 \\
Nulliparity/first child when > 30 years & 2 \\
\hline
\end{tabular}

\section{STAGING}

The clinical course of breast cancer is determined by the extent of the disease. Staging refers to procedures performed to determine groups of patients with a same extent of local, regional or distant cancer involwement. Breast cancer is staged initially on a clinical basis, according to the results of physical examination, laboratory and radiologic evaluations. This information can be useful in choosing treatments, estimating prognosis and comparing the results of different treatment programs. An internationally recognized staging system - the TNM system - has been accepted by both the Union Internationale Contre le Cancer (UICC) and the American Joint Commission on Cancer Staging and End-Results Reporting ${ }^{12}$. This system is based on the extent of the tumour, the involvement of lymph nodes, and the presence of metastases (table II).

Because the clinical evaluation of axillary - node involvement has considerable false positive and false negative rates, pathological (post operative) staging based on histologic evaluation of the axillary specimen provides a more accurate assessment of prognosis for the individual patient. The prognosis of breast cancer is clearly related to extent of axillary involvement, therefore, it has become conventional to categorize patients according to the number of involved nodes - that is no positive nodes (node-negative), 1 to 3 positive nodes, 4 to 9 positive nodes and 10 or more positive nodes.

\section{HISTOLOGY OF INVASIVE BREAST CANCER}

Invasive breast cancers are a histologically heterogeneous group of lesions. Most breast carcinomas are adenocarcinomas and are classified as either ductal or lobular, corresponding to the ducts and lobules of the normal breast. In addition, there are a number of less common types of invasive breast carcinomas. The various types have slightly different prognosis, but it is not known whether the response to chemotherapy differs, since patients in therapeutic trials have not been stratified according to histologic type. 
Table II TNM system and clinical stage

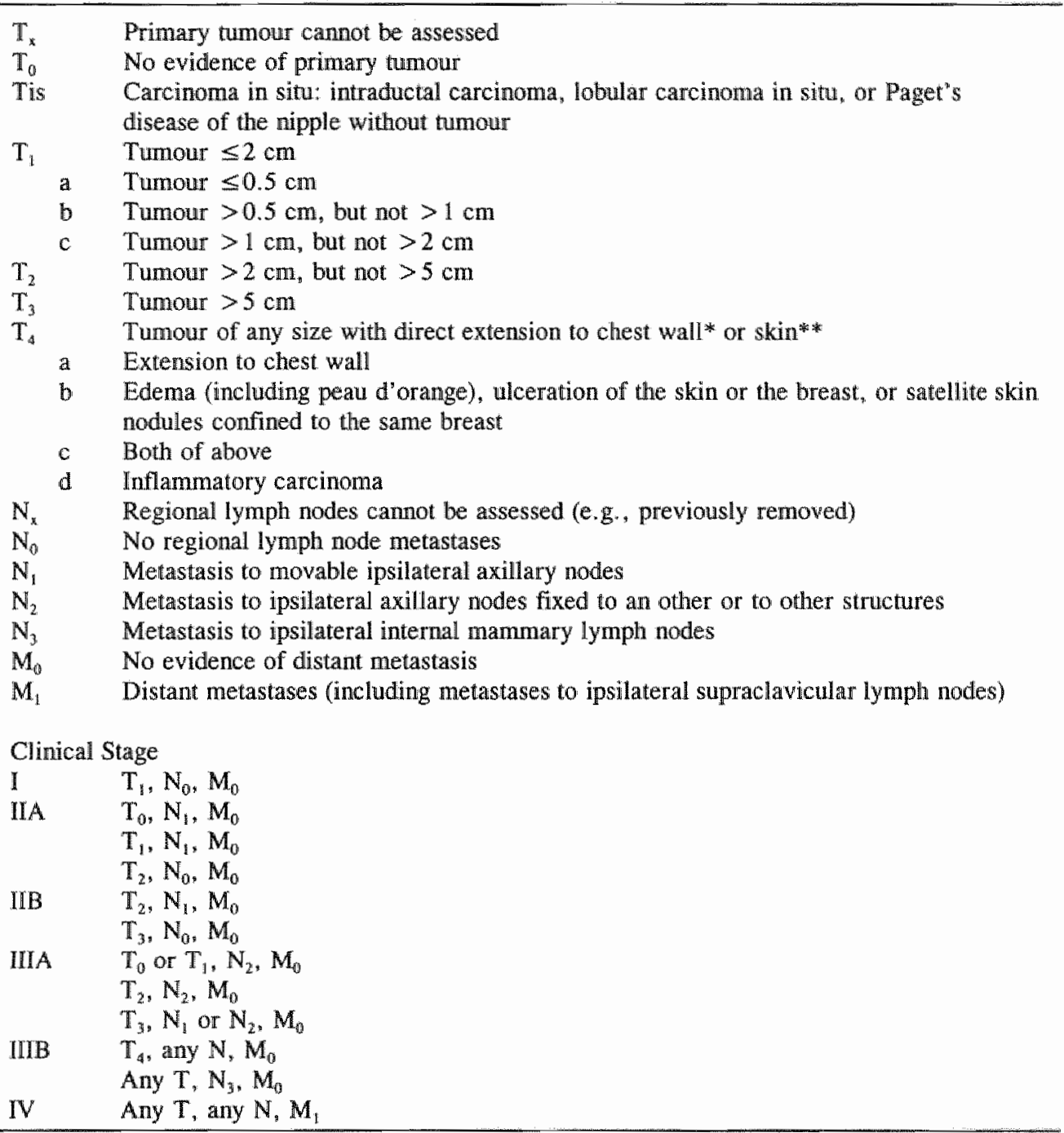

* The chest wall includes the ribs, intercostal muscles, and serratus anterior muscle, but not the pectoral muscle.

* Dimpling of the skin, nipple retraction, or any skin changes except those listed for $T_{40}$ may occur in $\mathrm{T}_{1}, \mathrm{~T}_{2}$ or $\mathrm{T}_{3}$ without affecting the classification. 


\section{ADJUVANT THERAPY OF BREAST CANCER}

The demonstration that adjuvant systemic treatment can prolong the disease-free interval and improve overall survival has been a major advance in the management of breast cancer. Randomized clinical trials of systemic adjuvant chemotherapy were pioneered by the Milan group ${ }^{13}$ and the NSABP-National Surgicall Adjuvant Breast and Bowel Projectgroup ${ }^{14}$ and provided the first evidence of the benefit of cytotoxic chemotherapy in breast cancer patients with involvement of the axillary lymph nodes, particularly in younger wornen.

The Nolvadex Adjuvant Trial Organization ${ }^{15}$ and the Scotkish Trial ${ }^{16}$ demonstrated a similar benefit for tamoxifen in older women. These early studies were followed by a large number of national and international multicenter cooperative clinical trials. Most of these trials had relatively simple designs, comparing multidrug regimens with no treatment or comparing tamoxifen with placebo. In addition, there have been a number of trials testing the value of combining chemotherapy and tamoxifen ${ }^{17.18}$.

On the basis of avallable information a number of general conclusions on the effects of adjuvant systemic treatment can be drawn ${ }^{19,20,21}$. The effect on disease-free interval (DFI) has generally been larger than the effect on overall survival (OS). The effect of polychemotherapy has been larger than the effect of mono-drug therapy. Polychemotherapy has a greater effect in premenopausal patients, and tamoxifen is more effective in postmenopausal women. The administration of full doses of chemotherapy is associated with improved results. Sustained chemotherapy after six months has no additional benefit whereas several years of tamoxifen therapy has provided more advantages than a single year of use. No consistent evidence supports the addition of tamoxifen to chemotherapy in younger women; in older women, there is some evidence that the addition of chemotherapy containing anthracyclines to tamoxifen results in improved $\mathrm{OS}^{\mathrm{H}}$. The benefit of tamoxifen is greater in patients with oestrogen-receptor positive tumours than in those with oestrogen-receptor negative tumours.

Because the overall effects of most individual trials particularly on survival have been small, relatively large numbers of patients are required to observe small but clinically important effects in subgroups of patients. This has led to the use of a combined analysis (meta-analysis) of all breast cancer trials, based on a worldwide collaboration of 133 randomized trials with 31.000 recurrences of disease and 24.000 deaths among 75.000 women ${ }^{19}$. Table III lists the reduction in the annual odds of either recurrence or death after treatment, as compared with the annual odds for the control group, as a function of therapy and age.

The reduction is an approximation of the relative risk in the rate of recurrence or death in the treated group as compared with the control group. The absolute benefit of adjuvant therapy will depend on the patients initial risk of dying from the disease. If, for example, adjuvant therapy reduces the relative risk of death by $30 \%$, then, the absolute benefit (the additional percentage of patients alive at 10 years) will be about 4 percent for patients with stage I disease and good prognostic factors, who have a $10-20 \%$ risk of death from breast cancer and $8 \%$ for patients with stage I disease and poor prognostic factors, who have a $20-40 \%$ risk of death. If adjuvant therapy reduces the relative risk by $15 \%$, the corresponding absolute benefit, in the latter example, will be 10-20\%. 
Although meta-analysis can detect small benefits of treatment, they usually do not identify differences between trials in such variables as dose intensity, drug selection and sequencing, or population differences that may be important in the outcome.

One of the most controversial aspects on the use of adjuvant therapy is its role in breast cancer patients with axillary nodes free of metastases. The rate of recurrence in this group of patients is approximately $10-40 \%$ and a series of recent trials have established that adjuvant therapy is of value for at least some of these women ${ }^{22,23,24,25}$. Guidelines for the use of adjuvant chemotherapy in patients with node-negative cancer have not been established. Adjuvant therapy is currently being explored in node-negative patients with unfavourably prognostic factors including steroid-receptor negative tumours.

Table III Reduction in the annual odds of recurrence or death after treatment

\begin{tabular}{llcccc}
$\begin{array}{c}\text { Type of } \\
\text { therapy }\end{array}$ & $\begin{array}{c}\text { Comparison } \\
\text { group }\end{array}$ & $<50 \mathrm{yr}$ & $\geq 50 \mathrm{yr}$ & $<50 \mathrm{yr}$ & $\geq 50 \mathrm{yr}$ \\
\hline Polychemother. & No chemother. & $36 \pm 5$ & $24 \pm 3$ & $24 \pm 5$ & $13 \pm 4$ \\
Tamoxifen & No tamoxifen & $12 \pm 4$ & $29 \pm 2$ & $6 \pm 5$ & $20 \pm 2$ \\
\hline
\end{tabular}

* Data are from the Early Breast Cancer Trialists' Collaborative Group (17) plus-minus values are means $\pm \mathrm{SD}$.

\section{METASTATIC BREAST CANCER}

Metastatic breast cancer remains an incurable disease, although systemic therapy can provide effective temporary palliation for many patients. Initial combination chemotherapy for metastatic breast cancer produces response rates in the range of $50 \%$ to $70 \%$, but only $10 \%$ to $20 \%$ of the patients achieve complete remissions ${ }^{26,27.28}$. For most patients, remission duration is relatively brief, and prolongation of median survival with any chemotherapy regimen is modest at best ${ }^{29}$. Several trials carried out over the past 15 years have shown some improvement in response rates and frequency of complete remission, but they have not demonstrated a consistent increase in the duration of response or in survival ${ }^{30,31,32,33}$. When patients relapse after first line chemotherapy, second and third line regimens produce lower response rates of shorter duration. At the present time, optimall chemotherapy for most patients aims at maximizing response rates while limiting drug-induced toxicity.

\section{PROGNOSTIC FACTORS}

The demonstrated benefit of adjuvant systemic treatment has prompted intense interest in identifying clinical and laboratory factors that can be used to select patients who do or do not need further therapy because of their prognosis. In addition, there is interest to select patients likely to respond to a particular form of adjuwant systemic therapy. The presence and extent of axillary-node metastases is the best-established prognostic factor ${ }^{32.33}$. The following factors are of prognostic importance in specific series of patients: the status of 
oestrogen- and progesterone-receptor $3^{36}$; the occurrence of overexpression of the epidermal growth factor receptor ${ }^{37}$ or the oncogene erbB2 (HER2 or neu) ${ }^{38}$; the extent of cell surface adhesiolysis, detertiined by measuring cathepsin $\mathbb{D}^{39}$; the amount of urinary plasminogen activator ${ }^{40}$; histologic features such as the histologic or nuclear grade ${ }^{41,42}$; cytokinetic parameters and DNA aneuploidy. Other newer, promising prognostic factors, such as heat-shock proteins ${ }^{43}$, nm23 $3^{44}$, collagenase type $\left[\mathrm{V}^{45}\right.$ and erbB $3^{46}$ will require more study. In addition, there is evidence to suggest that the presence of micrometastases in bone marrow detected by monoclonal antibodies ${ }^{47}$ and the presence of new blood vessels in the vicinity of the tumour detected by factor VIII immunohistochemical staining ${ }^{4 / 2}$ or $\mathrm{CD} 34^{49}$ may be useful in assessing prognosis. The studies to date have been too small to evaluate all these prognostic variables simultaneously, leaving clinicians and patients confused on the tests to rely on.

\section{STEROID-RECEPTORS AND PROGNOSIS}

The prognostic significance of steroid-receptor status of the primary breast tumour is still under debate. The prognostic value of oestrogen-receptor (ER) content in tumour tissue with regard to recurrence rate is stronger in studies with relatively short follow-up and in studies in which the estimated disease-free intervals (DFI) were calculated on relatively few recurrences ${ }^{50-59}$.

Studies with more prolonged follow-up times suggest that the favourable effect of ERpositivity on recurrence rate is gradually decreasing in time ${ }^{60.61 .62}$. It has been suggested that the measurement of progesterone-receptor ( $\mathrm{PgR}$ ) content in breast cancer tissue provides information about prognosis with regard to relapse-free survival ${ }^{63,64}$. Other studies, however, do not confirm this correlation ${ }^{65,65}$.

\section{DNA CONTENT AND DNA SYNTHESIS; DNA FLOWCYTOMETRY (FCM)}

The cell cycle can be divided in three periods: the G0/1 phase when the cell contains 2 haploid sets of chromosomes (2 C DNA content), the G2/M phase with a double amount of DNA (4 C DNA content) and the S-phase when a cell is in the proliferative phase with the DNA content varying between $2 \mathrm{C}$ and $4 \mathrm{C}$. The historical consensus from available studies is that duration of the interval of DNA synthesis or S-phase in breast cancer cells is approximately 18 hours, the postsynthetic gap G2 near 4-5 hours, the duration of mitosis 1-2 hours, the G0 resting state and G1 presynthetic gap are variable and the total duration of the cell cycle is $1-4$ days $^{29}$. The cell cycle time, i.e. the time from one mitosis to the next, predicted by Thymidine Labelling Index (TLI), would suggest a mean doubling time for breast cancer to be approximately 12 days assuming no exit from the proliferative compartment ${ }^{67}$. Since actual measured doubling times of breast carcinomas are at least 10 times longer ${ }^{37}$, the losses from the proliferative compartment must be considerable. The most direct measurement of cell proliferation is the mitotic index (MI), which can be measured directly from routine histologic sections. Because the MI of most breast cancers is extremely low, it is very difficult to measure and would require counting more than 50.000 cells. 
The introduction of tritiated thymidine, a precursor for DNA synthesis, enables the S-phase cells to be identified with confidence through the use of autoradiography ${ }^{6}$. The TLI of breast cancer cells is approximately 40 times greater than the MI and can be measured with reasonable accuracy by counting 2000 muclei in an autoradiograph.

The technique of DNA flow cytometry can provide clinicians with two potentially important pieces of infomation. In the first place it gives a measurement of the percentage of cells with a DNA content corresponding with the S-phase of the cell cycle. In the second place it gives information about the presence and degree of abnormal DNA content in the breast cancer cell population. Tubiana and Silvestrini have demonstrated the close correlation between thymidine labelling index (TLI) and clinical outcome in breast cancer patients ${ }^{69: 70,71}$. FCM and TLI appear to provide similar information about the percentage of proliferating cells ${ }^{72}$. Since there is now a technique for obtaining cellular DNA from paraffin-embedded tissue blocks ${ }^{73}$, retrospective analyses regarding the prognostic impact of tumour cell cytokinetics have become possible.

The basic principles of FCM are illustrated in figure 1. Nuclei in liquid suspension are labelled with a fluorescent dye which binds to DNA. These fluorochromated nuclei flow through a narrow orifice allowing only a passage of a single cell and are passed with high velocity through a high intensity light beam which is usually provided by a laser ot high pressure arc lamp. The nuclei passing the light beam are able to excite the dye and to emit a light signal of higher wave length, which is collected in a photo-multiplier tube. This tube converts the light signal in an electric signal, which can be made visible on an oscilloscope or expressed in units on an arbitrary scale. In the final analysis, the amount of dye bound in or to one single cell is translated into the height of an electric pulse.

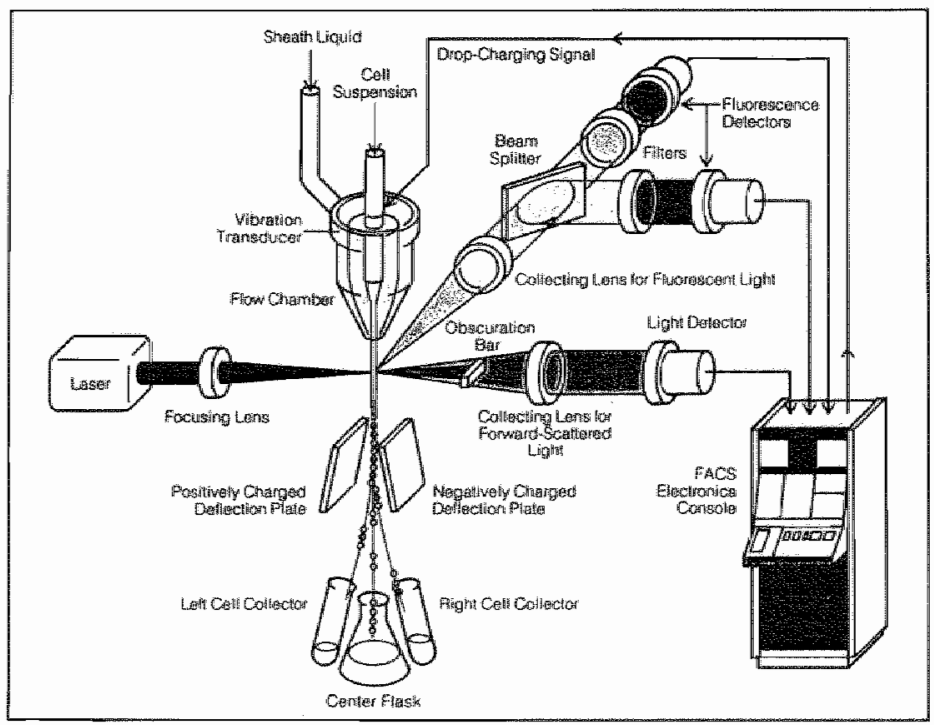

Figure 1 Basic principles of flow cytometry (FCM) by Fluorescent Activated Cell Sorting (FACS). 
FCM can be applied to study all those cellular characteristics which can be lured into the binding of a fluorescent dye. The characteristics may be present on the cell surface or in the cytoplasm. FCM can also be applied in staining nuclear material, in particular chromosomal DNA. The DNA histogram reflects a frequency distribution of cells containing a particular amount of DNA. As a consequence, the percentage of cells in the three different phases can be calculated from the DNA histogram.

The measurement of total nuclear DNA content is one of the oldest applications of FCM. For this purpose, nuclei must be stained in suspension with a fluorescent dye that binds specifically and stoichiometrically to DNA, e.g. propidium iodide or DAPI. Cells in tissues must first be disaggregated to obtain a monodisperse suspension that can be measured by FCM. The quality of the measurements depends critically on the quality of the nuclear suspension. Debris particles and unequal uptake of dye in mechanically or chemically damaged nuclei interfere with the resolution of the measurements. Cell preparation procedures for fresh or frozen tissues based on mild enzymatic digestion and treatment with non-ionic detergents such as widely used detergent-trypsin procedure developed by Vindel $\phi \mathrm{v}$ et al. have proved to routinely yield high quality DNA distributions for a wide variety of tissues ${ }^{74}$. This method, however, permits only prospective studies on fresh or frozen tissue samples. This situation has changed with Hedley et al. introducing the pepsin-digestion technique to render archival paraffinembedded tissue blocks accessible to FCM analysis ${ }^{22.75,76}$. Since the introduction of this technique, a number of clinical studies have been published on the prognostic value of DNA ploidy in a great variety of human tumours. This method has an undeniable role in evaluating the clinical behaviour of tumours with DNA content aberrations. However the usually lower resolution of DNA histograms based on deparaffinized samples may eventually limit the contribution of studies on paraffin specimens ${ }^{77}$.

Most groups use the admixed non-neoplastic stromall cells and leucocytes present in most solid tumours as an internal ploidy reference. The position of the DNA diploid cell population in fresh or frozen material can be verified by adding trout or chicken erythrocyte nuclei ${ }^{78}$. This method cannot be applied to deparaffinized samples, due to differences in dye uptake between standard cells and cells from formalin-fixed tumour tissue ${ }^{79}$.

The S-phase fraction (SPF) cannot be calculated in a considerable percentage of DNA histograms of tumour samples. Tumours with hypodiploid DNA content as well as low DNA aneuploid (DNA $<1.15$ ) and multiploid tumours are not suitable for SPF determination ${ }^{80,81}$ and can introduce a bias in the evaluation of correlation between SPF and prognosis ${ }^{81}$.

Proliferating non neoplastic cells have in general a lower SPF value than malignant cells causing an underestimation of SPF in DNA diploid or low DNA aneuploid tumours ${ }^{81.82}$. Another pitfall in SPF determination is cell debris arising during the preparation of tumour material for FCM measurements or due to tumour necrosis which causes artificially high SPF values. SPF measurements particularly from paraffin-embedded material should therefore be evaluated with reserve ${ }^{83}$ especially if the SPF results will affect the choice of therapy ${ }^{81}$. This is also true if computer programs are used to solve some of the problems mentioned ${ }^{84,85}$. 


\section{PROBLEMS IN FCM INTERPRETATION}

Abnormal DNA content of cells can be identified by FCM when the total abnormal cellular DNA content exceeds $5 \%$ of total DNA, depending on the ratio of normal to abnormal cells and the resolution of the DNA histogram. In contrast to karyotyping, balanced chromosomal translocations and small deletions or amplifications cannot be detected by FCM.

The interpretation of DNA histograms is usually not difficult. Caution is required if artifactual $\mathrm{G} 0 / \mathrm{G} 1$ peaks are identified, caused by improper preparation. Especially in paraffin-embedded tissues, necrosis can be a potential source of false aneuploid DNA peaks ${ }^{86}$. The resolution of a DNA histogram in discriminating between diploid and aneuploid cells depends on the quality of the individual peaks, which should be narrow and non-skewed. This peak quality is usually expressed as the coefficient of variation (CV) according to the equation:

$\mathrm{CV}=(100 \times \mathrm{FWHM}) /(2.35 \times$ peak channel $)$, in which FWHM is the width of the peak at half-maximum. The $\mathrm{CV}$ depends primarily on the quality of the nuclear suspensions, the staining condition and the optical system of the flow cytometer. In case of a low CV or a $\mathrm{CV}>3 \%$ with a perfectly symmetrical curve the possibility of a single cell population is high. If the curve is skewed, the possibility of overlapping cell populations is high. Difficulties in interpretation can be overcome by techniques using monoclonals or light scattering properties which permits selective measurement of subgroups ${ }^{87} .88$. Hedley"s suggestion to omit measurement if the $\mathrm{CV}$ of a DNA stemline in the region if DNA index $(\mathrm{DI})=1.00$ exceeds $5.5 \%$ is followed in most institutes ${ }^{73,75}$. These tumours are classified as a separate entity.

A tetraploid tumour cell population, overlapping the G2M peak of the normal cells is difficult to diagnose. If the tetraploid tumour cell population is accompanied by its own G2M compartment, the problem is easily solved. Beerman et al. suggested to apply a cut off point of $20 \%$ for the size of the G2M fraction to discriminate such peaks from a DNA diploid G2M compartment ${ }^{89}$.

Hypodiploidy is a clinically important phenomenon since loss of genetic material is recognized as a contributing cause to malignant progression. Thus, cells with less than normal DNA may be of clinical importance probably because they may have a high S-phase fraction (SPF) $)^{90,91}$.

In fresh or frozen tumour samples the position of the diploid DNA peak can be marked by using ploidy reference cells, a method that can not be applied to the examination of paraffin-embedded materials. In this material the most left peak is generally considered to be the diploid DNA peak. A possible method to identify a hypodiploid fraction in deparaffinized tumour samples is to compare the area under the two G0/1 peaks with the estimated proportion of tumour cells in histological control sections ${ }^{89}$. This approach is only applicable if the two G0/1 peaks are sufficiently separated. The reported incidence of hypodiploidy in human breast carcinomas varies between $3-10 \%{ }^{80.9 !}$.

Deviations in cellular DNA content (aneuploidy) were expressed as DNA index. (DI). The DI was calculated as the ratio of aneuploid to diploid G1/G0 peak channel; in case of $\geq 2$ peaks the left sided was always considered as diploid. 


\section{FLOW CYTOMETRY AND CLINICAL VARIABLES}

\section{DNA Content in Malignant Breast Lesions}

The majority of breast cancer specimens show one or more aneuploid stem lines. In the literature the percentage of cases with aneuploidy ranges between $40 \%$ and $89 \%$ \%2:-100\% These diverging results can be explained by the use of different interpretations of the DNA ploidy pattern. Another possibility can be misinterpretation due to the analysis of limited numbers of nuclei from the same tumour, obscuring intra-tumour heterogeneity.

\section{DNA Ploidy and SPF}

SPF determined by flow cytometry has a wide range in human breast cancer with median values between 5 and $15 \%$ in the majority of the reported studies. Most studies show a correlation between SPF and DNA ploidy with DNA aneuploid breast tumours having significantly higher SPF than DNA diploid tumours ${ }^{82,101-104}$. However, McDivitt et al. ${ }^{105}$ could not confirm this correlation and many clinical studies concerning FCM in breast cancer patients did not mention the possibility of a correlation.

\section{Correlation between Histological Types and FCM Parameters}

The literature pays moderate attention to ploidy and histological types of breast cancer. Medullary carcinomas are frequently aneuploid whereas tubular, lobular and mucinous carcinomas are mostly diploid.

A good correlation is described between grading and DNA ploidy ${ }^{106-110}$ (page 11).

\section{Correlation between Tumour Size and FCM Parameters}

No consensus has been reached with respect to correlation between DNA ploidy and T-status. A number of studies have shown a clear correlation of DNA aneuploidy and increasing size of the primary breast tumour ${ }^{94,95,100,110-113}$. Not all authors, however, could confirm this correlation ${ }^{95,109,114-116}$.

Tumour size and SPF are not equivocally related to each other. Some authors did find a correlation ${ }^{93,100,115}$ while most authors did not ${ }^{81,102,10 \%, 117}$,

\section{FCM Parameters and Nodal Status}

There is disagreement in the literature with respect to correlation between DNA index and nodal status. Some found a correlation between nodal status and ploidy ${ }^{84,109,118}$ whereas most authors did not find a correlation ${ }^{93,95,95,111,117}$. Arnerløv et al. described a correlation between ploidy and axillary nodal status if perinodal growth was seen around the tumour containing lymph nodes ${ }^{107}$.

With respect to SPF most investigators did not find a difference in SPF between node-negative and node-positive patients ${ }^{50,72.102,109.13,117,119}$. Only Koike et al. ${ }^{115}$ described a correlation between proliferation index and lymph node invoivement. The mean proliferation index was significantly higher in patients with more than 4 axillary nodes involved in comparison with no nodal involvement. There is one report of lower SPF values for diploid tumours in node-negative breast cancer patients when compared to SPF values in diploid node-positive tumours ${ }^{82}$. 


\section{FCM Parameters and Histological Grading}

Well differentiated tumours are mostly diploid whereas poorly differentiated tumours

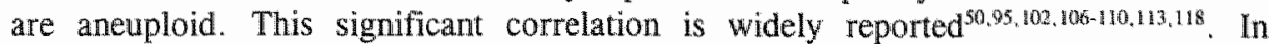
histologically low grade tumours lower SPF values are described in comparison with high grade breast carcimomas ${ }^{81.99,101,108.109 .167}$.

\section{FCM Parameters and Steroid-Receptor Status}

In general, a higher frequency of aneuploidy is described in ER-negative breast cancers ${ }^{94,95.100 .1099 .114}$. However, this correlation was not always significant. StuartHarris et al.(1985) described a weak relationship between ER and DFI ${ }^{120}$ whereas many authors could not find a correlation at all14,105,145,116,119,121,122. Although less attention has been paid to the relationship between PgR and DNA ploidy the results appear similar to those with ER-status ${ }^{95,109,115,116,122}$.

Equivocal relationship between SPF values and ER-status has been reported. Significantly higher SPF values in ER-negative tumours have been described ${ }^{85,95,105,113,115}$ but other investigators could not find a correlation between SPF values and ER-status ${ }^{115,119}$. The same lack of correlation has been described between SPF values and PgR-status.

\section{FLOW CYTOMETRIC PARAMETERS AND PROGNOSIS OF BREAST CANCER}

\section{DNA Ploidy}

A complicating factor in comparing studies on the prognostic value of DNA-ploidy consists of heterogeneity of the investigated populations and differences in duration of follow-up. The majority of investigators have reported a positive correlation between DNA diploidy and a longer OS and/or DFS $81,91,93,94,100,101,104,107,110-112,117,121,123,124$. Other investigators, however, have failed to detect a significant relationship between DNA ploidy and DFS or $\mathrm{OS}^{94,115,120,125}$. A number of studies in node-negative breast cancer did not show a significant influence of DNA ploidy on survival ${ }^{94.126,127}$ whereas other studies

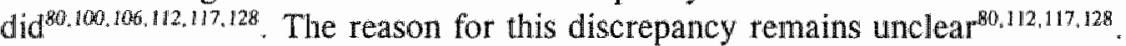

\section{$S P F$}

Most studies have shown a good correlation between SPF and disease-free and/or overall survival ${ }^{80,81,101-103,115-117,129}$. However, SPF does not always appear to be an independent prognostic factor. Sometimes, SPF was lost in multivariate analysis when histological grading was introduced in the analysis ${ }^{102.117}$. In a multivariate analysis done by Clark et al. for node-negative diploid breast tumours, SPF was the only independent significant predictor of DFS and OS. The classical prognostic factors such as ER-status, age and T-status, did not affect the prognosis beyond the SPF effect in this type of breast cancer patients ${ }^{80}$. However, Clark's conclusions were based on very few events in both the low and high SPF groups.

In node-negative DNA aneuploid tumours SPF does not reach that high predictive value as in DNA diploid tumours ${ }^{30,103}$.

Sigurdsson et al. reported SPF to have a major prognostic impact in multivariate analysis in diploid as well as aneuploid node-negative populations ${ }^{129}$. 
In node-positive breast cancer patients Hedley et al. described a shorter DFS in patients with SPF $>10 \%$, but SPF was not an independent prognostic factor ${ }^{83}$.

\section{INTRA-TUMOUR HETEROGENEITY}

Intra-tumour heterogeneity in breast cancer has been investigated in a limited number of studies. Assessment of heterogeneity can be of importance since it might be the explanation for the discrepancy between studies regarding the prognostic value and limit the clinical applicability of this technique.

Hitchcock et al. have described $33 \%(8 / 24)$ heterogeneity of DNA ploidy when 3 tissue blocks of the same primary breast tumour was analyzed. When DNA ploidy from metastases was analyzed of the remaining 16 homogenous tumours, 6 of 16 showed heterogeneity in the metastases ${ }^{130}$. In two studies it is indicated that undersampling could lead to underestimation of intra-tumour heterogeneity ${ }^{130-132}$. Beerman et al. ${ }^{132}$ found stemline heterogeneity in $27 / 44(61 \%)$ of the primary tumours when the data of the separate samples (mean 4.9) were pooled. It is therefore quite clear, that the chance of finding ploidy abnormalities, apart from being dependent on the presence and relative frequency of abnormal stemlines, is also dependent on the degree of sampling.

\section{DEGREE OF CONCORDANCE OF DNA PLOIDY BETWEEN PRIMARY TUMOURS AND THEIR METASTASES}

There is a high percentage of agreement in the literature (74-90\%) in DNA ploidy status between primary tumours and their metastases in the literature ${ }^{96,133,134}$. In two recent studies a concordancy in DNA index between the primary tumour and nodal metastases of respectively 56 and 74 percent of the cases is described ${ }^{130,132}$. As expected the degree of concordance is also dependent on the extent of sampling in both the primary tumour and the metastases. The relative stability in DNA index is also supported by FCM studies in which sequential biopsies were taken from the primary tumour. No changes in DNA index during intervals of several weeks to eight months were observed ${ }^{135.136}$. However, discordancy in DNA ploidy value between primary breast cancer and lymph node metastases have been described as well ${ }^{96,130,131,133}$. It is not clear whether such discordancy reflects clonal selection processes towards certain types of ploidy abnormalities.

The SPF values in primary tumours and metastases are equal in approximately $2 / 3$ of the cases and the mean SPF values do not differ significantly ${ }^{133,134}$. 


\section{THIS THESIS}

The work, described in this thesis, sought to contribute to the treatment of patients with primary breast cancer in two ways: by evaluating a combined adjuvant treatment with chemotherapy and a progestagen and by evaluating the prognostic impact of steroidreceptors and DNA FCM derived parameters in a large and homogeneously treated cohort of patients.

In the first part of this thesis, we sought to determine, whether the addition of hormonal treatment with high dose progestagen to adjuvant chemotherapy would improve the prognosis of patients with axillary node-positive primary breast cancer. These patients were part of a large cohort of primary breast cancer patients seen in the South-Eastern Netherlands during a period of 5 years. Premenopausal and postmenopausal women younger than 71 years were treated surgically and selectively with irradiation. Nodepositive patients were post-operatively treated with chemotherapy (cyclophosphamide, doxorubicin and 5-fluorouracil) every 4 weeks for 6 months. These patients were randomized into two arms A: no concomitant progestagen and B: concomitant medroxyprogesterone acetate intramuscularly. Endpoints of the clinical study were: disease-free survival (DFS), survival to locoregional relapse, to distant metastases and overall survival (OS)(chapter II and IIa).

This cohort, that is unselected and treated according to this well defined protocol, was also used to investigate the importance of a number of potentially useful prognostic factors. A number of clinical variables were investigated such as: age, oestrogen and progesterone-receptor content, tumour stage (TNM classification) and the number of tumour containing axillary nodes. The prognostic significance of steroid-receptor activity has been studied on 329 node-negative and 320 node-positive patients (see chapter IV). In addition to clinical parameters and steroid-receptor content, special attention was paid to parameters associated with nuclear DNA-content and proliferation. Flow cytometric DNA determination was performed on nuclei isolated from formalin fixed paraffin embedded tumour containing tissue blocks. First, the prognostic significance of DNAcontent and S-phase fraction in 329 node-negative and 320 node-positive patients was analyzed and described in chapter IV and chapter V, and subsequently DNNA content and the percentage of proliferating cells of primary tumours and their nodal metastases have been examined (chapter VI). 


\section{REFERENCES}

1 Muir C, Waterhouse J, Mack T, Powell $I$, Whelan $S$, eds. Cancer incidence in five continents. Vol. 15. Lyon, France: International Agency for Research on Cancer, 1987 (LAC Scientific Publications no.88).

2 National Center for Health Statistics. Vital statistics of the United States, 1987, vol.2. Mortality, Part A. Washington D.C. Government Printing Office 1990 (DHHS publication no (PHS) 90-1101).

3 Coebergh JWW. Incidence and prognosis of cancer in the Netherlands: studies based on cancer registries. Thesis 1991, ISBN 90-9004143-5.

4 Moolgavkar S, Day NE, Stevens RG. Two stage model for carcinogenesis: epidemiology of breast cancer in females. J Natl Cancer Inst 1989; 65: 559-569.

5 Armstrong B, Doll $R$. Environmental factors and cancer incidence and mortality in different countries, with special reference to dietary practices.

Int J Cancer 1975; 15:617-631.

6 Boyle $\mathrm{P}$, Maisoneuve P, Hsieh C. Epidemiology of breast cancer. In: Zatonski W, Boyl $P$, Tyczynski $J$, eds. Cancer prevention: wital statistics to prevention: Proceedings of the International Conference, Warsaw, Poland, October 12-14, 1988. Warsaw, Poland: P..A. Interpress, 1990: 128-135.

7 Prentice $\mathbb{R L}$, Sheppard $\mathbb{L}$. Dietary fat and cancer: consistency of the epidemiologic data and disease prevention that may follow from practical reduction in fat consumption. Cancer Causes Control 1990; 1:253.

8. Otman R, Pike MC, King M-C, Henderson BE, Practical guide for estimating risk for familial breast cancer. Lancet $1983 ; 2: 556-558$.

9 Anderson DE. Genetic study of breast cancer: identification of a high risk group. Cancer 1974; $34: 1090-1097$.

10 Black DM, Solomon E. The search for the familial breast/ovarian cancer gene.

Trends in Genetics 1993; 9: 22-26.

11 Futreal PA, Liu Q, Shattuck-Eidens et al. BRCA $A_{\mathbb{1}}$ mutations in Primary Breast and ovarian carcinomas. Science 1994; 266: 120-122.

12 Staging for carcinoma of the breast. In: Beahrs O, Henson D, Hutter R, Myers eds. Manual for staging of cancer. 3rd ed. Philadelphia J.B. Lippincott 1988: 145-150.

13 Bonadonna $G$, Brusamolino $E$, Valagussa $P$ et al. Combination chemotherapy as an adjuvant treatment in operable breast cancer. $\mathrm{N}$ Engl J Med 1976; 294: 405-410.

14 Fisher B, Carbone $\mathbb{P}$, Economou $S G$ et al. I-Phenylalanine mustard (L-PAM) in the management of primary breast cancer: a project of early findings.

N Engl J Med 1975; 292: 117-122.

15 Controlled trial of tamoxifen as single adjuvant agent in the management of early breast cancer: analysis at six years, by Nolvadex Adjuvant Trial Organization.

Lancet $1985 ; 1: 836-840$.

16 Controlled trial of tamoxifen as a single adjuvant agent in the management of early breast cancer: analysis at eight years by Nolvadex Adjuvant Trial Organization.

Br J Cancer 1988; 57: 608-611.

1.7 Fislier B, Redmond $C$, Legault-Poisson $S$ et al. Postoperative chemotherapy and tamoxifen compared with tamoxifen alone in the treatment of node-positive breast cancer patients aged 50 years and older with tumours responsive to tamoxifen: results from the National Surgical Adjuwant Breast and Bowel Project B-16. J Clin Oncol 1990; 8: 1-14. 
18 Rivkin S, Green S, Metch B et al. Adjuvant combination chemotherapy (CMFVP) vs tamoxifen (TAM) versus CMFVP + TAM for postmenopausal women with $\mathrm{ER}+$ operable breast cancer and positive axillary lymph nodes: an intergroup study.

Proc Am Soc Clin Oncol 1990; 9: 24.

19 Early Breast Cancer Trialists' Collaborative Group. Systemic treatment of breast cancer by hormonal, cytotoxic, or immune therapy: 133 randomized trials involving 31.000 recurrences and 24.000 deaths among 75.000 women. Lancet $1992 ; 339: 1-15,71-84$.

20 National Institute for Health Consensus Conference Treatment of early stage breast cancer. JAMA 1991; 265: 391-395.

21 Consensus Conference: Adjuvant chemotherapy for breast cancer. JAMA $1985 ; 254: 3461-3463$.

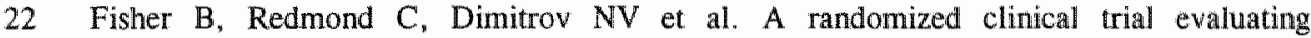
sequential methotrexate and fluorouracil in the treatment of patients with node-negative breast cancers who have oestrogen-receptor-negative tumours.

N Engl J Med 1989; 320: 473-478.

23 Fisher $B$, Constantino $J$, Redmond $C$ et al. A randomized clinical triall evaluating tamoxifen in the treatment of patients with node-negative breast cancers who have oestrogen-receptor-positive tumours. N Engl J Med 1989; 320: 479-484.

24 Mansour EG, Gray R, Shatila $\mathrm{AH}$ et al. Efficacy of adjuvant chemotherapy in high-risk node-negative breast cancer patients: an intergroup study.

N Engl J Med 1989; 320: 485-490.

25 The Ludwig Breast Cancer Study Group. Prolonged disease-free survival after one course of perioperative adjuwant chemotherapy for node-negative breast cancer.

N Engl J Med 1989; 320: 491-496.

26 Canellos GP, DeVita VT, Gold GL et al. Combination chemotherapy for advanced breast cancer: response and effect on survival. Ann Intern Med 1976; 84: 389-392.

27 Falkson G, Gelman RS, Tormey DC et al. The Eastern Cooperative Oncology Group experience with cyclophosphamide, adriamycin, and 5-fluorouracil (CAF) in patients with metastatic breast cancer. Cancer 1985; 56: 219-224.

Tormey DC, Gelman RS, Band PR et al. Comparison of induction chemotherapies for metastatic breast cancer: an Eastern Cooperative Oncology Group trial.

Cancer 1982; 50: $1235-1244$.

29 Powles TJ, Smith IE, Ford HT et al. Fallure of chemotherapy to prolong survival in a group of patients with metastatic breast cancer. Lancet $1980 ; 1: 580-582$.

30 Brambilla C, Valagussa P, Bonadonna G. Sequential combination chemotherapy in advanced breast cancer. Cancer Chemotherapy Pharmacol 1978; 1: 35-39.

31 Lippmann ME, Cassidy J, Wesley M. A randomized attempt to increase the efficacy of cytostatic chemotherapy in metastatic breast cancer by hormonal synchronisation.

J Clin Oncol $1984 ; 2: 28-36$.

32 Henderson IC, Hayes DF, Come $S$. New agents and new medical treatments for advanced breast cancer. Semin Oncol 1987; 14: 34-36.

33 Harris JR, Hellman S, Henderson IC, Kinne DW. Breast diseases. 2nd ed: JB Lippincott, 1991 .

34 Fisher $B$, Bauer $M$, Wickerham $D L$ et al. Relation of number of positive axillary nodes to the prognosis of patients with primary breast cancer; an NSABP update.

Cancer 1983; 52: 1551-1557.

35 Carter $C L$. Allen $C$. Henson $\mathbb{D E}$. Relation of tumour size, lymph node status and survival in 24.740 breast cancer cases. Cancer 1989; 63:181-187. 
36 Fisher $B$, Redmond $C$, Fisher ER, Caplan R. Relative worth of oestrogen or progesterone-receptor and pathologic characteristics of differentiation as indicators of prognosis in node-negative breast cancer patients: findings from National Surgical Adjuvant Breast and Bowel Project Protocol B-06. J Clin Oncol 1988; 6: 1076-1087.

37 Sainsbury JRC, Farndon JR, Needham GK et al. Epidermal-growth-factor receptor status as predictor of early recurrence and death from breast cancer.

Lancet 1987; 1: 1398-1402.

38 Seamon DJ, Clark GM, Wong SG et al. Human breast cancer: correlation of relapse and survival with amplification of the HER-2/neu oncogene. Science $1987 ; 235: 177-182$.

39 Thorpe SM, Rochefort H, Garcia M et al. Association between high concentrations of $\mathrm{Mr}$ 52.000 cathepsin $\mathrm{D}$ and poor prognosis in primary turnan breast cancer.

Cancer Res 1989; 49: 6008-6014.

40 Schmiti $M$, Janicke $F$, Graeff $H$. Tumour-associated fibrinolysis: the prognostic relevance of plasminogen activators UPA and $\mathrm{PPA}$ in human breast cancer.

Blood Coagul Fibrinolysis 1990; 1 : 695-702.

41 Fisher ER, Gregorio RM, Fisher B et al. The pathology of invasive breast cancer: a syllabus derived from findings of the National Surgical Adjuvant Breast Project Protocol no.4. Cancer $1975 ; 36: 1-85$.

42 Singh $L$, Wilson $A J$, Baum $M$ et al. The relationship between histological grade, oestrogen-receptor status, events and survival at 8 years in the NATO (Nolvadex) trial. Br J Cancer 1988; 57: 612-614.

43 Thor A, Benz C, Moore D II et al. Stress response protein ( $\operatorname{sip}-27$ ) determination in primary human breast carcinomas: clinical, histologic and prognostic correlations.

J Natl Cancer Inst 1991; 83: 170-178.

44 Bevilacqua G, Sobel ME, Liotta LA, Steeg PS. Association of low nm23 RNA levels in human primary infiltrating ductal breast carcinomas with lymph node involvement and other histopathological indicators of high metastatic potential.

Cancer Res $1989 ; 49: 5185-5190$.

45 Monteagudo C, Merino MJ, San-Juan J et al, Immunohistochemical distribution of type IV collagenase in normal, benign and malignant breast tissue.

Am J Pathol 1990; 136: 585-592.

46 Di Fiore $P$, Kraus $M$. Mechanisms involving and expanding erbB/EGF receptor family of tyrosine kinases in human neoplasia. In: Dickson $R B$, Lippman $M E$, eds. Gene, oncogenes, and hormones, Boston: Kluwer Academic (in press).

47 Cote $\mathbb{R J}$, Rosen PP, Lesser ML et al. Prediction of early relapse in patients with operable breast cancer by detection of occult bone marrow metastases.

$J$ Clin Oncol 1991; 9: 1749-1756.

48 Weidner $N$, Semple $\mathrm{JP}$, Welch WR, Folkman J. Tumour angiogenesis and metastasis correlation in invasive breast carcinoma. N Engl J Med 1991; 324: 1-8.

49 Horak E, Leek R, Klenk $N$ et al. Angiogenesis " assessed by platelet/endothelial cell adhesion molecule antibodies, as indicator of node metastases and survival in breast cancer. Lancet 1992; 340: 1120-1124.

50 Chevalier B, Heintzmann F, Mosseri V et al. Prognostic value of oestrogen and progesterone-receptor in operable breast cancer. Results of univariate and multivariate analysis. Cancer $1988 ; 62 / 12: 2517-2524$.

51 Knight WA III, Livingston RB, Gregory EJ, McGuire WL. Oestrogen-receptor as an independent prognostic factor for early recurrence of breast cancer.

Cancer Res 1977: 37: 4669-4674. 
52 Rich MA, Furmanski P, Brooks SC and the Breast Cancer Prognostic Study Surgery and Pathology Associates: Prognostic value of oestrogen-receptor determinations in patients with breast cancer. Cancer Res 1978; 38: 4296-4298.

53 Allegra JC, Lippman ME, Simon R et al. Association between steroid hormone receptor status and disease free interval in breast cancer. Cancer Treat Rep 1979; 62: 1271-1277.

54 Osborne CR, Yochmowitz MG, Knight WA III, McGuire WL. The value of oestrogen and progesterone-receptors in the treatment of breast cancer.

Cancer $1980 ; 46: 2884-2888$.

55. Blamey RW, Bishop HM, Blake JRS et al. Relationship between primary breast cancer, tumour receptor status and patient survival. Cancer 1980; 46: 2765-2769.

56 Valagussa $P$, DiFronzo $G$, Bignami $P$ et al. Prognostic importance of oestrogen-receptors to select node-negative patients for adjuvant chemotherapy. In: Salmon SE; Jones $\mathrm{SE}$ (eds): Adjuvant therapy of Cancer III. Grune and Stratton, New York, 1981, pp.329-333.

57 Crowe JP, Hubay CA, Pearson $\mathrm{OH}$. Oestrogen-receptor status as a prognostic indicator for stage I breast cancer patients. Breast Cancer Res Treat 1982; 2: 171-176.

58 Raemaekers JMH. Prognostic significance of estradiol and progesterone-receptor activities in human breast cancer. Thesis 1987, p.52-64.

59 Clark GM, McGuire WL, Hubay CA et al. Progesterone-receptors as a prognostic factor in stage II breast cancer. New Engl J Med 1983; 309: 1343-1347.

60 Hähnel $R$, Woodings $T$, Vivian $A B$. Prognostic value of oestrogen-receptors in primary breast cancer. Cancer 1979; 44:671-675.

61 Furmanski $\mathrm{P}$, Saunders $\mathrm{DE}$, Brooks SC, Rich NA and the Breast Cancer Prognostic Study Clinical and Pathology Associates: The prognostic value of oestrogen-receptor determinations in patients with primary breast cancer: an update.

Cancer 1980; 46: 2794-2796.

62 Saez S, Cheix F, Asselain B. Prognostic value of oestrogen and progesterone-receptors in primary breast cancer. Breast Cancer Res Treat 1983; 3: 345-354.

63 Pichon MF, Pallud C, Brunet M, Milgrom $\mathbb{E}$. Relationship of presence of progesteronereceptors to prognosis in early breast cancer. Cancer Res 1980; 40; 3357-3360.

64 Clark GM, McGuire WL, Hubay CA, Pearson OH, Marshall IS. Progesterone-receptor as a prognostic factor in stage II breast cancer. N Engl J Med 1983; 309: 1343-1347.

65 Howell A, Horland RNL, Bramwell VHC, Svindell R, Barnes DM, Redford J, Wilkinson MJS, Crowther D, Sellwood RA. Steroid-hormone receptors and survival after first relapse in breast cancer. Lancet 1984 ; $\mathrm{i}$ : $588-591$.

66 Howat JMT, Harris M, Svindell R, Barnes DM. The effect of oestrogen and progesterone-receptors on recurrence and survival in patients with carcinoma of the breast.

Br J Cancer 1985; $51: 263-270$.

67 Meyer JS. Growth and cell measurements in human tumours.

Pathol Annu 1981; 16:53-81.

68 Taylor $\mathrm{JH}$, Woods PS, Hughes WL. The organization and duplication of chromosomes using tritium-labelled thymidine. Proc Natl Acad Sci SUA 1957; 43: 122-128.

69 Tubiana M. Pejovic MJ, Renaud A et al. Kintetic parameters and the course of the disease in breast cancer. Cancer 1981; 47: 937-943.

70 Tubiana $\mathrm{M}$, Pejovic $\mathrm{MH}$, Chavaudra $\mathrm{N}$ et al. The long-term significance of thymidine labelling index in breast cancer. Int J Cancer 1984; 33:441-445.

71 Silvestrini $R$, Daidone $M G$, Gasparini $G$. Cell kinetics as a prognostic marker in nodenegative breast cancer. Cancer 1985; 56: 1982-1987.

72 McDivitt RW, Stone KR, Meyer JS. A method for dissociation of viable human breast cancer cells that produces flow cytometric kinetic information similar to that obtained by thymidine labelling. Cancer Res 1984; 44: 2628-2633. 
73 Hedley DW, Friedlander ML, Taylor IW el al. Method for analysis of cellular DNA content of paraffin-embedded pathological material using flow cytometry.

J Histochem Cytochem 1983; 31: 1333-1335.

Vindeldv LL, Christensen IJ and Nissen NI. A detergent-trypsin method for preparation of nuclei for flow cytometric DNA analysis. Cytometry $3: 323-327,1983$.

Hedley DW. Flow cytometry using paraffin-embedded tissue: five years on.

Cytometry $1989 ; 10: 229-241$.

76 Schutte B, Reynders MMJ, Bosman FT, Blijham GH. Flow cytometric determination of DNA ploidy level in nuclei isolated from paraffin embedded tissue.

Cytometry $1985 ; 6: 26-30$.

77 Vindeldv LL and Christenssen IJ. A review of techniques and restilts obtained in one laboratory by an integrated system of methods designed for routine clinical flow cytometry DNA analysis. Cytometry 1990; 11:753-770.

Vindel $6 \mathrm{v}$ LL. Christenssen IJ, Jensen $G$ and Nissen NI. Limits of detection of nuclear DNA abnormalities by flow cytometric DNA analysis. Cytometry 1983; 3: 332-339.

Schutte B, Reynders MMJ, Bosman FT and Blijham GH. Flow cytometric determination of DNA ploidy level in nuclei isolated from paraffin-embedded tissue.

Cytometry $1985 ; 6: 26-30$.

80 Clark GM, Dressler LG, Owens MA, Pounds G, Oldaker T and McGuire WL. Prediction of relapse or survival in patients with node-negative breast cancer by DNA flow cytometry. N Engl J Med 1989; 320: 627-633.

81 Hedley DW, Rugg CA and Gelber RD. Association of DNA index and S-phase fraction with prognosis of node-positive early breast cancer. Cancer Res 1987; 47: 4729-4735.

82 Dressler LG, Seamer L, Owens MA, Clark GM and McGuire WL. DNA flow cytometry and prognostic factors in 1331 frozen breast cancer specimens.

Cancer $1988 ; 61: 420-427$.

83 Moran RE, Black MM, Alpert L and Straus MJ. Correlation of cell cycle kinetics, hormone receptors, histopathology and nodal statas in human breast cancer.

Cancer $1984 ; 54: 1586-1590$.

84 Baldetorp B, Dalberg $M$, Holst $U$ and Lindgren $G$. Statistical evaluation of cell kinetic data from DNA flow cytometry (FCM) by the EM algorithm.

Cytometry 1989; 10: 695-705.

85 Dressler LG, Seamer L, Owens MA, Clark GM and McGuire WL. Evaluation of a modeling system of S-phase estimation in breast cancer by flow cytometry.

Cancer Res 1987; 47: 5294-5302.

86 Joensuu $H$, Alanen KA, Kleni PJ and Aine R. Evidence for false aneuploid peaks in flow cytometric analysis of paraffin-embedded tissue. Cytometry 1990; 11:431-437.

87 Feitz WFJ, Beck HLM, Smeets AWGB et al. Tissue-specific markers in flow cytometry of urologicall cancers: cytokeratins in bladder carcinoma. Int J Cancer $1985 ; 36: 349-356$.

88 Ramaekers FCS, Beck HLM, Feirz WFJ et al. Application of antibodies to intermediate filament proteins as tissue specific probes in the flow cytometric analysis of complex tumours. Anal Quant Cytol Histol 1986; 8: 271-280.

89 Beerman H. Analytic cytology of breast cancer. Thesis, Leiden, p. 16, 1991

90 Harris $\mathrm{H}$. The analysis of malignancy by cell fusion: the position in 1988 .

Cancer Res 1988; 48: 3302-3306.

91 Coulsen PB, Thornthwaite JT, Woolley TW, Sugarbaker EV and Seckinger D. Prognostic indicators including DNA histogram type, receptor content and staging related to human breast cancer surwival. Cancer Res 1984; 44: $4187 \cdots 4196$.

92 Fallenius AG, Auer GU, Carstensen JM. Prognostic significance of DNA measurements in 409 consecutive breast cancer patients. Cancer 1984; 5: 71-80. 
93 Ewers SB, Langström $\mathrm{E}_{n}$ Baldetorp $\mathrm{B}$, Eillander $\mathrm{D}$. Flow cytometric DNA analysis in primary breast carcinomas and climicopathological correlations.

Cytometry $1984 ; 5: 408-419$.

94 Cornelisse CJ, van de Velde CJH, Caspers RJC, Molenaar AJ, Mermans Y. DNA ploidy and survival in breast cancer patients. Cytometry 1987; 8:225-234.

95 Kalloniemi OP, Hietanen T, Mattila J, Lelitinen M, Lauslahti $K$, Kaivula T. Aneuploid DNA content and high $S$-phase fraction of tumour cells are related to poor prognosis in patit'ats with primary breast cancer. Eur J Cancer Clin Oncol 1987; 23: 277-282.

96 Del Bino $G$, Silvestrini $R$, Zucconi MR, Marchese $G$, Valentinis B, Di Fronzo $G$, Andreola S. DNA ploidy of human breast cancer. Analyt Cell Pathol 1989; $1: 215-223$.

97 Harvey J, de Klerk N, Berryman I, Sterret G, Byme M, Papadimitriou J. Nuclear DNA content and prognosis in human breast cancer: a static cytophotometric study.

Breast Cancer Res Treat 1987; 9: 101-109.

98 Meyer JS, McDivitt RW, Stone KR, Prey MU, Bauer WC. Practical breast carcinoma, cell kinetics: review and update. Breast Cancer Res Treat 1984; 4: 79-88.

99 Falkmer UG, Hagmar T, Auer GU. Efficacy of combined image and flow cytometric DNA assessments in human breast cancers. A methodologic study based on a routine histopathologic material of 2.024 excised tumour specimens.

Analytical Cellular Pathology 1990; 2 (5): 297-312.

100 Beerman $\mathrm{H}$, Kluin PhM, Hermans J, van de Velde $\mathrm{CJ}$, Cornelisse $\mathrm{Cl}$. Prognostic significance of DNA ploidy in a series of 690 primary breast cancer patients.

Int J Cancer 1990; 45: 34-39.

101 Eskelinen MJ, Pajarinen P, Collan Y, Pesonen E, Alhava E, Kettunen K, Nordlling S. Relationship between DNA ploidy and survival in patients with primary breast cancer.

Br J Surg 1989; 76: 830-834.

102 O"Reilly SM, Camplejohn RS, Barnes DM, Millis RR, Allen D, Rubens RD, Richards MA. DNA index, S-phase fraction, histological grade and prognosis in breast cancer.

Br J Cancer 1990; 61: 671-674.

103 Windester DJ, Duda RB, August CZ, Goldschmidt RA, Wruck DM, Rademaker AW, Winchester DP, Merkel DE. The importance of DNA flow cytometry in node-negative breast cancer. Arch Surg 1990; 125: 886-889.

104 Clark GM, Mathieu MC, Owens MA, Dressler LG, Fudey L, Formey DC, Osborne CK, Gilchvist $\mathrm{KW}$, Mansour EG, Abeloff MD, McGuire WL. Prognostic significance of S-phase fraction in good risk, node-negative breast cancer patients.

J Clin Oncol 1992; 10:428-432.

105 McDivitt RW, Stone KR, Craig B, Palmer J, Meyer IS, Bauer WC. A proposed classification of breast cancer based on kinetic information. Cancer 1986; 57: 269-276.

106 Fallenius AG, Auer GU, Carstensen JM. Prognostic significance of DNA measurements in 409 consecutive breast cancer patients. Cancer $1988 ; 62: 331$-334.

107 Amerløv C, Edmin SO, Roos G, Angström T, Bjernsing L, Angquist K-A, Larsson L-G, Jonsson $H$. Prognostic factors in locally advanced breast cancer $\left(T_{3}, T_{4}\right)$ with special reference to tumour cell DNA content. Acta Oncol 1988; 27: 221-226.

108 Christow K, Milev A, Todorow V. DNA aneuploidy and cell proliferation in breast tumours. Cancer 1989; 64: 673-679.

109 Feichter GE, Mueller A, Kauffman M, Haag D, Born IA, Abel U, Klingma K, Kubli F, Goertter $K$. Correlation of DNA flow cytometric results and other prognostic factors in primary breast cancer. Int $J$ Cancer $1988 ; 41: 823-828$.

110 Edward Lewis W. Prognostic significance of flow cytometric DNA analysis in nodenegative breast cancer patients. Cancer $1990 ; 65: 2315-2320$. 
111 Dowle $C S$, Owainati $A$, Robins $A$, Burns $\mathbb{K}$, Ells 10 , Elston $C W$ and Blamey $\mathbb{R} W$. Prognostic significance of the DNA content of human breast cancer.

Br J Surg 1987; 74: 133-136.

112 Lewis WE. Prognostic significance of flow cytometric DNA analysis in node-negative breast cancer patients. Cancer 1990; 65: 2315-2320.

113. Visscher DW, Zarbo RJ, Jacobsen G, Kambouris A. Talpos G, Later W and Crissman JD. Multipartametric doxyribonucleic acid and cell cycle analysis of breast carcinomas by flow cytometry: clinicopathologic correlations. Lab Invest 1990; 62: 370-378.

114 Uyterlinde AM, Schipper NW, Baak JPA. Comparison of extent of disease and morphometric flow cytometry prognostic factors in invasive ductal breast cancer.

J Clin Pathol 1987; 40: 1432-1436.

115 Koike H. The impact of DNA ploidy and proliferation index on survival of breast cancer patients. Mie Med I 1988; 38: 111-124.

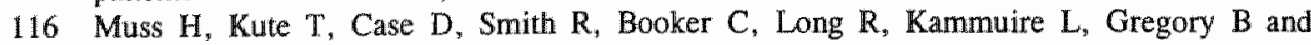
Brockschmidt. The relation of flow cytometry to clinical and biologic characteristics in wornen with node-negative primary breast cancer. Cancer 1989; 64: 1894-1900.

117 Kallioniemi $O P$, Blanco $G$, Alavaikko $M$, Hietanen $T$, Matilla J, Lauslahti $H$, Lehtinen $M$ and Koivula $\mathrm{T}$. Improving the prognostic value of DNA flow cytometry in breast cancer by combining DNA index and S-phase fraction. A proposed classification of DNA histograms in breast cancer. Cancer 1988; 62:2183-2190.

118 Jakobsen A, Skovgaard Poulsen HS, Lindegaard Madsen EL, Elleback Petersen SE and Lindegaard Hanssen HS. Ploidy level of human breast carcinoma.

Acta Radiol Oncol 1984; 23: 103-107.

119 Kute TE, Muss HB, Hopkins M, Marshall R, Case D and Kammire L. Relationship of flow cytometric results and steroid-receptors in human breast cancer.

Breast Cancer Research and Treatment 1985; 6: 113-121.

120 Stuart-Harris R, Hedley DW, Taylor IW, Levene AL and Smith IE. Tumour ploidy, response and survival in patients receiving endocrine therapy for advanced breast cancer. Br J Cancer 1985; $51: 573-576$.

121 Hedley DW, Rugg CA, Ng ABP and Taylor IW. Influence of cellular DNA content on disease free survival of stage II breast cancer patients. Cancer Res 1984; 44: 395-398.

122. Helin HJ, Markku HJ, Kallioniemi OP, Isola JJ. Immunohistochemical determination of oestrogen and progesterone-receptors in human breast carcinoma.

Cancer $1989 ; 63: 1761-1767$.

123 Auer GU, Ericksson E, Azavedo E, Caspersson $T$ and Wallgren A. Prognostic significance of nuclear DNA content in mammary adenocarcinomas in humans.

Cancer Res 1984; 44: 394-396.

124 Baildam AD, Zaloudik $\mathbf{J}$, Howell A, Barnes DM, Tumbull L, Swindell R, Moore M and Sellwood RA. DNA analysis by flow cytometry, response to endocrine treatment and prognosis in advanced carcinoma of the breast. Br J Cancer 1987; $55: 553-559$.

125 Kallioniemi $O P$, Hietanen $T$, Mattila $J$, Lehtinen $M$, Lanslahti $K$, Koivula $T$. Aneuploid DNA content and high $S$-phase fraction (SPF) of tumour celis are related to poor prognosis in primary breast cancer. Eur J Clin Oncoll 1987; 23: 277-282.

126 Keyhani-Rofagha S, O'Toole RV, Farrar WB, Sickle-Santanello B, De Cenzo J and Young D. Is DNA ploidy an independent prognostic factor in infiltrative node-negative breast adenocarcinoma. Cancer 1990; 65: 1577-1582.

127 Toikkanen $S$, Joensuu $H$ and Klemi $P$. Nuclear DNA content as a prognostic factor in $T_{1-2}$ $\mathrm{N}_{0}$ breast cancer. Am I Clin Pathol 1990; 93; $471-479$.

128 Braglan RC. Flow cytometry. Arch Pathol Lab Med 1983; 107: 1-6. 
129 Sigurdsson $\mathrm{H}$, Baldetorp B, Borg A, Dalberg $M$, Fernö $M$, Killander $D$ and Olsson $H$. Indicators of prognosis in node-negative breast cancer.

N Engl J Med 1990; 322: 1045-1053.

130 Hitchcock A, Ellis IO, Robertson JFR, Gilmour A, Bell J, Elston CW and Blamey RW. An observation of DNA ploidy , histological grade and immunoreactivity for tumour related antigens in primary and metastatic breast carcinoma. J Pathol 1989; 159: 129-134.

131 Prey MU, Meyer JS, Stone KR and MCDivitt RW. Heterogeneity of breast carcinomas determined by flow cytometric analysis. I Surg Oncol 1985:29:35-39.

132 Beerman 4 , Smith VTHBM, Klein PhM, Bonsing BA, Hermans $J$ and Cornelisse CJ. Flow cytometric analysis of DNA stemline heterogeneity in primary and metastatic breast cancer. Cytometry 1991; 12: 147 154.

133 Feichter $\mathrm{GE}$, Kaufmann M, Muller A, Haag D, Eckhardi $\mathrm{R}$ and Goerttler $\mathrm{K}$. DNA index and cell cycle analysis of primary breast cancer and synchronous axillary node metastases. Breast Cancer Res Treat 1989; 13: 17-22.

134 Olszewski W, Darzynkiewicz Z, Rosen PP, Claps ML and Melamed MR. Flow cytometry of breast cancer: III possible altered kinetics in axillary lymph node metastases. Anall Quant Cytol 1982; 4: 275-279.

135 Raber MN, Barlogie B, Latreille J, Bedrossian C, Fritsche $\mathrm{H}$ and Blumenschein $\mathrm{G}$. Ploidy, proliferative activity and oestrogen-receptor content in human breast cancer. Cytometry $1982 ; 3: 36-41$.

136 Remvikos $\mathrm{Y}$, Magdelenat $\mathrm{H}$ and Zajdela A. DNA flow cytometry applied to fine needle sampling of human breast cancer. Cancer 1988; 61: 1629-1634. 


\section{ADJUVANT CHEMO-HORMONAL THERAPY WITH CYCLOPHOSPHAMIDE, DOXORUBICIN AND 5-FLUOROURACIL (CAF) WITH OR WITHOUT MEDROXYPROGESTERONE ACETATE FOR NODE-POSITIVE BREAST CANCER PATIENTS}

PSGJ Hupperets, JAJM Wils, L Volovics, LJ Schouten, MMF Fickers, HNLM Bron, HC Schouten, JJ Jager, JMA de Jong, HFP Hillen, GH Blijham for the Comprehensive Cancer Center Limburg Breast Cancer Study Group 


\section{ADJUVANT CHEMO-HORMONAL THERAPY WITH CYCLOPHOSPHAMIDE, DOXORUBICIN AND 5-FLUOROURACIL (CAF) WITH OR WITHOUT MEDROXYPROGESTERONE ACETATE FOR NODE-POSITIVE BREAST CANCER PATIENTS}

\section{ABSTRACT}

\section{Background}

The Comprehensive Cancer Center triall 82-01 is a prospective randomized study to investigate the value of the addition of high dose medroxyprogesterone acetate (MPA) to chemotherapy in patients with node-positive operable breast cancer. MPA may be of advantage in this setting because of its activity in oestrogen-receptor (ER)-positive as well as ER-negative tumours and since it may protect against chemotherapy-induced myelosuppression and thus enable maintenance of the appropriate chemotherapeutic scheduling.

\section{Patients and methods}

Four hundred eight evaluable patients with node-positive $(\mathrm{N}+)$ operable breast cancer $\left(\mathrm{T}_{1-3,3}, \mathrm{~N}_{1}\right)$ were entered in a multicenter randomized trial. Two hundred nine patients were randomized in the MPA- arm and 199 in the MPA + arm. CAF chemotherapy was given as a short i.v. bolus infusion: cyclophosphamide $500 \mathrm{mg} / \mathrm{m}^{2}$ i.v. day 1 , doxorubicin 40 $\mathrm{mg} / \mathrm{m}^{2}$ i.v. day 1 and 5 -fluorouracil $500 \mathrm{mg} / \mathrm{m}^{2}$ i.v. day 1 , q 4 wks $\times 6$. MPA was given intramuscularly (i.m.) $500 \mathrm{mg} \mathrm{q} \mathrm{d} \mathrm{x} 28$ days, followed by $500 \mathrm{mg}$ i.m. twice weekly during 5 months.

\section{Results}

The main side effects of MPA were weight gain with a mean of $5.5 \mathrm{~kg}$ as opposed to 1.8 $\mathrm{kg}$ in the control group $(\mathrm{p}=0.01)$ and vaginal bleeding in 30/199 in the MPA+ group and 0 in the MPA- group. MPA ameliorated vomiting grade III, IV (45\% vs $28 \%$, $\mathrm{p}<0.001$ ), nausea grade III, IV (50\% vs $34 \%, \mathrm{p}<0.001$ ) and leucocyte nadir grade III, IV (20\% vs $11 \%, \mathrm{p}=0.003$ ). Disease-free survival (DFS) after 5 years was $59 \%$ in the MPA + and $49 \%$ in the MPA- group $(p=0.12)$. Patients $\geq 60$ years benefitted most from MPA treatment, in particular if freedom from distant metastases was taken as the endpoint $(p=0.02)$. Overall survival (OS) was not significantly different between the two treatment groups $(p=0.18)$, but within subgroups analyzed there was an advantage for MPA + in patients $\geq 55$ years $(p=0.002)$ and in $\mathrm{pT}_{\|}$patients $(\mathrm{p}=0.045)$.

\section{Conclusions}

High dose MPA ameliorates CAF side effects and reduces the risk of metastatic disease, especially in elderly breast cancer patients. 


\section{INTRODUCTION}

In the early 1980 s the results of adjuvant chemotherapy studies from the NSABP ${ }^{1}$ and the Milan Group ${ }^{2.3}$ began to show a statistically significant benefit in terms of treatment failure for women with node-positive breast cancer treated who received chemotherapy as compared to those in the observation group. With the maturation of these studies and the results of subsequently initiated trials it has now become possible to conduct a metaanalysis that has clearly confirmed this benefit for premenopausal and also, although to a lesser extent, for postmenopausal women in terms of both disease-free (DFS) and overall survival (OS). In this time period, data from studies with adjuvant hormonal treatment have only slowly been accumulated. It appears now that adjuvant treatment with tamoxifen improves DFS in node-positive breast cancer patients, but overall survival advantage is more difficult to demonstrate, and in the meta-analysis OS reaches significance only in patients over 50 years of age.

At present, the least understood situation in adjuvant treatment of breast cancer is the use of combinations of cytostatic and hormonal adjuvant therapies. In metastatic breast cancer chemo-hormonal therapy is distinctly superior to chemotherapy alone ${ }^{5.6}$. In the 1980 s a number of trials were initiated that sought to investigate the effectiveness of the addition of 1 year of tamoxifen to a CMF-type chemotherapy ${ }^{7-15}$. In general, these studies, although sometimes suggesting a superiority of the combination in subgroups of patients for disease-free interval ${ }^{16,17}$ have yielded negative results. Discrepancies in therapeutic findings are still unexplained, but could be related to interactions between chemotherapy and hormonal drugs ${ }^{18,19}$ or to the short duration of hormonal therapy ${ }^{11}$.

In 1982 we started to address the question of the efficacy of various chemo-hormonal adjuvant therapy regimens because their results were better than those of cyclophosphamide, methotrexate and 5-fluorouracil (CMF)-based combinations ${ }^{20}$ in metastatic breast cancer, and because in non-randomized studies, the number of positive lymph nodes and the menopausal status had been observed to have less influence on the efficacy of such adjuvant therapy ${ }^{21}$. We chose a doxorubicin-containing cytotoxic regimen. Medroxyprogesterone acetate (MPA), that had not been adequately tested in an adjuvant setting, was used as hormonal treatment because of its considerable activity in oestrogen-receptor ER-positive and possible activity in ER-negative tumours ${ }^{6.22}$. Because of the bone marrow protective activity of MPA against chemotherapy-induced toxicity, this agent could also make it possible for the appropriate chemotherapeutic dose-intensity to be maintained ${ }^{23}$. Here we report the results of this study after a median follow-up of 42 months.

\section{PATIENTS AND METHODS}

\section{Patient Eligibility}

Premenopausal, and postmenopausal women younger than 71 years with histologicallyproven infiltrative breast cancer treated with a modified radical mastectomy or lumpectomy with postoperative breast irradiation, having one or more 
histopathologically-involved ipsilateral axillary lymph nodes, were considered for entry in the protocol. Lumpectomy was performed in patients with a primary tumour of $3 \mathrm{~cm}$ or smaller. Postlumpectomy breast irradiation consisted of $50.00 \mathrm{~Gy}$ to the total breast with a boost of $14.00 \mathrm{~Gy}$ to the operated region. Patients with carcinoma in situ, billateral breast carcinoma, inflammatory breast cancer or $\mathrm{T}_{4}$ primary tumour, nodal fixation or supraclavicular nodal involvement and/or evidence of disseminated disease at presentation were ineligible for the study. Other eligibility criteria included a normal bone scan, no previous or concomitant malignancy (except curatively treated (non melanoma) skin cancer or cervix carcinoma in situ), and no pregnancy or lactation at the time of diagnosis of breast carcinoma. Exclusion criteria for entry were haemoglobin level $<6.5 \mathrm{mmol} / \mathrm{l}$, leucocyte count $<3.10^{9} / \mathrm{l}$ or platelet count $<100.10^{9} / \mathrm{l}$ and medical illnesses precluding the treatment options (e.g., recent myocardial infarction, a history of thromboembolism and congestive heart failure). Informed consent was required according to the institutional guidelines. The protocol had been approved by the institutional committees for medical ethics. The patients were staged according to the TNM system adapted by both the Union Internationale Contre le Cancer and the American Joint Commission on Cancer Staging ${ }^{24}$.

\section{Randomization}

Randomized treatment assignments took place by telephone call to the office of the Comprehensive Cancer Center Limburg. Registration and randomization of patients occurred preoperatively but only patients with postoperative positive nodes were subsequently treated according to the assigned treatment.

\section{Study design}

All patients were treated with adjuvant chemotherapy. Randomization determined whether or not patients also received MPA. The adjuvant chemotherapy consisted of six 28-day cycles beginning within 4 weeks after primary surgery. In cases of postoperative breast irradiation, both modalities were combined with chemotherapy starting just prior to the radiotherapy. Each cycle of the CAF regimen consisted of cyclophosphamide $500 \mathrm{mg} / \mathrm{m}^{2}$ intravenously (i.v.) on day 1 , doxorubicin $40 \mathrm{mg} / \mathrm{m}^{2}$ i.v. on day 1 and 5-fluorouracil $500 \mathrm{mg} / \mathrm{m}^{2}$ i.v. on day 1. MPA (Farlutal ${ }^{\mathbb{R}}$ ) was administered daily in a dose of $500 \mathrm{mg}$ intramuscularly (i.m.) days 1 through 28 and twice a week thereafter for a total period of 6 months (figure 1 ).

\section{Drug dosage modification}

Treatment delays of up to 2 weeks were allowed for each cycle to allow for recovery from haematologic toxicity. If on day 28 leucocyte count was $<3.10^{9} / \mathrm{l}$ and/or platelets $\leq 100.10^{9} / 1$ the CAF chemotherapy course was postponed for 1 week. One hundred percent of the CAF regimen was given if leucocytes were $>3.10^{9} / 1$ and platelets $>100.10^{9} / 1$. CAF doses were reduced to $50 \%$ if leucocytes were between $2.10^{\%} / 1$ and $3.10^{\circ} / 1$ and/or platelets between $50.10^{9} / 1$ and $100.10^{\circ} / 1$ after a one-week postponement. CAF chemotherapy was discontinued if the leucocyte count after a one-week postponement was $<2.10^{9} / 1$ and/or platelets $<50.10^{9} / 1$; in such cases the patients went off study. MPA $500 \mathrm{mg}$ intramuscularly daily could be replaced by oral intake of $1.000 \mathrm{mg}$ daily in instances of local pain or local infections. MPA treatment was stopped 
when it caused unacceptable toxicity for the patient (e.g., unacceptable weight gain. vaginal bleeding) or thrombo-embolic complications. Toxicity was assessed by the WHO criteria $^{25}$.

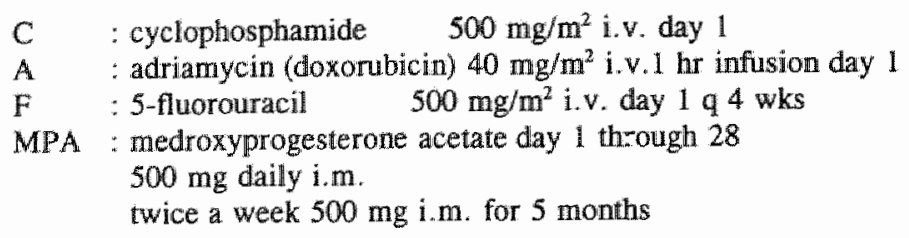

WBC $<3.10^{\circ} / 1$ and/or platelets $\leq 100.10^{9} / 1: \mathbb{1}$ week postponement

$\begin{array}{lcll}\text { After one week postponement } & & \\ \text { WBC/PIt } & >100 & 50-100 & <50 \\ >3 & 100 \% & 50 \% & \text { off prot. } \\ 2-3 & 50 \% & 50 \% & \text { off prot. } \\ <2 & \text { off prot. } & \text { off prot. } & \text { off prot. }\end{array}$

Figure 1 CAF-MPA regimen.

\section{Patient evaluation}

Follow-up included a history and physical examination every 3 months during the first 2 years, every 4 months in the third year, every 6 months in the fourth and fifth years and every 12 months thereafter. Blood counts, alkaline phosphatase, gamma-glutamic transferase, lactodehydrogenase, calcium, and erythrocyte sedimentation rate were determined at the same intervals. Chest radiographs and mammography were performed every year.

\section{Patient accrual}

Accrual was from May, 1982 through July, 1987. Four hundred eight patients fulfilled the entry criteria and were treated according to the preoperatively assigned treatment arm. Two hundred nine patients have received the non-hormonal treatment arm (MPA-) and 199 patients the MPA + arm. The small imbalance between the two treatment groups is due to double randomizations, pre- and postoperatively, of 7 patients. Nineteen patients were randomized for MPA + but never received hormonal treatment. These 19 patients are included in the MPA+ arm. The median follow-up of this report is 42 months.

\section{Statistical methods}

The influence of the addition of hormonal therapy on the endpoints of interest: overall survival (OS), disease-free survival (DFS), survival to loco-regional relapse and survival to distant metastases, was primarily analyzed using Kaplan-Meier survival curve estimates and the logrank test ${ }^{35}$.

However, as there are some slight imbalances with respect to the distribution of patient characteristics between the MPA+ and MPA- treatment arms, the influence of MPA on 
survival was additionally analyzed using Cox's proportional hazards model to control for possible confounding. Essentially the same results were obtained as with the KaplanMeier/log rank test analysis. Risk ratios and $95 \%$ confidence intervals were estimated using the proportional hazards model to fit only the MPA effect. All Kaplan-Meier curves are presented with 95\% simultaneous confidence bands following Hall \& Wellner ${ }^{26}$. Confidence bands for two curves, CAF vs CAF + MPA, are adjusted with the Bonferroni inequality to give an overall simultaneous $95 \%$ coverage probability. The Cox's proportional hazards model was also used to adjust for confounding while looking for subgroups of patients with good response to CAF+MPA therapy. This subgroup exploration was done through fitting all interaction terms of all relevant variables with MPA using backward elimination with a p-value of 0.10 . The subgroups showing a large difference in survival curves are presented. We present here Kaplan-Meier curves estimated for the actual subgroups and not adjusted curves based on the proportional hazards model. Statistics were also calculated for the actual subgroups. We would like to point out that this subgroup search was only made as an inquiry as to possible topics for further research. The assumptions of the proportional hazards regression model are carefully checked using graphical methods and Schoenfeld tests and this results in transforming some prognostic variables to improve fit. Undue influence of individual patients on results was also checked using influence and residual plots ${ }^{27}$.

\section{RESULTS}

The two treatment regimens are generally well balanced with respect to the analyzed patient characteristics (table I). Checks, controlling for these slight imbalances in treatment comparisons, do not indicate confounding.

The OS curves and DFS curves for all 408 patients at a median follow-up of 42 months are shown in figures 2 and 3 respectively. The DFS and OS were $73 \%$ and $80 \%$, respectively, at 42 months. 
Table I Patient Characteristics

\begin{tabular}{|c|c|c|c|c|}
\hline & \multicolumn{4}{|c|}{ Treatment (CAF) } \\
\hline & \multicolumn{2}{|c|}{ MPA $(209)$} & \multicolumn{2}{|c|}{ MPA $+(199)$} \\
\hline & No & $(\%)$ & No & $(\%)$ \\
\hline \multicolumn{5}{|l|}{ Characteristic: } \\
\hline age premenopausal & 113 & $(54 \%)$ & 123 & $(62 \%)$ \\
\hline postmenopausal & 96 & $(46 \%)$ & 76 & $(38 \%)$ \\
\hline Weight $(\mathrm{kg} \geq 74 \mathrm{~kg})$ & 44 & $(21 \%)$ & 50 & $(25 \%)$ \\
\hline $\mathbb{E R}$ pos. ( $\geq 10 \mathrm{fmol} / \mathrm{mg}$ prot.) & 148 & $(71 \%)$ & $\mathbb{3 1}$ & $(66 \%)$ \\
\hline \multicolumn{5}{|l|}{ Tumour stage (AJCC classification) } \\
\hline 1 & 31 & $(15 \%)$ & 26 & $(13 \%)$ \\
\hline $11 \mathrm{~A}+\mathrm{B}$ & 144 & $(69 \%)$ & 147 & $(74 \%)$ \\
\hline IIIA & 33 & $(16 \%)$ & 28 & $(14 \%)$ \\
\hline $\mathrm{T}_{1}(\mathrm{TNM}$ class $)$ & 54 & $(26 \%)$ & 64 & $(32 \%)$ \\
\hline $\mathrm{T}_{2}$ & 136 & $(65 \%)$ & 115 & $(58 \%)$ \\
\hline $\mathrm{T}_{3}$ & 19 & $(9 \%)$ & 20 & $(10 \%)$ \\
\hline \multicolumn{5}{|l|}{ Number of axillary nodes } \\
\hline $1-4$ & 134 & $(65 \%)$ & 135 & $(68 \%)$ \\
\hline $5-9$ & 54 & $(26 \%)$ & 46 & $(23 \%)$ \\
\hline$\geq 10$ & 19 & $(9 \%)$ & 18 & $(9 \%)$ \\
\hline$\%$ died from malignancy & 56 & $(27 \%)$ & 48 & $(24 \%)$ \\
\hline & \multicolumn{4}{|c|}{$\%$ relapsed } \\
\hline locoregional* & 23 & $(11 \%)$ & 22 & $(12 \%)$ \\
\hline metastatic & 65 & $(31 \%)$ & 44 & $(22 \%)$ \\
\hline locoregional + metastatic & 12 & $(6 \%)$ & 10 & $(5 \%)$ \\
\hline $\begin{array}{l}\text { chemotherapy dose reduction } \\
\qquad(0 \%-10 \%)\end{array}$ & 25 & $(12 \%)$ & 14 & $(7 \%)$ \\
\hline
\end{tabular}

* chest wall relapse after mastectomy or mammary relapse after lumpectomy and/or ipsilateral axillary lymph node metastases or ipsilateral supraclavicullar lymph node metastases 
overalll survival

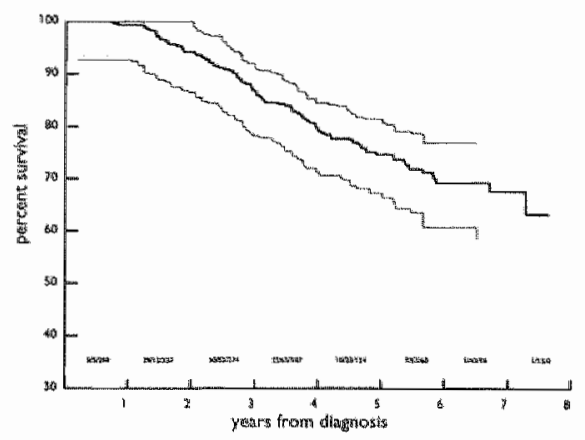

Figure 2 Overall survival (OS) curve for all node-positive patients $(n=408)$.

Dotted lines represent. $95 \%$ simultaneous confidence bounds.

$\mathrm{a} / \mathrm{b} / \mathrm{c}$ : a. represents the number of patients dying from breast cancer in the one year interval.

b. represents the number of patients without further follow-up or dying from other causes.

c. represents the number of patients alive and still at risk of dying at the end of the one year interval.

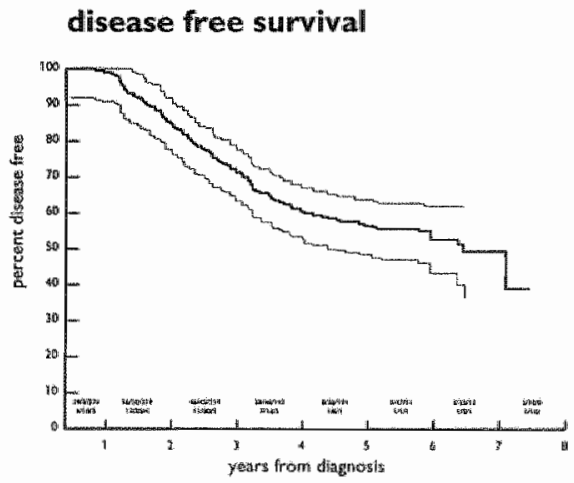

Figure 3 Disease-free survival (DFS) curve for all node-positive patients $(n=408)$.

Dotted lines represent $95 \%$ simultaneous confidence bounds.

$\mathrm{a} / \mathrm{b} / \mathrm{c} / \mathrm{a}$. represents the number of patients with distant metastases or loco-regional recurrence.

b. represents the number of patients without further follow-up or dying from other causes.

c. represents the number of patients still alive and at risk of recurrence at the end of the one year interval.

$\mathrm{d} / \mathrm{e} / \mathrm{f} / \mathrm{s}$ d. represents the number of patients with locio-regional recurrence..

e. represents the number of patients with distant metastases.

f. represents $d+e$

$d+e+f=a$. 


\section{DFS comparisons between the two regimens}

A difference in DFS between the two regimens as far as all recurrences are concerned has been found, $59 \%$ vs $49 \%$ at 5 years in favour of the MPA+ arm, but the difference is currently not statistically significant $(p=0.12)$ (figure 4). An estimate for the relative (MPA + versus MPA-) rate of occurrence of distant metastases or loco-regional relapses is 0.79 . A $95 \%$ confidence interval for the true rate is $(0.59,1.07)$. However, if the comparison is carried out with the occurrence of all relapses for the subgroup of patients aged $\geq 60$ and $\leq 70$ years the two curves differ almost significantly, $62 \%$ vs $41 \%$ at 5 years in favour of the MPA+ treatment arm (figure 5) $(p=0.06)$. An estimate for the relative (MPA+ versus MPA-) rate of occurrence of all relapses is 0.57 . A 95\% confidence for the true value is $(0.32,1.03)$. This difference is even more marked for the occurrence of distant metastases as endpoint in patients aged $\geq 60$ and $\leq 70$ years $(p=0.02)$. The curves diverge from the first year of follow-up and a slightly more than $10 \%$ difference can be seen after a follow-up period of 5 years.

No significant differences in disease-free survival can be found in this study within subgroups according to tumour size, steroid-receptor value (the relative rate of recurrence is 1.02 for ER and 0.83 for $\mathrm{PgR}$ ) or number of positive nodes.

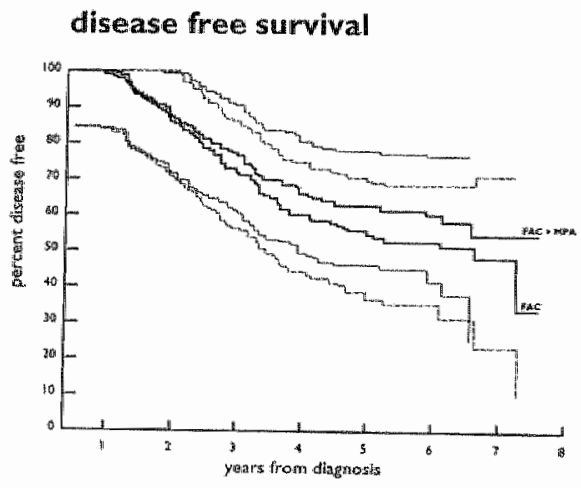

Figure 4 Disease free survival (DFS) curves for both treatment arms for all types of relapses (locoregional, distant metastases and both types simultaneously) $(\mathrm{p}=0.12)$.

Dotted lines represent $95 \%$ simultaneous confidence bounds. 


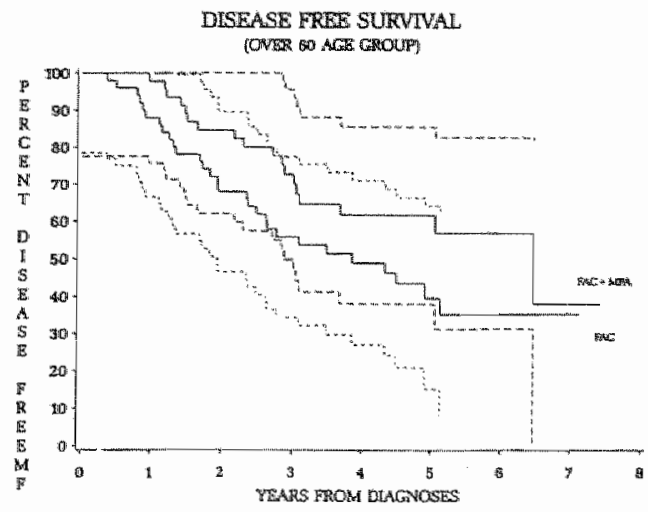

Figure 5 Disease free survival (DFS) curves for both treatment arms for all types of relapses in patients $\geq 60$ and $\leq 70$ years. Difference in favour of the FAC + MPA treatment arm $(\mathrm{p}=0.06)$.

Dotted lines represent $95 \%$ simultaneous confidence bounds.

Overall survival (os) comparisons between the two regimens

There is currently no significant $O S$ benefit for either of the two regimens (figure 6). An estimate of the relative rates (MPA+ versus MPA-) of cancer related death is 0.88 . A $95 \%$ confidence interval for the true rate is $(0.60,1.30)$. There are no differences within subgroups of stage $T_{2}$ and $T_{3}$, ER or $P g R$ status or the number of positive nodes. However, within the subgroups analyzed there is a survival advantage for CAF + MPA over CAF in elderly patients, statistically most significant in the group of patients $\geq 55$ and $\leq 70$ years of age $(p=0.002)$ and in pathologically staged $T_{1}$ patients $(p=0.045)$.

\section{overall survival}

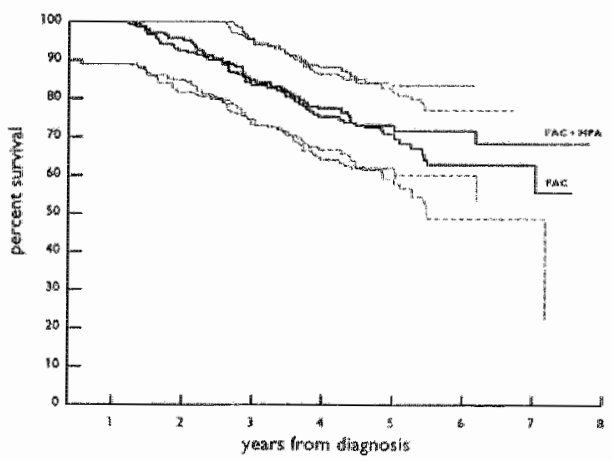

Figure 6 Overall survival (OS) curves for both treatment arms. Only patients who died because of progressive breast cancer were analyzed. No difference between the two survival curves.

Dotted lines represent $95 \%$ simultaneous confidence bounds. 


\section{Toxicity of the treatment}

Six cycles of chemotherapy were administered to all patients. In the MPA + treatment group 18 (9\%) patients discontinued MPA treatment during the adjuvani course, 2 patients in the first month, 12 in the third, 3 in the fourth and 1 in the fifth month. MPA-related toxicity has been assessed by comparing CAF + MPA with CAF. The major side effects encountered are shown in table II. The addition of MPA is associated with significantly less nausea $(p<0.001)$, vomiting $(p<0.001)$ and grade III and IV nadir leucocytopenia $(p=0,003)$. Four weeks after initiation of chemotherapy no significant differences in leucocyte count could be found. No differences were observed in platelet count and granulocytopenia grade III and IV toxicity. In the CAF + MPA treament group a mean weight gain is recorded of $5.5 \mathrm{~kg}$ whereas weight gain in the CAF treatment group did not exceed $1.8 \mathrm{~kg}$ (table 2). The CAF chemotherapy was well tolerated with $97 \%$ of the planned dose given for patients without MPA, and $98 \%$ to those with MPA. Only 5\%, 10 patients, (without MPA) and 2\%, 4 patients (with MPA) discontinued CAF chemotherapy prematurely.

Table II Major Side Effects Occurring During Treatment with each Regimen (\%)

\begin{tabular}{|c|c|c|c|c|c|}
\hline \multirow{2}{*}{$\begin{array}{l}\text { Side Effect } \\
\text { Infiltrate in injected muscle }\end{array}$} & \multicolumn{2}{|l|}{$\begin{array}{l}\text { CAF } \\
209 \\
\text { No }\end{array}$} & \multicolumn{2}{|c|}{$\begin{array}{l}\text { CAF + MPA } \\
199 \\
\text { No }\end{array}$} & \multirow[t]{2}{*}{$\mathrm{p}$-value } \\
\hline & & & 11 & $(6 \%)$ & \\
\hline Vomiting (gr.III, IV) & 97 & $(46 \%)$ & 57 & $(28 \%)$ & $<0,001$ \\
\hline Nausea (gr.III, IV) & 106 & $(51 \%)$ & 68 & $(34 \%)$ & $<0,001$ \\
\hline Lencocyte nadir (III, IV) & 42 & $(20 \%)$ & 22 & $(11 \%)$ & $=0,003$ \\
\hline Leucocyte count at 4 wks & & & & & \\
\hline after treatment (II, III) & 23 & $(11 \%)$ & 16 & $(8 \%)$ & N.S. \\
\hline Granulocytes nadir (III, IV) & 38 & $(18 \%)$ & 40 & $(20 \%)$ & N.S. \\
\hline Granulocytes at 4 wks (I, III) & 25 & $(12 \%)$ & 18 & $(9 \%)$ & N.S. \\
\hline Platelets nadir $\left(I_{*} I I\right)$ & 2 & $(11 \%)$ & 2 & $(1 \%)$ & \\
\hline Platelets at 4 wks (I) & 2 & $(1 \%)$ & 2 & $(1 \%)$ & \\
\hline Vaginal bleeding & 0 & $(0 \%)$ & 30 & $(15 \%)$ & \\
\hline Weight gain (kg) & 1.8 & & 5.5 & & $=0.01$ \\
\hline
\end{tabular}

\section{DISCUSSION}

Although no survival or disease-free survival difference for all treated patients is observed, the current trial has demonstrated a therapeutic benefit of MPA added to CAF in terms of OS in elderly ( $\geq 55$ years) patients. Only one other trial has studied a similar question $^{28}$. In that sudy, MPA added efficacy to CMF treatment; this effect is restricted to patients over 50 years of age. The Early Breast Cancer Trialists' Collaborative Group has reported on the combination of tamoxifen with chemotherapy, mostly of the CMF yype ${ }^{4}$. Whereas results of earlier studies of this type using 1 year of tamoxifen treatment were generally negative ${ }^{7.15}$, the meta-analysis of trials with an average of 2 years of treatment shows a reduction in odds of recurrence of $7 \%$ for patients under and $28 \%$ for patients over 50 years of age. Therefore, as with MPA combined with CAF, tamoxifen 
appears to add efficacy to the CMF type of adjuvant chemotherapy in elderly patients with breast cancer. Direct comparisons between the efficacy of MPA and tamoxifen in adjuvant treatment are not available but might be worth performing in view of the increase in response rates with MPA over those with tamoxifen in patients with metastatic disease ${ }^{22}$; this, however, has not been uniformly found ${ }^{29}$ and may be doserelated ${ }^{30}$.

MPA does not appear to significantly affect the occurrence of locoregional relapse. This is also reflected in the finding that the MPA effect is positively associated with the presence of small primary tumours $\left(\mathrm{T}_{1} ; \mathrm{p}=0.05\right)$ for survival in this group. The locoregional failure rate of $11 \%-12 \%$ in our study after a median follow-up of 42 months is comparable to that reported by the Italian Breast Cancer Adjuvant Chemo-Hormone Therapy Cooperative Group, Grocta ${ }^{13}$ and the North Central Cancer Treatment Group in their trial of combined chemo-hormonal therapy ${ }^{9}$. In both these studies the addition of tamoxifen for 5 years (Grocta) or 1 (NCCTG) year did not improve locoregional control (10\% relapse rate for Grocta and $13 \%$ for NCCTG) over that of chemotherapy alone. We conclude that high-dose MPA offers no advantage over tamoxifen with respect to locoregional control in patients treated with adjuvant chemotherapy.

The meta-analysis has provided evidence that the adjuvant effect of tamoxifen is dependent (though not completely) on the presence of oestrogen-receptors ${ }^{4}$. This may in part explain why in our study elderly patients responded to MPA adjuvant treatment, since this group tend to have higher ER-levels. Oestrogen-receptor content, bowever, did not predict for MPA efficacy. In the current study MPA was given over a period of time which, in light of current knowledge, was probably too short for provision by an endocrime mechanism of a meaningful adjuvant effect.

P-glycoprotein mediated multidrug resistance (MDR) may be important in breast cancer patients, particularly during treatment with anthracyclines ${ }^{31}$. There is evidence that tamoxifen can reverse $\mathrm{MDR}^{32}$. Until now there have been no clinical studies of the influence on MDR by high doses of MPA, but in vitro studies suggest that progesterone interacts with $\mathbb{P}$-glycoprotein and is capable of reversing drug resistance in MDR-positive cells $^{33}$. Results of the current study using short-term high-dose MPA concurrently with an anthracycline-containing adjuvant chemotherapy may be an expression of this interaction at the clinical level.

The addition of MPA to CAF is associated with a higher incidence of cushingoid changes, weight gain and local infections due to the intramuscular application of MPA. These side effects caused $9 \%$ of treated patients to discontinue treatment. A beneficial effect of MPA in this trial is bone marrow protection, in particular an amelioration of the white blood cell nadir. However, this did not lead to a higher dose-intensity and therefore is not the explanation for the differences in efficacy. Nausea and vomiting were partly prevented by the addition of MPA. This is probably due to the corticosteroid activity of the drug ${ }^{34}$.

In conclusion, this trial suggests a beneficial effect of MPA in combination with chemotherapy on the occurrence of distant metastases in stage II breast cancer patients. 
Currently the trial does not show an overall survival advantage but the present rend in favour of the MPA plus CAF treatment group may well become a significant difference after a longer follow-up period. As high-dose MPA ameliorates CAF side effects and improves the efficacy when combined with CAF chemotherapy in the elderly breast cancer patients, the combination of MPA plus chemotherapy deserves further investigation in elderly breast cancer patients, irrespective of steroid-receptor status. 


\section{REFERENCES}

1 Fisher B. The contribution of recent NSABP clinical trials of primary breast cancer therapy to an understanding of tumour biology: an overview of findings.

Cancer $1980 ; 46: 1009-1025$.

2 Bonadonna G. Are surgical adjuwant trials altering the course of breast cancer. Simin Oncol $1978 ; 5: 450-465$.

3 Bonadonna G, Valagussa P. Dose-response effect of adjuvant chemotherapy in breast cancer. New Engl J Med 1981; 304: 10-16.

4 Anonymous. Systemic treatment of early breast cancer by hormonal, cytotoxic or immune therapy. Early breast cancer trialists' collaborative group. The Lancet 1992; 339: 71-84.

5 Tormey DC, Gelman $\mathbb{R}$, Band PR et al. Comparison of induction chemotherapies for metastatic breast cancer: an Eastern Cooperative Oncology Group Trial.

Cancer 1982; 50: 1235-1244.

6 Gundersen S, Kvinnsland S, Klepp $O$ et al. Chemotherapy with or without high-dose medroxyprogesterone acetate in oestrogen-receptor-negative advanced breast cancer.

Eur J Cancer 1992; $28: 390-394$.

7 Hubay CA, Gordon NH, Crowe JP et al. Antiestrogen-cytotoxic chemotherapy and bacillus Calmette-Guerin vaccination in stage II breast cancer: seventy-two months follow-up. Surgery $1984 ; 96: 61-72$.

8 Mauriac L, Durand $M$, Chaurvergne J, Bichon $F$, Avril A, Mage P, Dilhuydy M, le Trent A, Wafflart $\mathbf{J}$, Marée $\mathrm{D}$ and Lagarde $\mathrm{C}$. Adjuvant trial for stage II receptor-positive breast cancer: CMF us CMF plus tamoxifen in a single centre.

Breast Cancer Research and Treatment 1988:11:179-186.

9 Ingle IN, Eversson LK, Wieland HS, Martin JK, Votava HJ, Wolld LE, Krook JE, Cullinan SA, Paulsen JK, Twito DI, Ahmann DL, Foley JF, Green SJ. Randomized trial of observation versus adjuvant therapy with cyclophosphamide, fluorouracil, prednisone with or without tamoxifen following mastectomy in postmenopausal women with nodepositive breast cancer. J Clin Oncol 1988; 6: 1388-1396.

10 Ingle $\mathbb{N}$, Eversson LK, Wieland HS et al. Randomized trial to evaluate the addition of tamoxifen to cyclophosphamide, 5-fluorouracil, prednison adjuvant therapy in premenopausal women with node-positive breast cancer. Cancer 1989; 63: 1257-1264.

11 Taylor SG, Knuman MW, Sleeper LA et al. Six-year results of the eastern cooperative oncology group trial of observation versus CMFP versus CMFPT in postmenopausal patients with node-positive breast cancer. J Clin Oncol 1989; 7: 879-889.

12. Tormey DC, Gray R, Gilchrist $K$ et al. Adjuvant chemo-homonal therapy with cyclophosphamide, methotrexate, 5-fluorouracil and prednisone (CMFP) or CMFP plus tamoxifen compared with CMF for premenopausal breast cancer patients.

Cancer 1990; 65: 200-206.

13 Boccardo $F$, Rubagotti $A$, Bruzzi $P$ ef al. Chemotherapy versus tamoxifen versus chemotherapy plus tamoxifen in node-positive, oestrogen-receptor-positive breast cancer patients: results of a multicentric Italian study. J Clin Oncol 1990;8 (8): 1310-1320.

14 Henderson IC. Editorial. J Clin Oncol 1990; 8:1297-1300.

15 Riwkin S, Green S, Metch B et all. Adjuvant combination chemotherapy (CMFVP) versus tamoxifen (TAM) versus CMFVP + TAM for postmenopausal women with ER+ operable breast cancer and positive axillary lymph nodes: an Intergroup Study.

Proc Am Soc Clin Oncol 1990; 9: 24 (abstract).

16. Carbone PP. Breast cancer adjuvant therapy. Cancer 1990; 66: 1378-1386. 
17 Fisher $B$, Constantino $J$, Redmond $C$ et al. A randomized clinical trial evaluating tamoxifen in the treatment of patients with node-negative breast cancer who have oestrogen-receptor positive tumours. N Engl J Med 1989; 320: 479-484.

18 Tormey DC, Gelman R, Falkson G. Prospective evaluation of rotating chemotherapy in advanced breast cancer: an Eastern Cooperative Oncology Group Trial.

Am I Clin Oncol 1983; 6: 1-18.

19 Levine $R$, Lippman M, Longo $D$ and Cowan $K$. Effects of oestrogen and tamoxifen on dihydrofolate reductase in gene amplified methotrexate resistant human breast cancer cells. Proc Am Assoc Cancer Res 1983; $24: 173$.

20 Bull JM. A randomized comparative trial of adriamycin versus methotrexate in combination drug therapy. Cancer 1978; 41: 1649-1657.

21 Buzdar $\mathrm{AU}$. Intensive postoperative chemo-immunotherapy for patients with stage II and stage III breast cancer. Cancer 1978; 41: 1064-1075.

22 van Veelen $H$, Willemse $\mathbb{P}$, Tjabbes $T$ et al. Oral high-dose medroxyprogesterone acetate versus tamoxifen. Cancer 1986, 58: 7-13.

23 Gercovich $\mathrm{FG}$. Three consecutive multidisciplinary trials in advanced breast cancer, ASCO 1981; abstract 431.

24 Staging for carcinoma of the breast: In: Beahrs $O$, Henson $D$, Hutter $R$, Myers M, eds. Manual for staging of cancer, 3rd ed. Philadelphia: JB Lippincott, 1988: 145-150.

25 WHO Handbook for reporting resulis of Cancer Treatment. World Health Organization. Geneva, 1979 , p. $16-20$.

26 Hall WJ, Wellner JA. Confidence bands for a survival curve from censored data. Biometrika 1980; 67: 133-143.

27 Therneau TM, Grambsch PM, Fleming TR. Martingalle-based residuals for survival methods. Biometrika 1990; 77: 147-160.

28 Focan $C$, Beauduin $M$. Salamon $E$ et al. Influence of age, node involvement and $\mathrm{CMF}^{-}$ chemotherapy on the outcome of early breast cancer treated with high dose medroxyprogesterone acetate (HD-MPA) as adjuwant hommonotherapy: 5-years results of a randomized trial. In: Sydney E. Salmon, ed. Adjuvant Therapy of Cancer IV: 319-329, 1990. WB Saunders Company, Philadelphia, London, Toronto, Montreal, Sydney, Tokyo.

29 Paterson AH, Hanson $J_{n}$ Pritchard KI et al. Comparison of antiestrogen and progestagen therapy for initial treatment and consequences of their combination for second-line therapy of recurrent breas cancer. Semin Oncol 1990; 17 (suppl 9): 52-62.

30 Muss HB, Case LD, Capizzi RL et al. High versus standard dose megestrol acetate in women with advanced breast cancer: a phase III trial of the Piedmont Oncology Association. J Clin Oncol 1990; 8: 1797-1805.

31 Wallner $J$, Depisch $D$, Hopfer M et al. MDR 1 gene expression and prognostic factors in primary breast carcinomas. Eur J Cancer 1991; 27: 1352-1355.

32. Ramu A, Glaubiger $D$ and Fuks $Z$. Reversal of acquired resistance to doxorubicine in P-388 murine leukemia cells by tamoxifen and other triparanol analogues.

Cancer Res 1984; 44: 4392-4395.

33 Huang Yang C-P, Goei De Pinho S, Greenberger LM, Arceci RJ and Band Horwitz $S$. Progesterone interacts with P-glycoprotein in multidrug-resistant cells in the endometrium of gravid uterus. J Biol Chem 1989; $264: 782-788$.

34. Gagen M, Gochmour D, Young D et al. A randomized trial of metoclopramide and a combination of dexamethason and lorazepam for prevention of chemotherapy-induced vomiting. J Clin Oncol 1984; 2: 696-701.

35. Cox DR and Oakes D. Analysis of survival data. London: Chapman and Hall 1984. 


\section{ADJUVANT CHEMO-HORMONAL THERAPY WITH CYCLOPHOSPHAMIDE, DOXORUBICIN AND 5-FLUOROURACIL (CAF) WITH OR WITHOUT MEDROXYPROGESTERONE ACETATE FOR NODE-POSITIVE CANCER PATIENTS.UPDATE AT 7 YEARS FOLLOW-UP}

PSGJ Hupperets, JAJM Wils, L Volovics, LJ Schouten, MMF Fickers, HNLM Bron, HC Schouten, JJ Jager, JMA de Jong, LVAM Beex, HFP Hillen, GH Blijham 


\section{ADJUVANT CHEMO-HORMONAL THERAPY WITH CYCLOPHOSPHAMIDE, DOXORUBICIN AND 5-FLUOROURACIL (CAF) WITH OR WITHOUT MEDROXYPROGESTERONE ACETATE FOR NODE-POSITIVE CANCER PATIENTS. UPDATE AT 7 YEARS FOLLOW-UP}

\section{LETTER TO THE EDITOR}

The Comprehensive Cancer Center Limburg trial 82-01 is a prospective randomized study to investigate the value of the addition of high-dose medroxyprogesterone acetate (MPA) to CAF chemotherapy in patients with node-positive $(\mathrm{N}+$ ) operable breast cancer $\left(\mathrm{T}_{1-3}, \mathrm{~N}_{1}\right)$. Results of 408 evaluable patients, after a median follow-up of 42 months, have been published in Annals of Oncology ${ }^{1}$ and can be summarized as follows: high dose MPA ameliorates CAF side effects and reduces the risk of metastatic disease in elderly breast cancer patients. Patients $\geq 60$ years benefitted most from MPA treatment in particular if freedom from distant metastases was taken as endpoint $(p=0.02)$. Overall survival (OS) showed a significant advantage in patients $\geq 55$ years $(p=0.002)$. In this letter we report the updated results after a follow-up of 7 years.

After a median follow-up of 84 months the conclusions of the study remain unchanged. No differences in disease-free survival (DFS), distant metastases-free survival and OS were found for the whole group of patients ( $\mathrm{p}$-values were respectively $0.12,0.12$ and 0.18). OS-curves of all patients either or not treated with MPA are shown in figure 1.

Subset analysis revealed a significantly better DFS for the patient group aged between 40 and 60 years compared to the group $\leq 40$ or $>60$ years $(p=0.002)$. This difference is MPA-treatment independent.

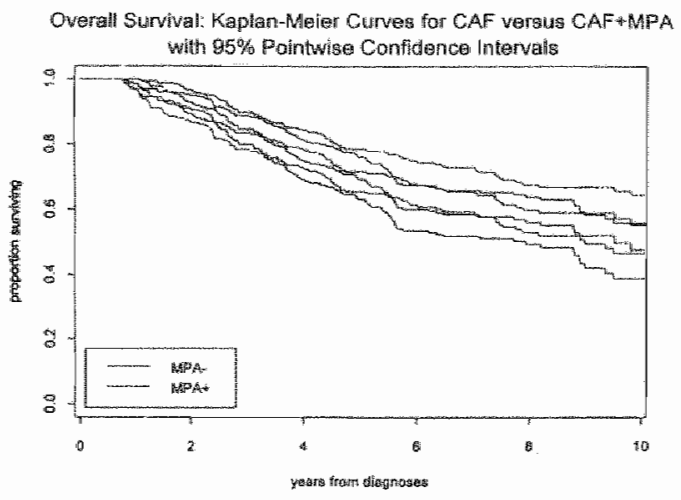

igure 1 Overall Survival (OS) curve for all node-positive patients in both treatment arms. No statistically significant differences between both treatment arms $(\mathrm{p}=0.12)$. For both survival curves $95 \%$ confidence bounds are drawn. 
Patients $\geq 60$ years showed a significantly longer DFS and OS when MPA is added to CAF chemotherapy (p-values respectively 0.05 and 0.008 ) (figure 2).

In contrast; in the subgroup of patients $<40$ years, addition of MPA to chemotherapy proved to be detrimental, the relative risk (RR) for relapse of breast cancer was 1.6 versus 1.1 for patients with or withour MPA respectively, while the RR in the group $\geq 60$ years was lower $(0.7$ versus 1.0$)$ in favour of the MPA-treated group.

In conclusion, this trial suggests a beneficial effect of MPA in combination with chemotherapy in elderly patients ( $\geq 60$ years). This beneficial effect may in part be explained by higher oestrogen-receptor (ER) levels in elderly breast cancer patients. In young breast cancer patients ( $\leq 40$ years) MPA added to adjuvant chemotherapy has a detrimental effect, possibly caused by the protective effect of MPA on ovarian function during CAF chemotherapy ${ }^{2}$, preventing CAF chemotherapy to cause chemotherapy induced ovarian ablation. An alternative explanation may be that MPA reduces the cellular ER- and PgR-content in breast cancer cell lines ${ }^{3}$. This down regulation of ER content in premenopausal breast cancer patients could have a negative influence of endogenous oestrogen on tumour-cell cycle (lower percentage of tumour cells in the proliferative phase) causing less effect of adjuvant chemotherapy on tumour cells in premenopausal patients.

The previously described bone marrow protective effect of MPA ${ }^{1}$ is recently supported by two studies demonstrating in vitro that MPA exerts a cell cycle arrest of haematopoietic precursors protecting them from the toxicity of chemotherapy ${ }^{4}$ and in vivo that MPA induces a mitotic arrest in haematopoietic stem cellss.

The combination of MPA and chemotherapy deserves further exploration in postmenopausal breast cancer patients.

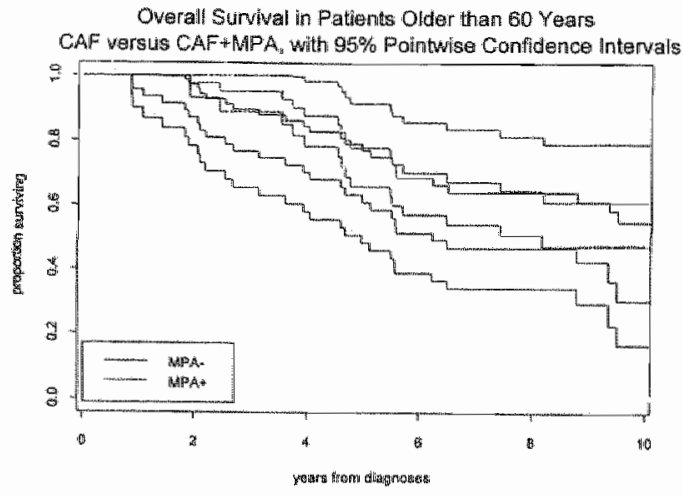

Figure 2 Overall survival (OS) curve for both treatment arms in patients $\geq 60$ and $\leq 70$ years. Differences in favour of the CAF + MPA treatment $\operatorname{arm}(p=0.008)$. For both survival curves $95 \%$ simulareous confidence bounds are drawn. 


\section{REFERENCES}

1 Hupperets PSGJ, Wils J, Volovics J et al. Adjuwant chemohomonall therapy with cyclophosphamide, doxorubicin and 5-Fluorouracil (CAF) with or without medroxyprogesterone acetate for node-positive breast cancer patients.

Ann Oncol 1993; 4: 295-301.

2 Familiari G, Caggiati A, Nottola SA et al. Ultrastructure of human ovarian primordial follicles after combination chemotherapy for Hodgkin's disease.

Hum-Reprod 1993; 8 (2): 2080-2087.

3 Classen $S_{*}$ Possinger $K$, Pelka-Fleischer $R$, Williams $W$. Effect of onapristone and medroxyprogesterone acetate on the proliferation and hormone receptor concentration of human breast cancer cells. J Steroid Biochem Mol Biol 1993; 45 (4): 315-319.

4 Quesada AR, Jimeno IM, Marquez. G, Aracil M. Cell cycle arrest of human haematopoietic progenitors induced by medroxyprogesterone acetate.

Exp Hematol 1993; 21 (11): 1413-1418.

5 Amadori D, Frassineti GL, Flamini E et al. Clinical and laboratory evaluation of the myeloprotective effect of medroxyprogesterone acetate in head and neck cancer.

Eur J Cancer 1992; 28A (8-9): 1331-1334. 


\section{THE PROGNOSTIC SIGNIFICANCE OF STEROID- RECEPTOR ACTIVITY IN TUMOUR TISSUES OF PATIENTS WITH PRIMARY BREAST CANCER}

PSGJ Hupperets, L Volovics, LJ Schouten, JJ Jager, HC Schouten, HFP Hillen, GH Blijham, from the Breast Cancer Study Group, Comprehensive Cancer Center Limburg, Maastricht 


\section{THE PROGNOSTIC SIGNIFICANCE OF STEROID- RECEPTOR ACTIVITY IN TUMOUR TISSUES OF PATIENTS WITH PRIMARY BREAST CANCER}

\section{ABSTRACT}

\section{Introduction}

The prognostic significance of steroid-receptor activity is still under debate. Discrepancies in results are probably due to the small numbers of patients, heterogenous patient populations and short follow-up.

\section{Aim}

In this study we investigated the prognostic significance of oestrogen- and progesteronereceptor (ER and $\mathrm{PgR}$ ) as a continuous variable in a homogeneous patient population.

\section{Results}

The prognostic significance of steroid-receptor activity was studied on 329 node-negative and 320 node-positive unselected breast cancer patients. In node-negative patients, ERvalues of primary tumours between 100 and $400 \mathrm{fmol} / \mathrm{mg}$ protein appeared to be a significant predictor for low risk of recurrence, whereas high ER $(>400)$ revealed an unfavourable prognosis. However, the classical cut-off level of ER $(<10 \mathrm{~mol} / \mathrm{mg}$ ) had no prognostic significance. In patients receiving adjuvant chemotherapy, being the nodepositive breast cancer patients, the classic cut-off value of ER $(10 \mathrm{fmol} / \mathrm{mg}$ protein) predicts significantly for DMFS (distant metastases free survival) and OS (overall survival) only in the first four years of follow-up after diagnosis. PgR is a time dependent prognosticator in node-negative breast cancer patients (cut-off point for $\mathrm{PgR}$ $80 \mathrm{fmol} / \mathrm{mg}$ ). In node-positive breast cancer patients treated with chemotherapy or a combination of chemo- and hormonal-therapy, PgR values lower than $60 \mathrm{fmol} / \mathrm{mg}$ had a worse prognosis.

\section{Conclusion}

The results show the poor performance of standard cul-off points for ER and PgR positivity in predicting prognosis. Better prognosis is related to higher receptor levels but this relation is predominantly time dependent. Moreover, patients with very high ER levels have a prognosis that is worse as compared to intermediate ER levels. This finding might be due to chance and requires independent confirmation. Standard cut-off points for steroid-receptors should be used cautiously to select patients for prognosis. 


\section{INTRODUCTION}

The prognostic significance of measurement of steroid-receptor content i.c. oestrogenreceptor (ER) and progesterone-receptor $(\mathrm{PgR})$ content in breast cancer with regard to recurrence rate is still under debate. Most studies indicate a more favourable prognosis for patients with ER-positive tumours ${ }^{1-26}$. However, in most of these studies the estimated disease-free intervals (DFI) were calculated on few recurrences, which makes statistical analysis less reliable. Studies with more prolonged follow-up suggest that the favourable effect of ER-positivity on recurrence rate decreases gradually in time ${ }^{27-3 i}$. One study ${ }^{32}$ reported on a gradual but sustained risk of relapse during the full length of the follow-up in ER-positive patients, whereas ER-negative patients developed metastases preferentially in the first three years of follow-up. ER-content was not found to be an independent prognostic factor in two multivariate analyses ${ }^{33,34}$. However, in a large scale prospective study $(\mathrm{n}=645) \mathrm{ER}$ and $\mathrm{PgR}$ were found to have an independent prognostic value in postmenopausal patients. In premenopausal patients PgR but not ER appeared to have independent prognostic value $e^{27}$.

Node-negative breast cancer patients, which lack ER's appeared to be at a disadvantage in terms of both disease-free survival (DFS) and overall survivall (OS) ${ }^{10}$. A multivariate analysis of over 1600 stage I breast cancer patients demonstrated that ER-status is the most significant independent predictor of DFS and $\mathrm{OS}^{21}$. However, in a large prospective study of 1157 node-negative patients ER status had only modest prognostic significance ${ }^{24}$. The latter studies ${ }^{21,24}$ included breast cancer patients from various institutions who were treated with different schedules of chemotherapy and surgical procedures.

In the present study the results are shown from an unselected breast cancer patient population in which the diagnostic procedure, locoregional treatment and eventually systemic adjuvant treatment were standardized according to the rules of the protocol. The median follow-up time was 84 and 96 months for node-positive and node-negative patients respectively. Steroid-receptor determination was performed in one single institute and its prognostic value was studied as a continuous variable. In this study, all prerequisites for the proper evaluation of the prognostic significance of steroid-receptors are present.

\section{PATIENTS AND METHODS}

All patients included in this study were entered in the Comprehensive Cancer Center Limburg Study 82-01 for breast cancer patients from May '82 until July "87. Premenopausal and postmenopausal node-negative women $(n=329)$ younger than 71 years with histologically proven infiltrative breast cancer were treated with a modified radical mastectomy or excisional biopsy and selective breast irradiation. From these node-negative patients $91(27.6 \%)$ underwent a conservative breast surgery including axillary node dissection, $235(71.4 \%)$ underwent a modified radical mastectomy with axillary node dissection and $2(0.6 \%)$ a radical mastectomy.

In the same study 320 axillary node-positive breast cancer patients (pre- and postmenopausal but younger than 71 years) were randomized between chemotherapy alone and chemo-endocrine therapy postoperatively ${ }^{46}$. 
Surgical treatment consisted either of conservative breast surgery with axillary node dissection $(n=45)$, modified radical mastectomy with axillary node dissection $(n=268)$ or radical mastectomy $(n=2)$. From 5 patients the surgical procedure could not be detected from the hospital records. All patients who underwent conservative breast surgery had complete radiation of the breast.

Postoperative (adjuvant) treatment was randomly allocated into two arms:

A. Chemotherapy consisting of cyclophosphamide $500 \mathrm{mg} / \mathrm{m}^{2}$, doxorubicin $40 \mathrm{mg} / \mathrm{m}^{2}$ and 5 -fluorouracil $500 \mathrm{mg} / \mathrm{m}^{2}$ on day 1 every 4 weeks.

B. The same chemotherapy in combination with medroxyprogesterone acetate (MPA) daily $500 \mathrm{mg} \mathrm{i.m.} \mathrm{(intramuscularly)} \mathrm{for} 28$ days followed by $500 \mathrm{mg}$ i.m. twice a week for 5 months.

In both arms 6 cycles of chemotherapy were given.

The ER and PgR assays were all performed on histologically proven breast cancer tissues using the dextran-coated charcoal method with multiple-point scatchard-plot analysis ${ }^{38}$. For all the assays the minimum cytosol protein concentration was $2 \mathrm{mg} / \mathrm{ml}$ cytosol. Determination of ER and PgR content was possible in 303/329 and 255/329 nodenegative patients respectively.

In node-positive breast cancer patients ER and $\mathrm{PgR}$ assay was possible in 305/320 and $249 / 320$ patients respectively (table I). PgR assays were only used from 1984, which explains the discrepancy in missing numbers of ER and PgR content.

Table I Distribution of parameters in node-negative and node-positive breast cancer patients.

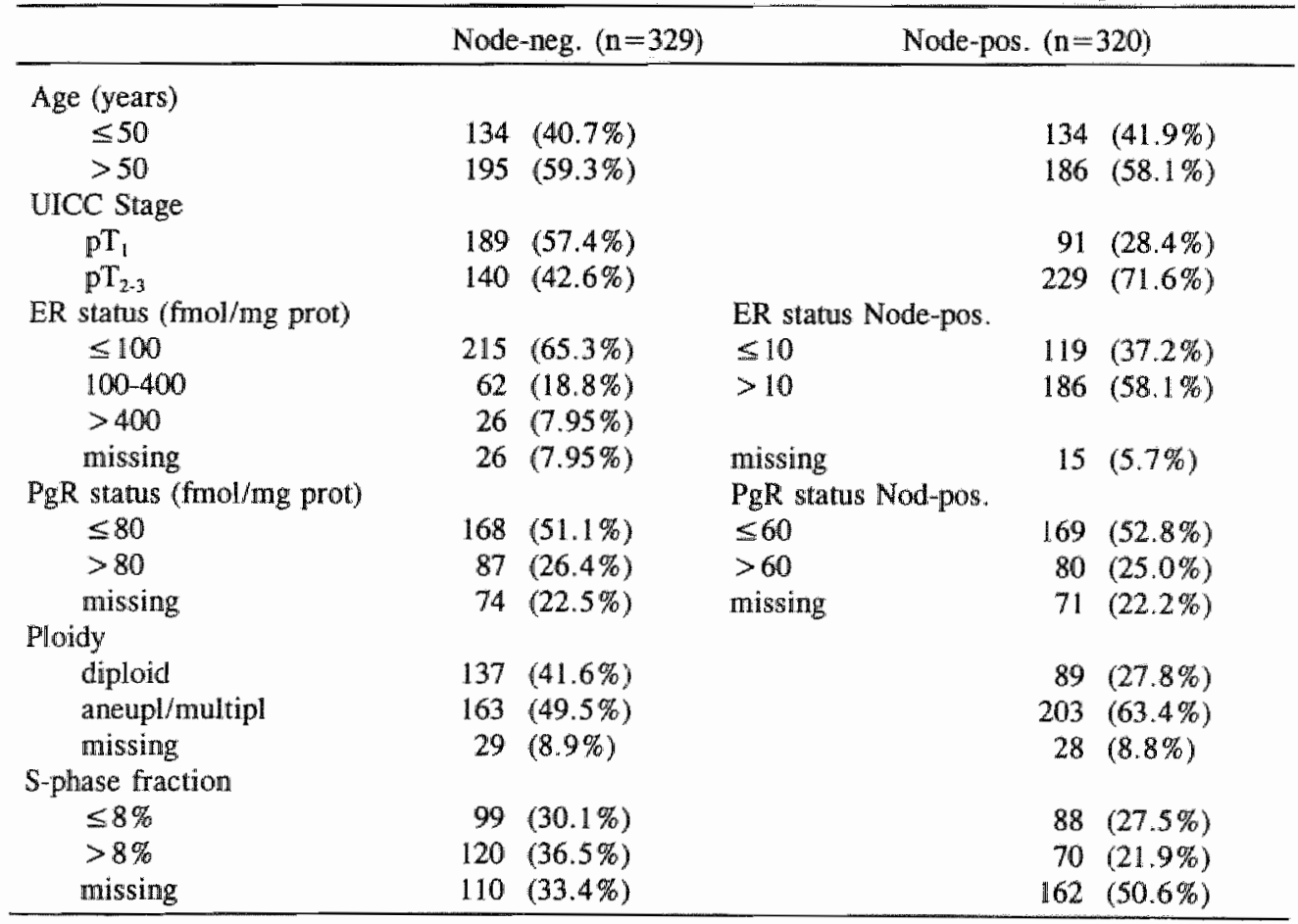


Apart from the clinical parameters that may predict the prognosis also data derived from DNA flow cytometry (FCM) were included in the anallysis. FCM determination of DNA levels and S-phase fraction was performed in nuclei isolated from paraffin embedded

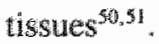

\section{STATISTICAL ANALYSIS}

To investigate the prognostic significance of ER and PgR and other clinical parameters in this study. Kaplan-Meier estimates of survival curves, log rank test for comparing two or more groups and the Cox proportional hazards regression were used. The analyses were done using the statistical packages SAS (SAS Institute Inc., Cary, NC, USA) and S-plus (Statistical Sciences Europe, Oxford, UK).

Routine univariate analyses were done to compare survival curves for quartile and quintile cut-off points. Secondly all parameters were included in a Cox regression analysis with respect to OS and DMFS (distant metastasis-free survival) using standard cut-off points of $10 \mathrm{fmol} / \mathrm{mg}$ protein for ER and PgR. Then the assumptions of the Cox regression model, log-linearity of effect and proportional hazards, were carefully checked using tests based on Schoenfeld residuals and by fitting generalized additive models, plotting survival functions and residuals and by smoothing of partial residuals.

This regression analysis suggested non-linearity and/or time dependence for ER and $\mathrm{PgR}$. In the group of node-negative breast cancer patients non-linearities and time dependence were modelled by taking cut-off points of 100 and 400 for ER to define the patient groups ER $\leq 100,100<E R \leq 400$ and ER $>400$ and a cutpoint of 80 for $\mathrm{PgR}$ to compare patients with $\mathrm{PgR} \leq 80$ to patients with $\mathrm{PgR}>80$ for the first 4 to 5 years after diagnoses and the period after 5 years of follow-up.

In the group of node-positive patients non-linearities and time dependence were adequately described by taking a cut-off point of 10 for $E R$ and comparing ER $\leq 10$ with ER $>10$ and by taking a cut-off point of 60 for PgR and comparing PgR $\leq 60$ with $\mathrm{PgR}>60$.

Here there was a suggestion of time dependence for the effect of ER, showing a difference in survival between the above groups during the first 4 to 5 years of followup, the difference disappearing thereafter.

The proportional hazards regression p-values are the end result of data exploration and should not be interpreted as direct test of a hypotheses of no prognostic effect. The Kaplan-Meier curves and logrank test presented are based on the cut-off points used in the regression analysis.

\section{RESULTS}

Node-negative breast cancer patients

Proportional hazards regression analysis including ER and PgR as potential prognostic factors and using cut-off points of $10 \mathrm{fmol} / \mathrm{mg}$ protein for both did not show any association of ER and PgR with either OS or DMFS in the group of node-negative breast cancer patients. 
For the 329 node-negative patients in the study we summarized these relationships by taking cut-off points for ER at 100 and $400 \mathrm{fmol} / \mathrm{mg}$ protein and comparing the ER $\leq 100$ and the ER $>400$ patient groups with the $100<E R \leq 400$ patient group. The ER $\leq 100$ patients and the ER $>400$ patients had hazard ratios of 2.9 (95\% confidence interval (CI) $1.2-7.1)$, and 3.7 (95\% CI 1.2-11.1), compared with the $100<E R \leq 400$ group of patients for OS. The hazard ratios were 2.1 ( $95 \% \mathrm{CI} 0.95-4.65)$, respectively 2.9 (95\% CI 1.0-8.2) for DMFS. A cut-off point of $80 \mathrm{fmol} / \mathrm{mg}$ protein for PgR suggested that node-negative patients with $\mathrm{PgR} \leq 80$ had a higher risk than node-negative patients with PgR $>80$ up to about 4 to 6 years after diagnosis but a lower risk after about 5 to 6 years after diagnosis, with respect to both OS and DMFS.

The results of the proportional hazards regression analyses are shown in table II. The likelihood ratio test for zero effect of ER on the regression has p-values of 0.02 (OS) and 0.07 (DMFS) and the equivalent test for PgR with time dependence has p-values of 0.002 (OS) and 0.02 (DMFS). Kaplan-Meier curves using these cut-off points for ER and $\mathrm{PgR}$ are shown in figure 1 and 2 and they clearly suggest the above mentioned phenomena.

Table II Multivariate survival analysis (time-dependent) in node-negative breast cancer patients.

\begin{tabular}{|c|c|c|c|c|c|c|}
\hline Parameter & $\mathrm{RR}$ & $\begin{array}{l}\text { DMFS } \\
95 \% \mathrm{CI}\end{array}$ & $p=$ value & $\mathrm{RR}$ & $\begin{array}{l}\text { OS } \\
95 \% \mathrm{Cl}\end{array}$ & $\mathrm{p}$-value \\
\hline $\begin{array}{l}P g R>80 \text { vs } \leq 80 \\
\quad \text { follow-lup }>5 y r\end{array}$ & 3.33 & $1.25-8.87$ & 0.02 & 4.13 & $1.75-9.75$ & 0.0004 \\
\hline$E R \leq 100$ ws $100-400$ & 2.10 & $0.95-4.65$ & 0.06 & 2.89 & $1.18-7.07$ & 0.02 \\
\hline$E R>400$ ys $100-400$ & 2.92 & $1.04-8.19$ & 0.04 & 3.66 & $1.21-11.06$ & 0.02 \\
\hline $\begin{array}{l}\text { Aneupl }+ \text {-multipl } \\
\text { vs dipl. }\end{array}$ & & & & & & \\
\hline $\begin{array}{l}\text { follow-up }<4 \mathrm{yr} \\
\mathrm{pT}_{2.3} \mathrm{vs}^{\mathrm{pT}} \text {, }\end{array}$ & 2.71 & $1.24-5.90$ & 0.008 & 2.47 & $1.24-4.90$ & 0.01 \\
\hline follow-up $>3 \mathrm{yr}$ & 2.42 & $1.21-4.84$ & 0.01 & 2.24 & $1.26-3.99$ & 0.006 \\
\hline
\end{tabular}

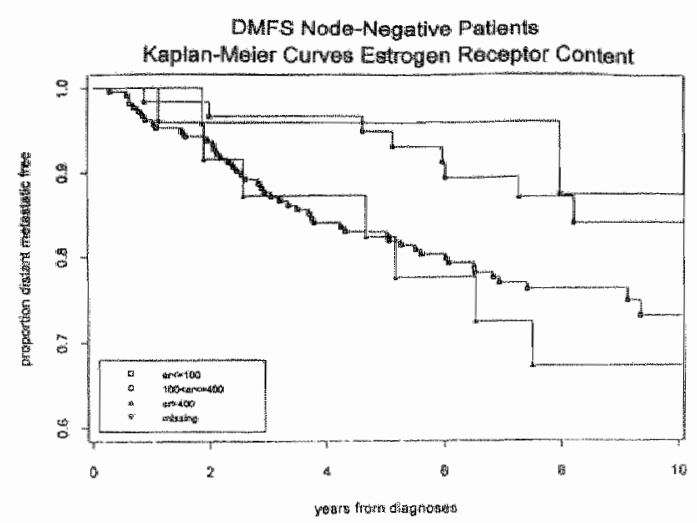

Figure 1 Kaplan-Meier distant metastases-free survival curves in axillary node-negative breast cancer patients.

Cut-off point of oestrogen-receptor (ER) are 100 and $400 \mathrm{fmol} / \mathrm{mg}$ protein. 


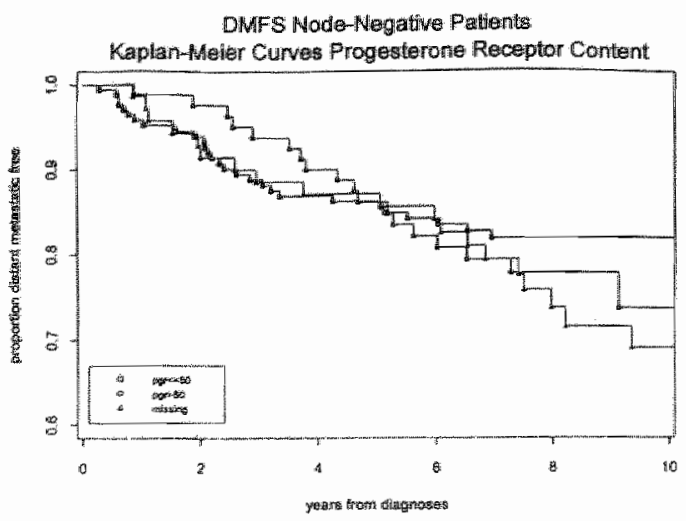

Figure 2 Kaplan-Meier distant metastases-free survival curves in axillary node-negative breast cancer patients.

Cut-off point of progesterone-receptor (PgR) is $80 \mathrm{fmol} / \mathrm{mg}$ protein.

\section{Node-positive breast cancer patients}

In the node-positive breast cancer patients the group of patients with ( $E R \leq 10$ ) did show a hazard rate ratio significantly larger than 1 compared with patients with $(E R>10)$ for the endpoints OS and DMFS but any cut-off point between 10 and approximately 20 would have shown the same result. Again, we found no association of PgR with either OS or DMFS using a cut-off point of 10 .

Data exploration however suggested possible non-linear and/or time dependent effects for both ER and PgR with respect to both OS and DMFS among node-positive breast cancer patients.

For the 320 node-positive patients we summarized the results by taking cut-off points for ER at 10 fmol/mg protein and for $\mathrm{PgR}$ at 60 . With regard to OS the ER $\leq 10$ patients had about twice the risk of the ER $>10$ patients, $p$-value $<0.001$, but there was a definite suggestion that the effect of ER was time dependent, the effect being essentially confined to the first 4 to 6 years after diagnosis. ER $\leq 10$ patients had a hazard ratio of 2.9 (95\% CI 1.8-4.4) compared with ER $>10$ patients during the first 5 years of follow-up, the difference essentially disappearing thereafter. With respect to DMFS there was also a suggestion of a time dependent effect of ER, but weaker than with regard to OS. The $\mathrm{ER} \leq 10$ patients had a hazard ratio of $1.8(95 \% \mathrm{Cl} 1.1-2.9)$ compared to the ER $>10$ patients during the first 4 years of follow-up, the effect again essential disappearing thereatier. With regard to both OS and DMFS the group of patients with $\mathrm{PgR} \leq 60$ had about 1.6 to 1.8 times the risk of $\mathrm{PgR}>60$ patients. The respective $95 \%$ confidence intervals were $1.0-2.7$ and 1.1-3.2. The results of the proportional hazards regression are presented in table III and the Kaplan-Meier curves, figure 3 and 4 , illustrate these effects. 
Table III Multivariate survival analysis (time-dependent) in node-positive breast cancer patients.

\begin{tabular}{|c|c|c|c|c|c|c|}
\hline Parameter & RR & $\begin{array}{l}\text { DMFS } \\
95 \% \mathrm{Cl}\end{array}$ & p-value & RR & $\begin{array}{l}\text { OS } \\
95 \% \mathrm{CI}\end{array}$ & p-value \\
\hline $\begin{array}{l}\mathrm{PgR} \leq 60 \text { vs }>60 \\
\mathrm{ER} \leq 10\end{array}$ & 1.86 & $1.07-3.21$ & 0.03 & 1.64 & $1.01-2.67$ & 0.05 \\
\hline $\begin{array}{l}\text { follow-up }<5 \text { yr } \\
\text { Aneupl }+ \text { multipl. } \\
\text { vs dipl. }\end{array}$ & 1.78 & $1.07-2.94$ & 0.03 & 2.85 & $1.84-4.43$ & 0.0001 \\
\hline $\begin{array}{l}\text { MPA treated pts } \\
\text { SPF }>8 \mathrm{~s}<8 \%\end{array}$ & 4.45 & $1.60-12.41$ & 0.004 & 2.53 & $1.15-5.56$ & 0.02 \\
\hline $\begin{array}{l}\text { SPF }>8 \text { vs } \leq 8 \% \\
\text { MPA treated pts }\end{array}$ & 0.53 & $0.19-1.49$ & 0.04 & 0.37 & $0.15-0.91$ & 0.03 \\
\hline $\begin{array}{l}\text { Age }>50 \mathrm{yr} \\
\text { Pos.axill.nodes }\end{array}$ & 2.86 & $1.50 \cdot 5.45$ & 0.002 & 1.57 & $1.08-2.09$ & 0.02 \\
\hline $\begin{array}{l}4-9 \text { vs } \leq 3 \\
>9 \text { vs } \leq 9\end{array}$ & $\begin{array}{l}1.91 \\
7.01\end{array}$ & $\begin{array}{l}1.24-2.94 \\
3.73-13.16\end{array}$ & $\begin{array}{l}0.003 \\
0.0001\end{array}$ & $\begin{array}{l}2.116 \\
7.47\end{array}$ & $\begin{array}{l}1.45-3.23 \\
4.41-12.65\end{array}$ & $\begin{array}{l}0.0002 \\
0.0001\end{array}$ \\
\hline
\end{tabular}

OS

: overall survival.

DMFS : distant metastasis free survival

RR : relative risk

Cl : confidence interval

$\mathrm{PgR} \quad$ : progesterone-receptor content in fimol $/ \mathrm{mg}$ protein

ER : oestrogen-receptor content in fmol/mg protein

Aneupl : aneuploid primary breast tumours obtained by DNA flow cytometry

Multipl : multiploid primary breast tumours obtained by DNA flow cytometry

SPF : S-phase fraction

MPA : medroxyprogesterone acetate

Pos.axill. nodes : number of tumour containing axillary lymph nodes

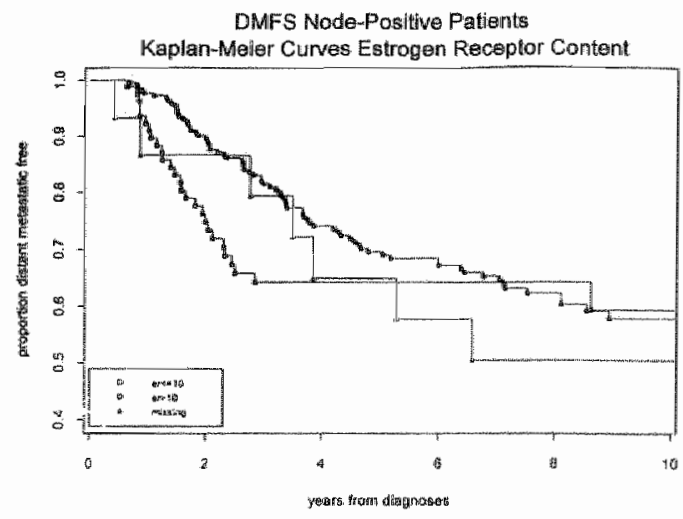

Figure 3 Kaplan-Meier distant metastases-free survival curves in axillary node-positive breast cancer patients. Cutt-off point of ER is $10 \mathrm{fmol} / \mathrm{mg}$ protein. 


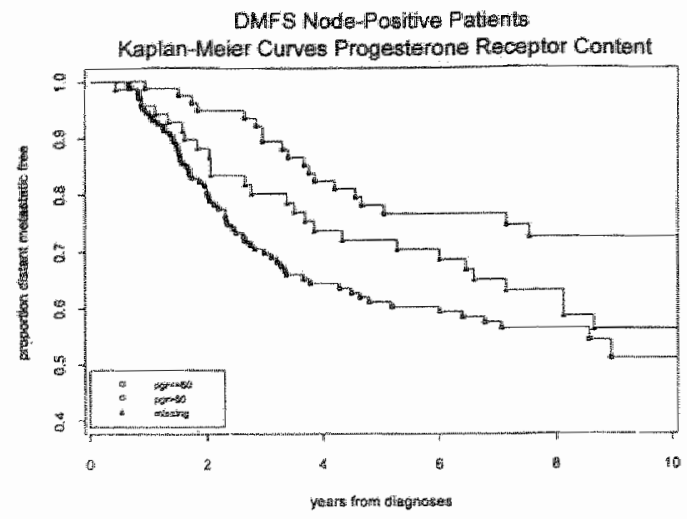

Figure 4 Kaplan-Meier distant metastases-free survival curves in axillary node-positive breast cancer patients. Cut-off point of $\mathrm{PgR}$ is $60 \mathrm{fmol} / \mathrm{mg}$ protein.

\section{DISCUSSION}

The results of the present study suggest an improved DMFS and OS for node-negative breast cancer patients with ER-walues between 100 and 400 fmol/mg protein. Patients with ER-values $<100$ and $>400 \mathrm{fmol} / \mathrm{mg}$ protein had an inferior survival. These results are time independent.

The conclusion on the highest ER group should be drawn with caution because of the low numbers of patients and events in this group. This finding might be due to chance and requires independent confirmation.

Nodle-positive breast cancer patients obviously had a poorer prognosis. In this group an $\mathbb{E R}$ cut-off point of $10 \mathrm{fmol} / \mathrm{mg}$ discriminated between patients with a better and poorer prognosis in the first 5 years after diagnosis. Thereafter, the prognostic impact of the ER. virtually disappears.

A review of results in the literature is not conclusive about ER-content as prognosticator in breast cancer patients ${ }^{1-32}$. In most of these studies cut-off points for ER-content of 10 fmol/mg protein are used and many studies had a relatively short follow-up, and oftem node-negative and node-positive patients are lumped together.

Very few studies addressed the question of other cut-off points for ER in relation to prognosis $^{15.44 .48}$. One study ${ }^{15}$ showed a significant difference in favour of $E R \geq 200$ fmol/mg protein, but the median follow-up period in this study is short (25 months), suggesting the need of a careful interpretation of these results. Thorpe et al. ${ }^{45}$ described in postmenopausal patients with $E R \geq 108 \mathrm{fmol} / \mathrm{mg}$ had a poor prognosis as well as patients with $\mathrm{ER}<10$ fmol/mg, an observation which may be comparable with our results in node-negative breast cancer patients.

A possible explanation of poor prognosis in some patients with high ER-content in the cytosolic fraction can be that in these patients the function of the ER-receptor is impaired. With the biochemical technique the cytosolic ER content is measured. It has been described that in some patients a high cytosolic ER does not reflect a high nuclear ER-content, pointing to an impaired ER-function ${ }^{47}$. Also variants from normal ER have been found with a decreased functional activity ${ }^{49}$. It may be of interest to study ER in the 
cytosolic fraction and immunohistochemically simultaneously on the same tumour specimen to reveal the possibility of such discrepancy.

Progesterone-receptor (PgR) content at a cut-off point of $10 \mathrm{fmol} / \mathrm{mg}$, in our study in node-negative breast cancer patients is not a prognostic factor. The time dependent analysis reveals that node-negative patients with $\mathrm{PgR}$ contents $>80 \mathrm{fmol} / \mathrm{mg}$ protein have an increased risk of dying from their disease after a follow-up time of $>6$ years (RR 4.13). The same phenomenon is seen in this patient group with $\mathrm{PgR}$ content $>80$ fmol/mg protein for DMFS. The relatively low contributions of PgR-content to the final outcome of node-negative breast cancer patients is confirmed by a review of the literature. Small node-negative breast cancer studies reveals that $\mathrm{PgR}$ content can not be considered to be a statistical significant prognosticator ${ }^{31.39-44}$.

Node-positive breast cancer patients with low PgR levels ( $<60$ fmol/mg protein) showed a high risk for distant metastases and death caused by disease. These patients were postoperatively treated with chemotherapy plus or minus medroxyprogesterone acetate as described elsewhere ${ }^{46}$.

In studies including patients receiving adjuvant chemotherapy or chemo- plus hormonaltherapy, PgR predicts the risk of recurrence in a number of these studies ${ }^{27,39,41-44}$. These data indicate that PgR status may be a powerful predictor of the outcome of adjuvant chemotherapy.

In summary this study shows the poor performance of standard ER and PgR cut-off points in predicting clinical outcome. Better prognosis is related to higher steroidreceptor levels but this relation is time dependent. Moreover, patients with very high ER-levels have a worse prognosis compared to intermediate ER-levels.

Standard cut-off points for steroid-receptors should be used cautiously to select patients for prognosis. 


\section{REFERENCES}

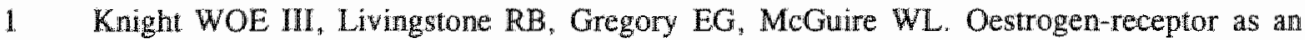
independent prognostic factor for early recurrence in breast cancer.

Cancer Res 37: 4669-4671, 1977.

2 Rich MA, Furmanski P, Brooks SC, and the Breast Cancer Prognostic Study Surgery and Pathology Associates. Prognostic value of oestrogen-receptor determinations in patients with breast cancer. Cancer Res 38: 4296-4298, 1978.

3 Maynard PV, Blamey $\mathbb{R W}$, Elston CW et al. Oestrogen-receptor assay in primary breast cancer and early recurrence of disease. Cancer Res 33:4292-4295, 1978.

4 Allegra JC, Lippman ME, Simon R et al. Association between steroid hormone receptor status and disease free survival in breast cancer. Cancer Treat Rep 63: 1271-1277, 1979.

Cooke T, George D, Shields $\mathrm{R}$ el al. Oestrogen-receptors and prognosis in early breast cancer. Lancet ii: 995-997, 1979.

6 Osborne CK, Yochmowitz MG, Knight WOE III, McGuire WL. The value of oestrogen and progesterone-receptors in the treatment of breast cancer.

Cancer 46: 2884-2888, 1980.

7 Westerberg $\mathrm{H}$, Gustafson SA, Nordenskjöld B et al. Oestrogen-receptor level and other factors in early recurrence of breast cancer. Int J Cancer 26: 429-433, 1980 .

8 Blamey RW, Bishop HM, Blake JRS et al. Relationship between primary breast cancer tumour receptor status and patient surwival. Cancer 46: 2765-2769, 1980.

9 Gapinsky PV, Donegan WL. Oestrogen-receptors and breast cancer: prognostic and therapeutic implications. Surgery 88: 386-393, 1980.

10 Valagussal $P$. DiFronzo $G$, Bignami $P$ et al. Prognostic importance of oestrogen-receptors to select node-negative patients for adjuvant chemotherapy. In: Salmon SE, Jones SE (eds.): Adjuvant Therapy in Cancer III. Grune and Stratton, New York 1981, pp.329-333.

11 Samaan NA, Buzdar Ak, Aldinger KA et al. Oestrogen-receptor: a prognostic factor in breast cancer. Cancer 47: 554-560, 1981.

12 Kinne DW, Ashikari $\mathbb{R}$, Butler $\mathrm{A}$ et al. Oestrogen-receptor protein in breast cancer as a predictor of recurrence. Cancer 47:2364-2367, 1981.

13 Godolphin W, Elwood JM, Spinelli JJ. Oestrogen-receptor quantitation and staging as complementary prognostic indicators in breast cancer: a study of 583 patients.

Int J Cancer 28: 677-683, 1981 .

14 Crowe JP, Hubay CA. Pearson DH et al. Oestrogen-receptor status as a prognostic indicator for stage I breast cancer patients. Breast Cancer Res Treat 2: 171-176, 1982.

15 Neifeld JP, Lawrence WJr, Brown $\mathrm{PW}$ et al. Oestrogen-receptors in primary breast cancer. Arch Surg 25: 581-584, 1982.

16 Paterson AHG, Zuck VP, Szafram $O$ et al. Influence and significance of certain prognostic factors on survival in breast cancer.

Eur J Cancer Clin Oncol 18: 937-943, 1982.

17 Logan LA, Cripps MC, Hirte WE, Rapp EF. The oestrogen-receptor test: a prognostic tool in primary breast cancer. Can J Surg 25: $581-584,1982$.

18 Alanko A, Heinonen E, Scheinin $\mathrm{T}$ et al. Significance of aestrogen and progesteronereceptors, disease free survival and site of metastases on survival of breast cancer patients. Cancer 56: 1696-1700, 1985.

19 Pearson $\mathrm{OH}$, Hubay $\mathrm{CA}$, Gordon $\mathrm{NH}$ et al. Oestrogen-receptors and prognosis in breast. cancer. In: Hormonally Responsive Tumours, New York, Academic Press, 1985, pp. $487-503$. 
20 McGuire WL, Clark GM, Dressler LG et al. Role of steroid hormone receptors as prognostic factors in primary breast cancer. J Natl Cancer Inst Monogr 1: 19-23, 1986.

21 McGuire WL. prognostic factors in primary breast cancer.

Cancer Surveys 5: $527-536,1986$.

22 Kallioniemi OP, Blanco G, Alawaikko $M$ et al. Tumour DNA ploidy as an independent prognostic factor in breast cancer. Br J Cancer 56: 637-642, 1987.

23 Williams MR, Todd JH, Ellis 10 et al. Oestrogen-receptors in primary and advanced breast cancer: an eight year review of 704 cases. Br I Cancer 55: 67-73, 1987.

24 Fisher B, Redmond C, Fisher ER et al. Relative worth of oestrogen and progesteronereceptor and pathologic characteristics of differentiation as indicators of prognosis in node-negative breast cancer patients: findings from the National Surgical Adjuvant Breast and Bowel Protocol B-06. J Clin Oncol 6: 1076-1087, 1988.

25 Chevallier $B$, Heintzmann F, Mosseri $V$ et al. Prognostic value of oestrogen and progesterone-1receptors in operable breast cancer. Cancer 62: 2517-2524, 1988.

26 Sigurdsson $\mathrm{H}$, Badetorp $\mathrm{B}$, Borg $\mathrm{A}$ et al. Indicators of prognosis in node-negative breast cancer. N Engl J Med 322: 1045-1053, 1990.

27 Hahnel $R$, Woodings $T$, Vivian AB. Prognostic value of oestrogen-receptors in primary breast cancer. Cancer $44: 671-675,1979$.

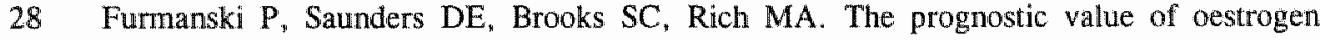
determinations in patients with primary breast cancer: an update. Cancer 46: 2794-2796, 1980.

29 von Maillot $\mathrm{K}$, Horke W, Prestele $\mathrm{H}$. Prognostic significance of steroid-receptor content in primary breast cancer. Arch Gynaecol 231: 185-190, 1982.

30 Howat JMT, Barnes DM, Harris M, Swindell R. The association of cytosol oestrogen and progesterone-receptors with histological features of breast cancer and early recurrence of disease. Br J Cancer 47:629-640, 1983.

31 Saez $S$, Cheix $\mathbb{F}$, Asselain B. Prognostic value of oestrogen and progesterone-receptors in primary breast cancer. Breast Cancer Res Treat 3: 345-354, 1983.

32 Raemaekers JMM, Beex LVAM, Koenders AJM et al. Disease free interval and oestrogen-receptor activity in tumour tissue of patients with primary breast cancer: an analysis after long-term follow-up. Breast Cancer Res Treat 6: 123-130, 1985.

33 Todd JH, Dowle CS, Williams WR et al. Conformation of a prognostic index in breast cancer. Br J Cancer 56: 482-492, 1987.

34 Clark GM, Dressler LG, Owens MA et al. Prediction of relapse or survival in patients with node-negative breast cancer by DNA flow cytometry.

N Engl J Med 320:627-633, 1989.

35 Pichon MF, Pallud C, Brunet M, Milgrom E. Relationship of presence of progesteronereceptors to prognosis in early breast cancer. Cancer Res $40: 3357-3360,1980$.

36 Clark GM, McGuire WL, Hubay CA et al. Progesterone-receptor as a prognostic factor in stage II breast cancer. N Engl J Med 309: 1343-1347, 1983.

37 Thorpe SH, Rose C, Rasmussen BB et al. Prognostic value of steroid-receptors: multivariate analysis of systematically untreated patients with node-negative primary breast cancer. Cancer Res 47: 6126-6133, 1987.

38 Scatchard $G$. The attraction of proteins for small molecules and ions. Am NY Acad Sci 51: $660-672,1949$.

39 Mason BH, Holdaway IM, Mullins RR et al. Progesterone and oestrogen-receptor as prognostic variables in breast cancer. Cancer Res 43: 2985-2990, 1983.

40 Di Fronzo G, Cappelletti V, Coradini D et al. Prognostic significance of progesteronereceptors alone in association with oestrogen-receptors in human breast cancer.

Tumori 70: $159-164,1984$. 
41 Kohail HH, Elias EG, El-Nowiem SA et al: A mulifactorial analysis of steroid hormone receptors in stage I and II breast cancer. Ann Surg 201: 611-617, 1985 .

42 Fisher $B$, Redmond CK, Wickerham DL et al. Relation of oestrogen and/or progesterone-receptor content of breast cancer to patient outcome following adjuvant therapy.

Breast Cancer Res Treat 3: 355-365, 1983.

43 Howell $A$, George WD, Crowther $D$ et al. Controlled trial of adjuvant chemotherapy with cyclophosphamide, methotrexate and fluorouracil for breast cancer.

Lancet ii: $307-311,1982$.

44 Raemaekers JJM, Beex LVAM, Pieters GFFM et al. Progesterone-receptor activity and the relapse-free survival in patients with primary breast cancer: the role of adjuvant chemotherapy. Breast Cancer Res Treat 9 (3): 191-199, 1987.

45 Thorpe SM, Christensen IJ, Rasmussen BB, Rose C. Short recurrence-free survival associated with high oestrogen-receptor levels in the natural history of postmenopausal, primary breast cancer. Eur J Cancer 29A (7): 971-977, 1993.

46 Hupperets PSGJ, Wils $J$, Volovics $L$ et al. Adjuvant chemohormonal therapy with cyclophosphamide, doxorubicin and 5-fluorouracil (CAF) with or without medroxyprogesterone acetate for node-positive breast cancer patients.

Ann Oncol 4: 295-301, 1993.

47 Brown M. Oestrogen-receptor molecular biology.

Hematology/Oncology Clinics of North America 8: 101-112, 1994.

48 Hill SM, Fuqua SAW, Chamness GC et al. Oestrogen-receptor expression in human breast cancer associated with an oestrogen-receptor gene restriction fragment length polymorphism. Cancer Res 49: 145-148, 1989.

49 McGuire WL, Chamness CG, Fuqua SAW. Oestrogen-receptor variants in clinical breast cancer. Mol Endo 5; 1571-1577, 1991.

50 Hedley DW. Flow cytometry using paraffin-embedded tissue: five years on. Cytometry 10: 229-241, 1989.

51 Vindel $6 \mathrm{y}$ LL. Christensen U, Nissen NI. A detergent trypsin method for the preparation of nuclei for flow cytometric DNA analysis. Cytometry $3: 323-327,1983$. 


\section{THE PROGNOSTIC VALUE OF FLOW CYTOMETRY IN WOMEN WITH NODE- NEGATIVE PRIMARY BREAST CANCER}

PSGJ Hupperets, L Volovics, B Schutte, LJ Schouten, HC Schouten, HFP Hillen and GH Blijham, on behalf of the Breast Cancer Study Group from the Comprehensive Cancer Center Limburg 


\title{
THE PROGNOSTIC VALUE OF FLOW CYTOMETRY IN WOMEN WITH NODE-NEGATIVE PRIMARY BREAST CANCER
}

\begin{abstract}
There is a need for a prognostic model in node-negarive breast cancer patients to individualize post-operative therapy. DNA flow cytometry (FCM) has addressed this problem but results have been variable.

Our results on DNA flow cytometry in a homogeneously treated and diagnosed nodenegative breast cancer patient population $(n=329)$, after a median follow-up of 96 months shows ploidy being a time dependent prognostic factor. Patients with aneuploid and multiploid DNA content have a relative risk of 2.9 on distant metastases compared to diploid patients during the first 4 years of follow-up. S-phase fraction was no independent prognostic factor in multivariate analysis.

Apart from ploidy, steroid-receptor status shows a complex but a strong relation with clinical outcome. However, prospective clinical trials in which high risk patients, based on these factors are randomised to either adjuvant treatment or observation, are justifiable.
\end{abstract}

\section{INTRODUCTION}

Approximately 50 to $60 \%$ of patients with breast cancer have disease apparentlly confined to the breast without axillary nodal involvement. The proportion of node-negative breast cancer will probably increase with the implementation of breast screening programs ${ }^{2}$. Although patients with node-negative breast cancer are considered to have a good prognosis, the rate of recurrence in these patients is approximatelly $30-40 \%$ and the 10-year survival rate is around $75 \%{ }^{3}$.

The use of adjuvant therapy in patients with node-negative breast cancer is still controversial ${ }^{4-9}$. There is a tendency to apply adjuvant therapy in node-negative patients with two or more unfavourable prognostic factors. Unfavourable factors can be defined as tumour size $>2 \mathrm{~cm}^{10-14}$, histologic grade II and III', high cell kinetic activity determined by thymidine labelling ${ }^{16,17}$ and more recenty aneuploidy or high S-phase fraction (SPF) determined by DNA flow cytometry ${ }^{18.26,27,28}$.

The goal of this retrospective study is to use DNA flow cytometry in a homogeneously diagnosed group of patients to assess ploidy and S-phase fraction and to evaluate the clinical importance of these measurements in combination with other prognostic factors in order to identify patients with node-negative breast cancer who may have a high or low risk for recurrence. 


\section{PATIENTS AND METHODS}

Premenopausal and postmenopausal women younger than 71 years with histologically proven infiltrative breast cancer without axillary nodal involvement were included. All patients were treated with a modified radical mastectomy or lumpectomy with postoperative breast irradiation. Lumpectomy was performed in patients with a primary tumour equal to or smaller than $3 \mathrm{~cm}$. Postlumpectomy breast irradiation consisted of $50.00 \mathrm{~Gy}$ to the total breast with a boost of $14.00 \mathrm{~Gy}$ to the operated region.

Patients with carcinoma in situ, bilateral breast cancer, inflammatory breast cancer or $T_{4}$ primary tumour were ineligible. Eligibility criteria included a normal bone scan, no previous or concomitant malignancy (except curatively treated (non-melanoma) skin cancer or cervix carcinoma in situ) and no pregnancy or lactation at the time of diagnosis of breast carcinoma. The patients were staged according to the TNM system adapted by both the Union Internationale Contre le Cancer and the American Joint Commission on Cancer Staging ${ }^{29}$.

\section{REGISTRATION}

Registration was done by telephone at the office of the Comprehensive Cancer Center Limburg. Registration of patients occurred preoperativelly but only patients with postoperative negative nodes were analyzed for this report. All the data were entered into a computerized data base and verified to minimize errors in data entry.

\section{PATIENT ACCRUAL AND TREATMENT}

Accrual was from May, 1982 through July, 1987. Threehundred twenty nine patients fulfilled the entry criteria and were treated according to the protocol. Surgical treatment consisted either of conservative breast surgery with axillary node dissection $(n=91$; $27.7 \%)$, modified radical mastectomy with axillary node dissection $(\mathrm{n}=236 ; 71.7 \%)$ or radical mastectomy $(n=2 ; 0.6 \%)$. Postoperative locoregional irradiation was given to patients with central or medial localized breast cancer (parasternal radiation field) $(\mathrm{n}=121 ; 36.8 \%)$ and in patients with microscopically irradical operation (chest wall irradiation $)(n=25 ; 7.6 \%)$. Patients with conservative breast surgery with axillary node dissection were irradiated on the operated breast $(n=91 ; 27.7 \%)$. No adjuvant chemotherapy or hormonal therapy was given to these patients. The clinical characteristics are shown in table I. The median follow-up time of the 329 patients is 96 months. As of their last recorded follow-up evaluation, 251 patients were allive (76.3\%) and 246 patients were free of distant metastases (74.7\%). 


\section{PATIENT EVALUATION}

Follow-up included a history and physical examination every 3 months during the first 2 years, every 4 months in the third year, every 6 months in the fourth and fifth year and every 12 months thereafter. In the same frequency blood counts, alkaline phosphatase, gamma-glutamic transferase, lacto-dehydrogenase, calcium and erythrocyte sedimentation rate were examined. Chest radiographs and mammography were performed every year.

\section{HISTOLOGICAL EXAMINATION AND LABORATORY ASSAYS}

Tumour size was taken from the pathological size after surgery. The histological grade was determined by the method of Bloom and Richardson ${ }^{30}$. Oestrogen- and progesteronereceptor contents were assayed with the dextran-coated charcoal method with Scatchard analysis and calculation according to the method of Lowry ${ }^{31.32}$. A level of at least 10 fmol/mg cytosol protein was considered as receptor positive.

Flow cytometric determination of DNA levels was performed in nuclei isolated from paraffin-embedded tissue ${ }^{33,34}$. Fifty $\mu \mathrm{m}$ sections were cut from formalin-fixed paraffinembedded tissue blocks of the primary tumours. An adjacent $5 \mu \mathrm{m}$ section was cut for histological control. DNA content was measured by the method of Vindel $6 \mathrm{w}^{35}$. Tumours with a single G1 peak were considered to be diploid, whereas evidence of an additional peak indicated aneuploidy. DNA index (DD) was calculated as the ratio of aneuploid to diploid G1/0 peak level. Histograms with coefficients of variation less than $8 \%$ were considered of good quality. The proliferative activity (SPF) was calculated by counting the number of cells between the inclination points of the descending G1 peak and the ascending G2/M peak ${ }^{32,36}$. In cases of less than $30 \%$ admixture of diploid cells, the percentage of aneuploid S-phase cells was calculated without corrections for the presence of diploid S- and G2/M-phase cells. In case of more than $30 \%$ admixture of diploid cells in overlap in diploid and hyperdiploid histograms the percentage of S-phase cells was not calculated.

\section{STATISTICAL ANALYSIS}

To investigate the prognostic significance of the clinical parameters included in the study, Kaplan-Meier estimates of survival curves, logrank tests for comparing two or more groups and the Cox proportional-hazards regression model were used.

All analyses were done using the statistical packages SAS (SAS Institute Inc., Cary, NC, USA) and S-PLUS (Statistical Sciences Europe, Oxford, UK).

First, correlations of covariates were studied using Kendall's tau correlations. Routine univariate analyses were done to compare survival curves using quartile and quintile cutoff points for the prognostic variables with respect to the end points 'overall survival" (OS) and "distant metastatic free survival" (DMFS). Secondly, all prognostic variables were included in a Cox regression analysis with respect to these endpoints. For every variable the assumptions of the Cox regression model, i.e. proportional hazards and loglinearity of effect, were checked. 
The proportional hazards assumption was checked through different graphical plots and using tests based on Schoenfeld residuals. Log-linearity of effects was checked through generalized additive modelling and smoothing of partial residual plots.

With regard to both OS and DMFS there was a definite suggestion of non-proportionality for the effect of progesterone-receptor content, ploidy and pT-status and of non-linearity of effect for oestrogen-receptor content. The non-linearity of oestrogen-receptor content suggested taking cut-off points at approximately 100 and $400 \mathrm{fmol} / \mathrm{mg}$ protein. The plots also suggested some non-linearity of progesterone-receptor content, S-phase percentage and age: these seemed to be adequately modelled by taking cut-off points at respectively $80 \mathrm{fmol} / \mathrm{mg}$ protein, $8 \%$ and 50 years of age.

Non-proportionality was dealt with by fitting time-dependent modells for progesteronereceptor content, ploidy and $\mathrm{pT}$-status. Differences between $\mathrm{pT}_{2}+\mathrm{pT}_{3}$ and $\mathrm{pT}_{1}$ seemed to be 'delayed' for approximately 3 years, the difference between aneuploid/multiploid and diploid seemed to diminish after approximately 5 years and there seems to be a 'switch' in relative risk of progesterone-receptor content $>80(\mathrm{PgR}>80)$ in comparison with $(\mathrm{PgR} \leq 80)$ at approximately 4 years for DMFS and approximately 5 years for OS.

\section{RESULTS}

Flow cytornetry was performed in 300 out of 329 tumour specimens (91.2\%). From 29 cases no tumour specimens were available $(n=20)$ or histograms were uninterpretable $(n=9)$. The main characteristics of the missing cases did not differ significantly from those of the patients with interpretable histograms nor was the relapse-free survival or overall survival different for these 29 patients. Overall clinical characteristics are listed in table $I$.

In 219 of these $300(73 \%)$ patients it was possible to determine the SPF $666.6 \%$ of the total number of node-negative breast cancer patients). Of the analyzed patients $137 / 300$ $(45.5 \%)$ are diploid whereas $149 / 300(49.5 \%)$ are aneuploid and $14 / 300(5 \%)$ multiploid. 
Table I Clinical and flow cytometric characteristics of 329 patients with node-negative breast cancer

\begin{tabular}{lcc}
\hline & Number & Percentage \\
\hline Age (years) & 134 & \\
$\leq 50$ & 195 & 40.7 \\
$>50$ & & 59.3 \\
UICC stage & 189 & 57.4 \\
$\mathrm{pT}_{1}$ & 140 & 42.6 \\
$\mathrm{pT}_{2-3}$ & & \\
ER starus (fmol/mg protein) & 215 & 65.3 \\
$\leq 100$ & 62 & 18.8 \\
$100-400$ & 26 & 7.95 \\
$>400$ & 26 & 7.95 \\
missing & & \\
PR status (fmol/mg protein) & 168 & 51.1 \\
$\leq 80$ & 87 & 26.4 \\
$>80$ & 74 & 22.5 \\
missing & & \\
Ploidy & 137 & 41.6 \\
diploid & 163 & 49.5 \\
aneuploid + multiploid & 29 & 8.9 \\
missing & & \\
SPF (\%) & 99 & 30.1 \\
$\leq 8$ & 120 & 36.5 \\
$>8$ & 110 & 33.4 \\
missing & &
\end{tabular}

\section{CORRELATIONS OF COVARIATES}

Age correlated weakly with oestrogen-receptor content $(r=0.22, p=0.003)$. A slightly stronger correlation was found between $E R$ and $\operatorname{PgR}(r=0.28, p=0.001)$. SPF correlated with the aneuploid status $(r=-0.26, p=0.01)$. SPF also showed a weak correlation with age $(r=-0.20, p=0.05)$ and SPF was also correlated with ER-content $(r=-0.22$, $\mathrm{p}=0.03$ ). There were no significant correlations between all other variables.

\section{UNIVARIATE AND MULTIVARIATE ANALYSIS OF SURVIVAL}

The results of univariate analysis are shown in table II. ER-content and pT-status are the most important variables in predicting OS. Statistically significant differences can be found between the different ER-groups (ER $\leq 100 ; 100<\mathrm{ER} \leq 400$ and $E R>400$ ). There is a significant better overall survival in the intermediate $(100<E R \leq 400 \mathrm{fmol} / \mathrm{mg}$ protein) oestrogen-receptor group comparing the OS in the ER groups $\leq 100$ and $>400$. Diploid patients have a better OS in comparison with non-diploid patients $(\mathrm{p}=0.02)$. 
Table II Univariate analysis of prognostic variables in 329 node-negative breast cancer pattents: 7 years OS and DMFS

\begin{tabular}{|c|c|c|c|c|c|}
\hline \multirow[b]{2}{*}{ Parameter } & \multirow[b]{2}{*}{ No pts. } & \multicolumn{2}{|c|}{ DMFS } & \multicolumn{2}{|c|}{ OS } \\
\hline & & $\begin{array}{c}\text { No events } \\
\text { obs. }\end{array}$ & p-walue & $\begin{array}{c}\text { No ewents } \\
\text { obs. }\end{array}$ & $\mathrm{p}$-value \\
\hline \multicolumn{6}{|l|}{ ploidy } \\
\hline $\begin{array}{l}\text { diploíd } \\
\text { aneupl\& }\end{array}$ & 1.37 & 24 & & 18 & \\
\hline multipl & 163 & 36 & & 41 & \\
\hline missing & 29 & 5 & 0.47 & 7 & 0.02 \\
\hline \multicolumn{6}{|l|}{ Size } \\
\hline $\mathrm{pT}_{\mathrm{I}}$ & 189 & 31 & & 32 & \\
\hline $\mathrm{pT}_{2-3}$ & 140 & 34 & 0.08 & 34 & 0.11 \\
\hline \multicolumn{6}{|l|}{ ER-status } \\
\hline$\leq 100$ & 215 & 48 & & 51 & \\
\hline $100<\mathrm{ER} \leq 400$ & 62 & 8 & & 6 & \\
\hline$>400$ & 26 & 7 & & 7 & \\
\hline missing & 26 & 2 & 0.08 & 2 & 0.04 \\
\hline \multicolumn{6}{|l|}{ PgR status } \\
\hline$\leq 80$ & 168 & 28 & & 28 & \\
\hline$>80$ & 87 & 18 & & 19 & \\
\hline missing & 74 & 19 & 0.44 & 19 & 0.47 \\
\hline \multicolumn{6}{|l|}{ Age } \\
\hline$\leq 50$ & 134 & 30 & & 33 & \\
\hline$>50$ & 195 & 35 & 0.25 & 33 & 0.09 \\
\hline \multicolumn{6}{|l|}{ S-phase } \\
\hline$\leq 8$ & 99 & 19 & & 16 & \\
\hline$>8$ & 120 & 26 & & 26 & \\
\hline missing & 110 & 20 & 0.87 & 24 & 0.47 \\
\hline
\end{tabular}

DMFS analysis shows the same trends for ER-content but the differences are not statistically significant at the $5 \%$ level. There is a suggestion $(\mathrm{p}=0.08)$ that the group of patients with an extreme high ER-content ( $>400 \mathrm{fmol} / \mathrm{mg}$ protein) have a higher relapse rate compared to patients from the intermediate group.

Kaplan-Meier curves on overall survival and distant metastasis-free survival for ploidy and SPF are shown in figure $1 \mathrm{a}, 1 \mathrm{~b}, 2 \mathrm{a}$, and $2 \mathrm{~b}$.

Multivariate analysis using Cox's proportional Hazards model is done to assess the effects of ploidy, SPF, pT stage, age, and steroid-receptor status on time to relapse and survival. Results are shown in table III. Ploidy status is a time dependent prognostic factor for DMFS; during the first five years of follow-up aneuploid and multiploid breast cancer patients had a relative risk (RR) of 2.7 on distant metastases $(p=0.02)(95 \%$ confidence interval (CI) $1.24-5.90$ ) compared to diploid breast cancer patients. 


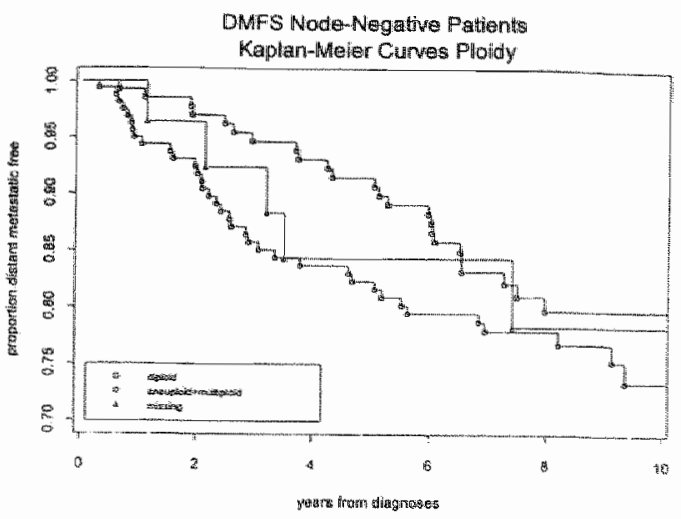

Figure 1a Distant metastases free survival (years) curve for diploid $(n=137)$ and non-diploid $(n=163)$ node-negative breast cancer patients (p-value 0.09).

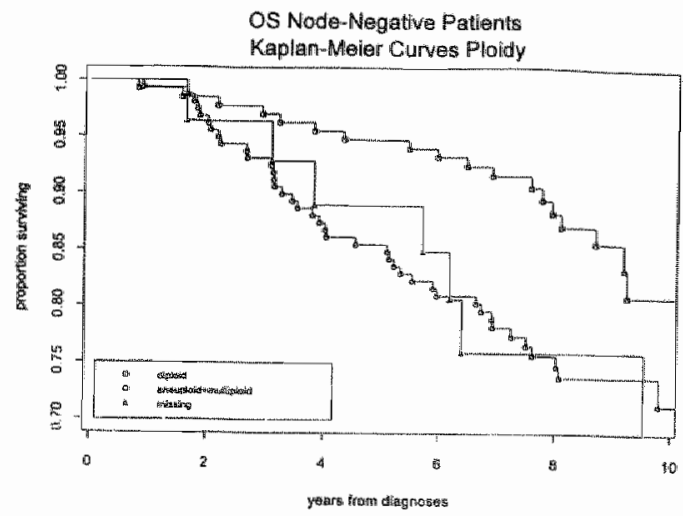

Figure $1 \mathrm{~b}$ Overall survival (years) curve for diploid and non-diploid node-negative breast cancer patients (p-value 0.02).

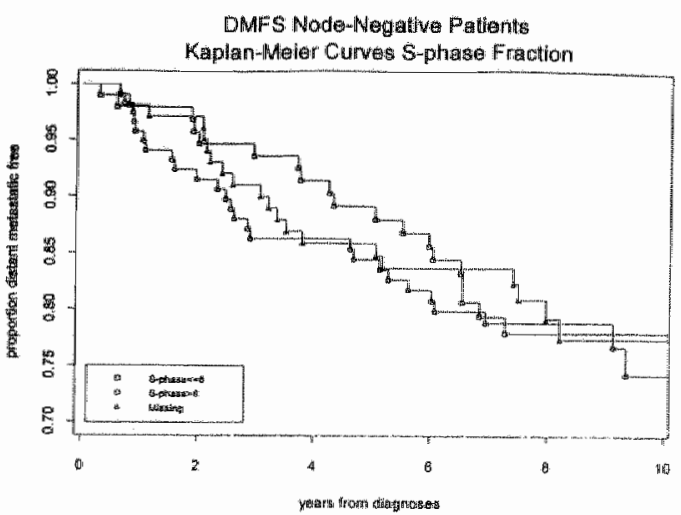

Figure 2a Distant metastases free survival (years) curve for S-phase (SPF) groups $\leq 8 \%$ ( $n=99$ ) and $\mathrm{SPF}>8 \%(\mathrm{n}=120)(\mathrm{p}$-value 0.87$)$. 


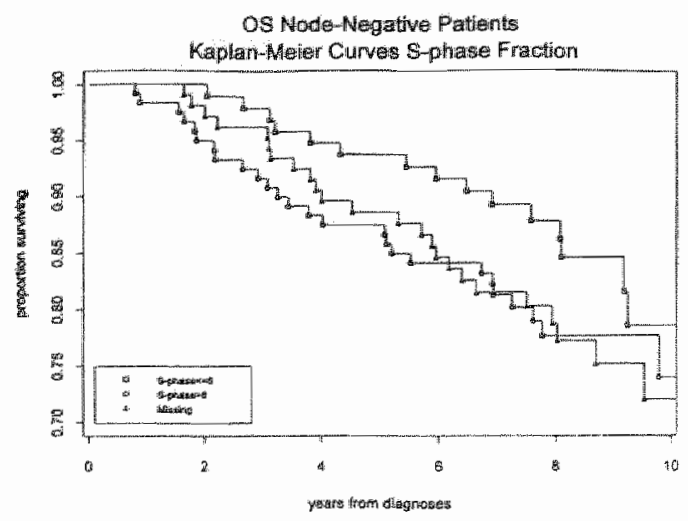

Figure $2 \mathrm{~b}$ Overall survival (years) cure for SPF groups $\leq 8 \%$ and $>8 \%$ (p-value 0.47 ).

Concerning overall survival (OS) ploidy status revealed to be a time independent prognosticator, meaning aneuploid and multiploid patients have a statistically significant shorter OS time compared to diploid patients (RR 2.5, $\mathrm{p}=0.01 ; 95 \% \mathrm{Cl} 1.24-4.90$ ). SPF is no independent prognostic factor in multivariate analysis, neither for DMFS nor OS in this node-negative breast cancer study. ER-content $\leq 100 \mathrm{fmol} / \mathrm{mg}$ protein and ERcontent $>400 \mathrm{fmol} / \mathrm{mg}$ protein are important prognosticators for OS and in a lesser extent for DMFS. There is a suggestion that patients with $\mathrm{PgR} \leq 80 \mathrm{fmol} / \mathrm{mg}$ protein have a higher risk for distant metastases during the first 4 years of follow-up, compared to the $\mathrm{PgR}>80$ group, while this risk after 4 years of follow-up is significantly higher for patients with $\mathrm{PgR}>80$ (OS: RR 4.13; $95 \% \mathrm{Cl} 1.75-9.75$ and distant metastases $\mathrm{RR}$ $3.3 ; 95 \%$ CI $1.25-8.87$ ).

$\mathrm{pT}_{2}$ and $\mathrm{pT}_{3}$ primary tumours had an impaired survival compared to $\mathrm{pT}_{1}$ tumours, but the DMFS differences were marginally statistically significant $(p=0.06, \mathrm{RR} 2.2 ; 95 \% \mathrm{CI}$ 1.26-3.99).

The age of node-negative breast cancer patients did not appear to be an independent prognosticator. A combination of variables for unfavourable prognosis are $\mathrm{pT}_{2+3}+$ aneuploidy and multiploidy, $\mathrm{pT}_{2+3}+\mathrm{PgR} \leq 80, \mathrm{ER} \leq 100$ and $\mathrm{pT}_{2+3}+\mathrm{ER}>400$. Together these groups contain $110 / 329(33 \%)$ of patients. Their 5-year survival rate is $78 \%$ as compared to $92 \%$ for the other 219 patients not having these unfavourable characteristics. 
Table III Multivariate analysis (Cox proportional Hazards regression) of prognostic covariates of survival in 329 node-negative breast cancer patients followed-up for a median of 96 months

\begin{tabular}{|c|c|c|c|c|c|c|c|c|c|}
\hline & & & & & & & DA & & \\
\hline & $B$ & p-value & $\mathrm{RR}$ & $95 \% \mathrm{CI}$ & & 13 & p-value & $\mathrm{RR}$ & $95 \% \mathrm{Cl}$ \\
\hline $\mathrm{pT}_{2,3} / \mathrm{z}$ & 0.81 & 0.006 & 2.24 & $1.26-3.99$ & $\mathrm{pT}_{2,3} />3 \mathrm{yr}$ & 0.88 & 0.01 & 2.42 & $1.21-4.84$ \\
\hline $\mathrm{An}+$ multi & 0.90 & 0.01 & 2.47 & $1.24-4.90$ & $A n+$ mult $1<5 y$ & I 1.00 & 0.01 & 2.71 & $1.24-5.90$ \\
\hline$E R \leq 100$ & 11.06 & 0.02 & 2.89 & $1.18 \times 7.07$ & $\mathrm{ER} \leq 100$ & 0.74 & 0.07 & 2.10 & $0.94-4.65$ \\
\hline $\mathrm{ER}>400$ & 11.30 & 0.02 & 3.66 & $1.21-11.06$ & $\mathrm{ER}>400$ & 1.07 & 0.04 & 2.92 & 1.048 .19 \\
\hline $\mathrm{PgR}>80 /<5 \mathrm{yn}$ & $r-0.54$ & 0.29 & 0.58 & $0.22-1.57$ & $\mathrm{PgR}>80 /<4 \mathrm{yr}$ & -0.21 & 0.62 & 0.81 & $0.35-1.86$ \\
\hline $\mathrm{PgR}>80 />5 \mathrm{yr}$ & 1.42 & 0.001 & 4.13 & $1.75-9.75$ & $\mathrm{PgR}>80 />4 \mathrm{yr}$ & 1.20 & 0.02 & 3.33 & $1.25-8.87$ \\
\hline $\mathrm{SPF} \leq 8$ & 0.13 & 0.73 & 1.13 & $0.56 \div 2.30$ & $S P F \leq 8$ & 0.20 & 0.55 & 1.22 & $0.65 \cdot 2.30$ \\
\hline Age $<50$ & 0.29 & 0.29 & 1.34 & $0.78-2.31$ & Age $<50$ & 0.22 & 0.43 & 1.24 & $0.72-2.14$ \\
\hline
\end{tabular}

$\mathrm{pl}_{2.3} />3$ yt

Ant multi $<5$ yr

$\mathrm{Pl}$.missing $<5 \mathrm{yr}$

$\operatorname{PgR}>80 /<5 \mathrm{yr}$

$\mathrm{ER} \leq 1.00$

SPF

$B$

RR

$\mathrm{Cl}$
: pathological stage $T_{2}$ and $T_{3}$, more than 3 years after diagnosis.

: aneuploid and multiploid tumours, less than 5 years after diagnosis.

: ploidy missing, less than 5 years after diagnosis.

: progesterone-receptor $>80 \mathrm{fmol} / \mathrm{mg}$ protein, less than 5 years from diagnosis.

aestrogen-receptor $\leq 100 \mathrm{fmol} / \mathrm{mg}$ protein.

S-phase fraction.

: parameter estimate.

risk ratio.

confidence interval.

\section{DISCUSSION}

In our series of 329 node-negative breast cancer patients aneuploidy but not S-phase fraction was an independent prognostic factor for overall survival after 96 months. Other independent prognosticators were $\mathrm{ER} \leq 100 \mathrm{fmol} / \mathrm{mg}$ protein, $\mathrm{ER}>400$ and $\mathrm{PgR} \leq 80$ (early years of follow-up). These factors in combination with $\mathrm{pT}$ also predicted a higher chance to develop distant metastases; the highest relative risk (RR 2.7) was observed in patients with aneuploidy. A combination of three factors (ER $\leq 100, E R>400$, aneuploidy and $\mathrm{pT}_{2-3}$ ) identified a cohort with a risk to develop recurrent disease, but the power of these observations is not sufficient to individualize therapy in breast cancer patients. A prognostic model, therefore, established in the way previously described using DNA flow cytometry for node-negative breast cancer patients ${ }^{37}$ should be used with caution.

In the past, a number of studies have addressed the question, whether data on ploidy and proliferation obtained with DNA FCM contribute to the prognosis of patients with axillary node-negative primary breast cance $r^{20-28,38-49}$. Results have been variable but in univariate analyses indications for a poorer prognosis for patients with aneuploid tumours were obtained in 15 of 19 studies. Our results confirm this relationship. Patients with aneuploid tumours have an almost four times higher chance to develop distant metastases at 3.5 years $(5 \%$ versus $19 \%, p=0.02)$. Similar differences were obtained in two of the largest other studies dealing with node-negative patients. Sigurdsson et al. ${ }^{37}$ found an almost twofold difference ( $12 \%$ versus $23 \%, \mathrm{p}=0.03$ ) in DFS at 4 years in 305 patients, 
whereas in the study of Clark et al. ${ }^{24}$, that included 345 patients the DFS at 5 years was somewhat more than twice as high in aneuploid tumours $(12 \%$ versus $26 \%, \mathrm{p}=0.02)$.

We did not find any statistically significant relation between outcome parameters and S phase fraction. Published data on this relationship show more disparity than the results of ploidy determination ${ }^{20,24,28,44,45}$. The problems inherent to a proper evaluation of the prognostic importance of SPF can best be discussed in relation to the results obtained in two other almost equally large studies in node-negative patients ${ }^{22,24}$. Clark et al. ${ }^{24}$ like us did not find a relationship between outcome parameters and SPF in an univariate analysis of his entire cohort. He did not include SPF in the multivariate analysis. Instead, SPF was found to have a significant prognostic impact in the group with diploid tumours. Given the good prognosis of this group, however, this conclusion was based on only 15 events, $10 / 97$ in the low and 5/15 in the high SPF subgroups. In our 137 diploid patients 14 events have occurred after 5 years with no differences between the low and high SPF subgroups. It is cleat, that with such low numbers of events conclusions on the role of SPF to predict recurrence in diploid patients, should be drawn with great caution.

Sigurdsson et al ${ }^{37}$ reported SPF to have a major prognostic impact in univariate and multivariate analyses and in diploid as well as aneuploid populations. One major difference between our and Clark's study is, that they were able to determine the SPF in $94 \%$ of their 305 specimens subjected to DNA FCM even without the application of software that is sometimes used to unravel overlapping populations with different degrees of ploidy. We found this impossible in $110 / 300(36 \%)$ of cases as did Clark et al. ${ }^{24}$ in $92 / 345(27 \%)$ of their histograms. We maintained these patients as missing cases in our analysis and found their prognosis favourable. This suggests, that many of these patients, if analyzed by Sigurdsson et al., would have been classified as to belong to the low SPF group and then have contributed substantially to the significantly better prognosis associated with this group. This is substantiated by the observed distribution of the patients over the less or more than $7 \%$ SPF groups. Whereas in both studies an identical $51 \%$ of cases had a SPF $\geq 7 \%$, Sigurdsson et al. found $42 \%$ to have $\leq 7 \%$ and the rest impossible to determine, whereas these figures were $21 \%$ and $29 \%$ respectively in our study.

Based on these data we feel that the results of studies on the relation between SPF and prognosis heavily depend on what has been done with histograms showing an overlapping aneuploid population of small size. If these patients are considered inevaluable, such as done by us and Clark et al. ${ }^{24}$, the prognostic impact of SPF may be absent or restricted to the group with a diploid tumour. If these patients are considered inevaluable but the so-called aneuploid fraction (relative proportion of aneuploid populations) is entered in the analysis, the latter will become a significant prognosticator and SPF again is negative. This thas been shown to be the case by Gnant et all. ${ }^{49}$. Finally, some investigators feel that a SPF can be determined in those cases, sometimes with the use of specially developed software ${ }^{50}$. In that case SPF will become a significant prognosticator. Whether this then really indicates an association between proliferation and prognosis or is mainly indicative of the presence of a low aneuploid fraction is at present unknown. Studies using the thymidine labelling index in node-negative breast 
cancer patients certainly indicate, that with this measure of DNA synthesis a subgroup with a high chance of relapse $(40 \%)$ in the first five years can be identified ${ }^{16.17}$. The final answer on the relative contribution of ploidy and proliferation to the prognosis of these patients awaits the evaluation of techniques that combine the specific measurements of proliferation-associated markers and chromosomal abnormalities ${ }^{5 \mathrm{l}}$.

Age below 51 was a prognostic factor for recurrence which was lost in multivariate analysis. In a large population-based study in Sweden, Adami et al. ${ }^{52}$ found the best prognosis in women between 45 and 49 years old with both younger and older patients having a poorer survival even after 5 years. In that study, however, patients were not stratified for stage. Sigurdsson et al. ${ }^{37}$ also found patients under 50 to have a higher rate of recurrent disease but this factor was lost in their multivariate analysis. Severall factors may explain this discrepancy, including the lower relative proportion of patients under 51 ( $24 \%$ versus $40 \%$ in our study), the restriction of the multivariate analysis to only the 250 patients with complete data and their observed correlation between age and SPF.

Taken together we found ploidy (diploid versus aneuploid/multiploid) and ER (cut-off points 100 and 400 ) to be the most important independent prognosticators in patients with node-negative $\mathrm{pT}_{1}-\mathrm{p} \mathrm{T}_{3}$ breast cancer. A main advantage of these 2 factors is, that they can be assessed with a minimum of subjectivity or modelling of data. Multivariate analysis indicates ploidy and steroid-receptor content as independent prognosticators. Our data indicate, however, that with the currently available methods we are not able to develop models that predict prognosis in a consistent and clinically reliable way. 


\section{REFERENCES}

1 Harris JR, Hellman S, Canellos GP, Fisher B. Cancer of the breast. In: DeVita VT Jr, Hellman S, Rosenberg SA, eds. Cancer: Principles and Practice of Oncology, 2nd ed. vol.2. Philadelphia: JB Lippincott 1985: 1119-1177.

2 Seidman $\mathrm{H}$, Gelb SK, Silverberg $\mathrm{E}$ et al. Survival experience in the breast cancer detection demonstration project. CA $1987 ; 37: 258-290$.

3 Haagensen CD. Treatment of curable carcinoma of the breast.

Int J Radiat Oncol Biol Phys 1977; 2: 975-980.

4 Fisher B, Redmond C, Dimitrov NV et al. A randomized clinical trial evaluating sequential methotrexate and fluorouracil in the treatment of patients with node-negative breast cancer who have oestrogen-receptor-negative tumours.

N Engl J Med 1989; 320: 473-478.

5 Fisher $B$, Constantino $J$, Redmond $C$ et al. A randomized clinical trial evaluating tamoxifen in the treatment of patients with node-negative breast cancer who have oestrogen-receptor-positive tumours. N Engl J Med 1989; 320: 479-484.

6 Mansour EG, Gray R, Shatila AH et al. Efficacy of adjuvant chemorherapy in high-risk node-negative breast cancer: an intergroup study. N Engl J Med 1989; 320: 485-490.

7 The Ludwig Breast Cancer Study Group. Prolonged disease-free survival after one course of perioperative adjuvant chemotherapy for node-negative breast cancer.

N Engl J Med 1989; 320: 491-496.

8 Early Breast Cancer Trialists' Collaborative Group. Systemic treatment of earjy breast cancer by hormonal, cytotoxic, or immune therapy.

The Lancet 1992; 339: 1-15 and 71-85.

9 Rutgvist LE, Cedremark $B$, Glas $U$ et al. Contralateral primary tumours in breast cancer patients in a randomized trial of adjuvant tamoxifen therapy.

J Natl Cancer Inst 1991; 83: 1299-1306.

10 Rosen PP, Groshen S, Saigo PE et al. A long-term follow-up study of survival in stage I $\left(\mathrm{T}_{1} \mathrm{~N}_{0} \mathrm{M}_{0}\right)$ and stage II $\left(\mathrm{T}_{1} \mathrm{~N}_{1} \mathrm{M}_{0}\right)$ breast carcinoma. J Clin Oncol 1989; 7: 355-366.

11 Ariel IM. Results of treatment in 1178 patients with breast cancer by radical mastectomy and postoperative irradiation where metastases to axillary lymph nodes occurred.

J Surg Oncol 1979; 12: 137-153.

12 Valagussa $P$, Bonadonna $G$, Veronesi $U$. Patterns of relapse and survival following radical mastectomy: analysis of 716 consecutive patients. Cancer 1987; $41: 1170-1178$.

13 Arriagada R, Rutqvist LE, Skoog L et al. Prognostic factors and natural history in lymph node-negative breast cancer patients. Breast Cancer Res Treatm 1992; 21: 101-109.

14 Lipponen $\mathrm{P}$, Aaltomaa $\mathrm{S}$, Eskelinen $\mathrm{M}$ et al. The changing importance of prognostic factors in breast cancer during long term follow-up. Int J Cancer 1992; 51: 698-702.

15 Gilchrist RW, Kalish L, Gould VE et al. Interobserver reproducibility of histopathologicall features in stage II breast cancer: viewpoints.

Breast Cancer Res Treat 1985; 5: 3-10.

16 Silvestrini $R$, Daidone $\mathrm{MG}$ Gasporini $\mathrm{G}$. Cell kinetics as a prognostic marker in nodenegative breast cancer. Lancet 1985; 56: 1982-1987.

17 Meyer JS, Friedman E, McCreate M, Baur WC. Prediction of early course of breast cancer by thymidine labelling. Cancer 1983; 51 : 1879-1886.

18 Barlogie $B$, Raber MN, Schumann $J$ et al. Flow cytometry in clinical cancer research. Cancer Res $1983 ; 43: 3982-3997$.

19 McDivitt RW, Stone KR, Meyer IS. A method for dissociation of viable human breast cancer cells that produces flow cytometric information similar to that obtained by thymidine labelling. Cancer Res 1984; 44: 2628-2644. 
20 Kallioniemi O-P, Hietanen $T$, Matilla $J$ et al. Aneuploid DNA content and high S-phase fraction of tumour cells are related to poor prognosis in patients with primary breast cancer. Eur I Cancer Clin Oncol 1987; 23: 277-282.

21. Coulson PB, Thornthwaite JT, Woolley TW et al. Prognostic indicators including DNA histogram type, receptor content, and staging related to human breast cancer patient survival. Cancer Res $1984 ; 44: 4187-4196$.

22 Muss HB, Kute TE, Case LD et al. The relation of flow cytometry to clinical and biologic characteristics in women with node-negative primary breast cancer.

Cancer 1989; 64: 1894-1900.

23 Lewis WE. Prognostic significance of flow cytometric DNA analysis in node-negative breast cancer patients. Cancer 1990; 65: 2315-2320.

24 Clark GM, Dressler LG, Owens MA et al. Prediction of relapse or survival in patients with node-negative breast cancer by DNA flow cytometry.

N Engl J Med 1989; 320: 627-633.

25 Beerman $H$, Kluin PhM, Hermans $J$ et al. Prognostic significance of DNA ploidy in a series of 690 primary breast cancer patients. Int J Cancer 1990; 45: 34-39.

26. O'Reilly SM, Camplejohn RS, Barnes DM et al. Node-negative breast cancer: prognostic subgroups defined by tumour size and flow cytometry. J Clin Oncol 1990; 8: 2040-2046.

27 Kallioniemi O-P, Blanco $G$, Alavaikko $M$ et al. Tumour DNA ploidy as an independent prognostic factor in breast cancer. Br J Cancer 1987; 56: 637-642.

28 Toikkanen $S$, Joensuu $\mathrm{H}$, Klemi PJ. Nuclear DNA content as prognostic factor in $\mathrm{T}_{1-2} \mathrm{~N}_{0}$ breast cancer. Am J Clin Pathol 1990; 93: 471-479.

29 Staging for carcinoma of the breast. In: Beahrs O, Henson D, Hutter R, Myers M, eds. Manual for staging of cancer, 3rd ed. Philadelphia, JB Lippincott, 1988: 145-150.

30 Bloom HJG, Richardson WW. Histologic grading and prognosis in breast cancer.

Br J Cancer 1957; 11: 359-377.

31 Scatchard $G$. The attraction of proteins for small molecules and ions.

Ann NY Acad Sci 1949; 51: 660-672.

32. Lowry OH, Rosebrough NJ, Farr AL and Randall RJ. Protein measurement with the folin phenol reagent. J Biol Chem 1951; 193: 265-275.

33 Hedley DW. flow cytometry using paraffin-embedded tissue: five years on. Cytometry 1989; 10: 229-241.

34 Schutte B, Reynders MMJ, Bosman FTG et al Flow cytometric determination of DNA ploidy level in isolated nuclei from paraffin embedded tissue. Cytometry 1986; 6: 26-30.

35 Vindellov LL, Christensen U, Nissen NI. A detergent trypsin method for the preparation of nuclei for flow cytometric DNA analysis. Cytometry 1984: 5: 408-419.

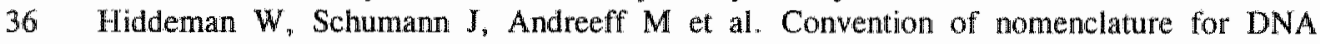
cytometry. Cytometry 1984; $5: 445-446$.

37 Sigurdsson $\mathrm{H}$, Baldetorp $\mathrm{B}$, Borg $\AA$ et al. Indicators of prognosis in node-negative breast cancer. N Engl J Med 1990; 322: 1045-1053.

38 Yan J, Hennessy $C$, Corbett IP et al. Node-negative breast cancer: the prognostic value of DNA ploidy for long term survival. Br I Surg 1991; 78: 844-848.

39 Kallioniemi O-P, Blanco G, Alawaikko $M$ et al. Improving the prognostic value of DNA flow cytometry by combining DNA index and S-phase fraction: a proposed classification of DNA histograms in breast cancer. Cancer 1988; 62:2183-2190.

40 Joensuw $H$, Toikkanen S, Klemi PJ. DNA index and S-phase fraction and their combination as prognostic factors in operable ductal breast carcinoma.

Cancer 1990; 64: 1074-1081. 
41. Amerlow C, Emdin SO, Roos $G$ et al. Static and flow cytometric DNA analysis compared to histologic prognostic factors in a cohort of stage $T_{2}$ breast cancer.

Eur J Surg Oncol 1990; 16 (3): 200-208.

42 Sunderland MC, McGuire WL. Prognostic indicators in invasive breast cancer.

Surg Clin North Am 1990; 70 (5): 989-1004.

43 Yan $J$, Hennessy C, Corbett JP. Node-negative breast cancer: the prognostic value of DNA ploidy for long-term surviwal: a comment. Br J Surg 1991; 78 (7): 844-848.

44 Wong WW, Vujayakumar $\mathrm{S}$, Weichselbaum RR. Prognostic indicators in node-negative carly stage breast cancer. Am J Med 1992; 92 (5): 539-548.

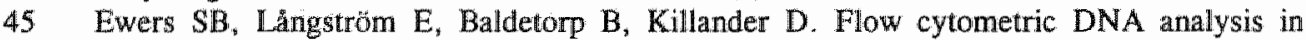
primary breast carcinomas and clinicopathological correlations.

Cytometry 1984; 5: 408-419.

46 Cornelisse $\mathrm{CJ}$, van de Velde CJH, Caspers RJC el al. DNA ploidy and survival in breast cancer patients. Cytometry 1987; 8: 225-234.

47 Keyhani-Rofagha S, O'Toole RV, Farrar WB. Is DNA ploidy an independent prognostic indicator in infiltrative node-negative breast adenocarcinoma?

Cancer 1990; 65: 1577-1582.

48 Fisher $B$, Gunduz $N$, Constantino $J$ et al. DNA flow cytometric analysis of primary operable breast cancer: relation of ploidy and $\$$-phase fraction to outcome of patients in NSABP B-04. Cancer 1991; 68: 1465-1475.

49 Gnant MFX, Blijham GH, Reiner A et al. Aneuploidy fraction but not DNA index is important for the prognosis of patients with stage I and II breast cancer - 10 year results. Annals of Oncology 1993; 4: 643-650.

50 Dressler LG, Seamer L, Owens MA et al. Evaluation of a modeling system for S-phase estimation in breast cancer by flow cytometry. Cancer Res 1987; 47: 5294-5302.

51 Dutrillaux B, Gerbault-Seureau M, Zafrani B. Characterization of chromosomal anomalies in human breast cancer. A comparison of 30 paradiploid cases with few chromosome changes. Cancer Genet Cytogenet 1990; 49: 203-217.

52 Adami HO, Malker $\mathrm{B}$, Holmberg $\mathrm{L}$ et al. The relation between survival and age at diagnosis in breast cancer. N Engl J Med 1986; 315: 559-563. 


\section{THE PROGNOSTIC AND PREDICTIVE VALUE OF FLOW CYTOMETRY IN NODE-POSITIVE BREAST CANCER PATIENTS}

PSGJ Hupperets, L Volovics, B Schutte, JAMJ Wils, LJ Schouten, HC Schouten, HFP Hillen and GH Blijham, on behalf of the Breast Cancer Study Group from the Comprehensive Cancer Center Limburg 


\section{THE PROGNOSTIC AND PREDICTIVE VALUE OF FLOW CYTOMETRY IN NODE-POSITIVE BREAST CANCER PATIENTS}

\section{ABSTRACT}

\section{Introduction}

DNA flow cytometry derived parameters (ploidy and S-phase fraction (SPF)) may provide important information on the prognosis for relapse and survival of node-positive breast cancer patients. Results have been equivocal, however, which may partly be due to inhomogeneity of studied populations and short follow-up.

Aim

We investigated the prognostic significance of ploidy and SPF in a homogeneously treated axillary node-positive breast cancer population $(n=320)$, postoperatively treated with chemotherapy with or without medroxyprogesterone acetate. The median follow-up time is 7 years.

\section{Results}

Age, receptor status and most importantly axillary node status were the only independent prognostic variables in the multivariate analysis. Aneuploidy was a factor predicting poor prognosis in the univariate analysis but, as SPF, was not independently important. However, in the multivariate analysis, patients with aneuploid breast cancers have a significant higher risk for distant metastases (RR 3.59) and tumour related death (RR 2.56) when treated with chemo-hormonal adjuvant treatment if compared to patients with diploid tumours. This was due to the very favourable prognosis of this latter group, also if compared to patients not treated with MPA.

\section{Conclusion}

Ploidy and SPF are not independent prognostic factors in this large study node-positive breast cancer patients and should not routinely be analyzed in this population. Ploidy, however, may predict whether a patient would benefit from the addition of endocrine to cytotoxic adjuwant treatment.

\section{INTRODUCTION}

Ideally, the strategy for the treatment of breast cancer depends on information on the biological behaviour of the individual tumours. A number of potential prognostic factors have been identified and examined for their ability to predict for outcome of this disease. The most important prognostic indicator is the presence or absence of breast cancer cells in the axillary lymph nodes ${ }^{1}$. Also, tumour size $^{2.3}$, histological and nuclear grading and steroid hormone receptor status ${ }^{47}$ are important prognostic factors which may predict for the clinical outcome of the individual patient. 
DNA flow cytometry has been used to predict the clinicall outcome of patients with breast cancer. Several studies have been published within the last years, comparing ploidy and S-phase fraction (SPF) with important clinical parameters in node-positive breast cancer patients. The question whether these data provide independent prognostic information on survival or relapse, was answered with conflicting results ${ }^{8-17}$, mainly because of relatively small numbers of patients or short follow-up and heterogeneous patient populations.

The aim of this study was to investigate in a large cohort of uniformly staged and treatted patients with a median follow-up of 7 years, the prognostic significance of DNA-ploidy and SPF for the clinical outcome in axillary node-positive breast cancer patients. These patients were part of a clinical trial which included locoregional treatment followed by adjuvant therapy. Univariate and multivariate analysis were performed to identify groups. of patients with high and low risks for relapse or death from breast cancer.

\section{PATIENTS AND METHODS}

\section{Patients}

Three hundred and twenty patients with axillary node-positive breast cancer $\left(\mathrm{p} T \mathrm{~T}_{1-3}, \mathrm{~N}_{1}\right.$, $\mathrm{M}_{0}$ ) entered a prospective randomized clinical trial between June 1982 and July 1987 , analysing the value of adjuvant hormonal treatment in addition to standard chemotherapy. Excluded were patients over 70 years of age, patients with previous malignancies except non-melanoma skin cancer and optimally treated stage la cervical cancer. Patients were registered and randomized preoperatively and stratified by $\mathrm{T}_{-}, \mathrm{N}-$, menopausal and steroid-receptor status. Surgical treatment consisted either of conservative breast surgery with axillary node dissection $(n=45)$, modified radical mastectomy with axillary node dissection $(n=268)$ or radical mastectomy $(n=2)$. From 5 patients the surgical procedure could not be recovered from the records. Postoperative locoregional irradiation was given in patients with centrally or medially localized breast cancer (parasternal radiation field) $(n=46)$ and in patients with microscopically irradical operation (chest wall radiation) $(\mathrm{n}=18)$. All 45 patients who underwent conservative breast surgery had complete radiation of the breast with a boost at the lumpectomy site. Patients with tumour containing lymph nodes were treated with adjuvant therapy according to the allocated treatment of the trial (see further). The clinical characteristics of the patients are shown in table 1 . The median follow-up time of the 320 patients was 84 months, as of their last recorded follow-up evaluation; 171 patients were alive $(53.4 \%)$ and 143 patients were free of recurrence $(44.7 \%)$.

In $91(28.4 \%)$ of the patients a pathologically $\mathrm{T}_{1}(\mathrm{pT})$ tumour was diagnosed in 199 $(62.2 \%)$ of the women the tumour was classified as $\mathrm{pT}_{2}$ whereas in $9.4 \%$ of the patients a $\mathrm{pI}$, tumour was diagnosed.

The distribution of the number of involved nodes in these patients was as follows: 183 women (57.2\%) had 1-3 axillary nodes containing breast cancer, 108 women (33.8\%) 4-9 tumour containing nodes, and 29 women $(9.0 \%) \geq 10$ pathological nodes. 
Table I Patient characteristics of node-positive breast cancer patients.

\begin{tabular}{|c|c|c|}
\hline Parameter & Number of patients & Percentage \\
\hline \multicolumn{3}{|l|}{ Size } \\
\hline $\mathrm{pT}_{\mathrm{s}}$ & 91 & 28.4 \\
\hline $\mathrm{pT} \mathrm{T}_{2 n 3}$ & 229 & 71.6 \\
\hline \multicolumn{3}{|l|}{ Ploidy } \\
\hline diploid & 89 & 27.8 \\
\hline aneupl/multipl & 203 & 63.4 \\
\hline "no data" & 28 & 8.8 \\
\hline \multicolumn{3}{|l|}{ Histology } \\
\hline infiltrating ductal ca. & 282 & 88.1 \\
\hline infiltrating lobular & 17 & 5.1 \\
\hline miscellaneous & 21 & 7.6 \\
\hline \multicolumn{3}{|l|}{ Number of positive nodes } \\
\hline $1-3$ & 183 & 57.2 \\
\hline $4-9$ & 108 & 33.8 \\
\hline$>9$ & 29 & 9.0 \\
\hline \multicolumn{3}{|l|}{ S-phase fraction } \\
\hline$\leq 8 \%$ & 88 & 27.5 \\
\hline$>8 \%$ & 70 & 21.9 \\
\hline "no data" & 162 & 50.6 \\
\hline \multicolumn{3}{|l|}{ Progesterone-receptor } \\
\hline$\leq 60$ & 169 & 52.8 \\
\hline$>60$ & 80 & 25.0 \\
\hline missing values & 71 & 22.2 \\
\hline \multicolumn{3}{|l|}{ Oestrogen-receptor } \\
\hline$\leq 10$ & 119 & 37.2 \\
\hline$>10$ & 186 & 58.1 \\
\hline missing values & 15 & 5.7 \\
\hline \multicolumn{3}{|l|}{ Age distributions } \\
\hline$\leq 50$ years & 134 & 41.9 \\
\hline$>50$ years & 186 & 58.1 \\
\hline
\end{tabular}

From $249(77.8 \%)$ women the progesterone-receptor $(\mathrm{PgR})$ of the primary tumour was known whereas in $305(95.3 \%$ ) of the cases the oestrogen-receptor (ER) could be calculated. This discrepancy in numbers is caused by later availability of $\mathrm{PgR}$ determination.

Adjuvant treatment of the node-positive patients and follow-up

Patients were randomly allocated into two groups: A. chemotherapy consisting of cyclophosphamide $500 \mathrm{mg} / \mathrm{m}^{2}$, doxorubicin $40 \mathrm{mg} / \mathrm{m}^{2}$, and 5 -fluorouracil $500 \mathrm{mg} / \mathrm{m}^{2}$ on day 1 q 4 weeks for a total of six cycles of chemotherapy; B: the same chemotherapy schedule as in A in combination with medroxyprogesterone acetate (MPA) daily $500 \mathrm{mg}$ intramuscularly (i.m.) for 28 days, followed by $500 \mathrm{mg}$ i.m. twice a week for 5 months. Follow-up included a history and physical examinations, blood counts, glutamyl transferase (gamma-GTP), lactate dehydrogenase (LDH), calcium, erythrocyte 
sedimentation rate and carcino-embryogenic antigen (CEA). Chest radiographs and mammography were performed annually.

\section{Histological examinations and flow cytometry}

The histologic grade was determined by the method of Bloom and Richardson ${ }^{18}$. Destrogen- and progesterone-receptor contents were assayed with the dextran-coated charcoal method, Scatchard analysis and calculation according to the method of Lowry ${ }^{19,20}$ 。

Flow cytometric determination of DNA levels was performed in nuclei isolated from paraffin-embedded tissue ${ }^{9.21}$. Fifty $\mu \mathrm{m}$ sections were cut from formalin fixed paraffin embedded tissue blocks containing a representative sample of the primary tumour. Five $\mu \mathrm{m}$ sections were cut for histological control to make sure that the $50 \mu \mathrm{m}$ sections contained tumour. DNA content was measured by the method of Vindelov $\mathrm{v}^{22}$. Tumours with a single G1 peak were considered to be diploid, whereas evidence of an additional G1 peak indicated aneuploidy. DNA index (DI) was calculated as the ratio of aneuploid to diploid G1/0 peak channel. Histograms with coefficients of variation (CV) less than $8 \%$ were considered of good quality. Histograms with $\mathrm{CV}>8 \%$ were classified as not interpretable. The proliferative activity (SPF) was planimetrically calculated by counting the number of cells between the inclination points of the descending G1 peak and the ascending $\mathrm{G} 2 / \mathrm{M}$ peak ${ }^{9,23}$. The SPF calculations were performed by two individuals, independently from each other. In case of discrepancy in calculations the results were middled. In cases of less than $30 \%$ admixture of diploid cells, the percentage of aneuploid S-phase cells was calculated without corrections for the presence of diploid Sand $\mathrm{G} 2 / \mathrm{M}$ phase cells. In case of more than $30 \%$ admixture diploid cells in overlapping of diploid and hyperdiploid histograms the percentage of S-phase cells was not calculated. When ploidy status could not be determined because of poor quality of the sample, these histograms were considered uninterpretable.

After descriptive analysis the cutoff levels for the proportion of S-phase cells were set at $\leq 8 \%$, and $>8 \%$ in order to define two groups, with low and high SPF respectively.

\section{Statistical analysis}

To investigate the prognostic significance of the clinical parameters included in the study, Kaplan-Meier estimates of survival curves, logrank tests for comparing two or more groups and the Cox proportional-hazards regression model were used. All analyses were done using the statistical packages SAS (SAS Institute Inc., Cary, NC, USA) and S-PLUS (Statistical Sciences Europe, Oxford, UK).

First routine univariate analyses were done to compare survival curves using quartile, quintile and accepted clinical cutoff points for the prognostic variables with respect to the end points "overall survival' (OS) and 'distant metastasis free survival" (DMFS).

Secondly all prognostic variables were included in a Cox regression analysis with respect to these endpoints. For every variable the assumptions of the Cox regression model, i.e. proportional hazards and log-linearity of effect, were checked.

The proportional hazards assumption was checked through different graphical plots and using tests based on Schoenfeld residuals. Log-linearity of effects was checked through generalized additive modelling and smoothing of partial residual plots.

Influence diagnostics and residual plots were also used to check for undue dependence of 
the 'definite' models on the influence of a subset of patients.

To examine a possible difference in prognostic value of the clinical parameters between the MPA-positive and the MPA-negative treatment groups, all interaction terms between MPA and the clinical parameters were included in the model. Backward elimination was used to retain only those interaction terms suggestive of systematic prognostic differences between MPA treated and non-MPA treated patients.

With regard to both OS and DMFS there was a definite suggestion of non-proportionality for the effect of oestrogen-receptor content and of a possible non-linearity of effect for age, S-phase percentage, progesterone-receptor content, oestrogen-receptor content and number of positive axillary nodes. The non-linearities suggested by the analyses could in all cases adequately be simplified by taking cut-off points: oestrogen-receptor content at $10 \mathrm{fmol} / \mathrm{mg}$ protein, progesterone-receptor content at $60 \mathrm{fmol} / \mathrm{mg}$ protein, number of positive axillary nodes at 3 and 9 , age at 50 and S-phase at $8 \%$. The non-proportionality of oestrogen-receptor content was resolved by including a time dependent effect; the difference in effect between ER-content $\leq 10$ and ER $>10$ seemed to diminish between about 4 to 5 years after diagnoses for DMFS and at approximately 4 to 6 years after diagnoses for OS.

The p-values derived from multivariate analyses are the end result of data exploration and should not be interpreted as direct tests of a hypothesis of no prognostic effect. The Kaplan-Meier curves and logrank tests presented for the prognostic variables are based on the cut-off points used in the multivariate analyses.

Given the for this analyses relatively small number of patients and events we did not attempt split-sample validation or correction for overfitting.

Correlation of covariates was calculated using Kendall's rank correlation rau. Age and ploidy were correlated: older women ( $>50$ years) had a higher percentage aneuploid tumours compared to women $\leq 50$ years $(r=0.279, p=0.003)$. $\mathbb{R R}$ and $\mathrm{PgR}$ were correlated with aneuploidy ( $\mathrm{r}$-values respectively 0.241 and 0.232 , p-values respectively 0.01 and 0.02 ).

No correlation was found between SPF and number of axillary nodes or between SPF and other combinations of variables.

\section{RESULTS}

From the 320 patients in $12(3.7 \%)$ no tumour specimen was available and in $16(5 \%)$ the histogram could not be interpreted. The main characteristics of these cases did not differ significantly from those patients with interpretable histograms, nor was the RFS or OS different for these 28 patients. The following analyses were related to all 320 patients with axillary node-positive breast cancer. Of the analyzed patients $27.8 \%$ were diploid and $63.4 \%$ aneuploid or multiploid. In $158(49.4 \%)$ of these patients it was possible to determine the SPF. Of all tumour specimens $27.5 \%$ had an SPF $\leq 8 \%, 21.9 \%$ had an $\mathrm{SPF}>8 \%$, and $50.6 \%$ was not analyzable. 
Univariate analysis

Univariate analysis performed with all the covariates listed in table I revealed that ploidy status was able to distinguish between patient groups at high and low risk for overall survival (OS) $(p=0.03)$ and distant metastases free survival (DMFS) $(p=0.04)$ (figure 1, 2).

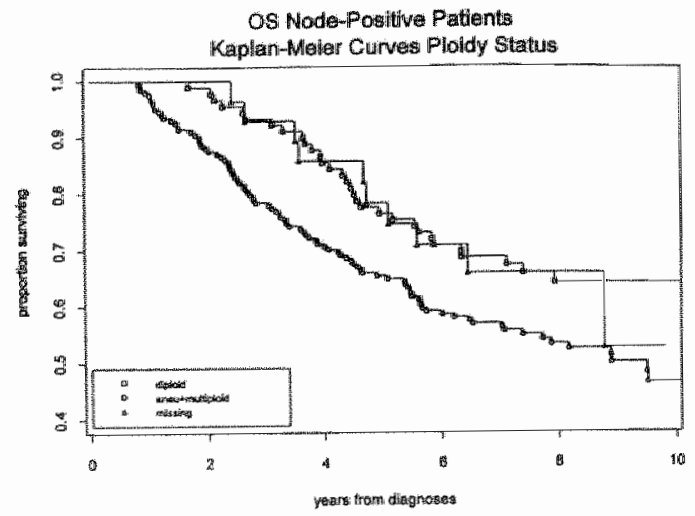

Figure 1 Kaplan-Meier overall survival (OS) curves in node-positive breast cancer patients. Diploid breast cancer patients have a lower risk for dying $(\mathrm{p}=0.03)$.

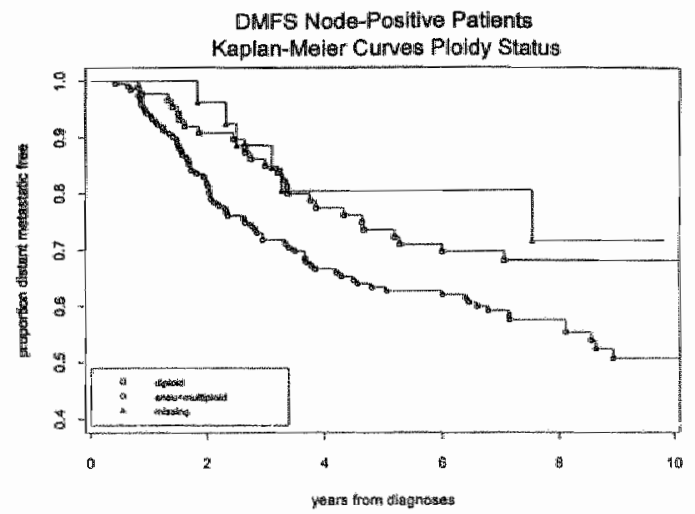

Figure 2 Kaplan-Meier distant metastases free survival (DMFS) curves in node-positive breast cancer patients. Diploid patients have a lower risk for distant metastases $(p=0.04)$.

SPF was not able to distinguish between a high and a low risk group. Kaplan-Meier curves for OS and DMFS showed a statistically not significant higher risk for SPF stratum $\geq 8 \%$. Other significant variables in univariate analyses for DMFS and OS were pT, PgR status (cut-off point 60), age and number of tumour containing axillary nodes. 
Table I Univariate analysis of prognostic variables in 320 node-positive breast cancer patients $\left(\mathrm{pT}_{1,3}\right)$ with a median follow-up of 7 years.

\begin{tabular}{|c|c|c|c|c|c|c|c|}
\hline \multirow[t]{2}{*}{ Parameter } & \multirow[t]{2}{*}{ No pts. } & \multicolumn{2}{|c|}{$\begin{array}{l}\text { DMFS } \\
\text { No events }\end{array}$} & \multirow[t]{2}{*}{${ }_{\mathrm{p} \text {-value }}^{\text {OS }}$} & \multicolumn{2}{|c|}{ No events } & \multirow[t]{2}{*}{ p-Walue } \\
\hline & & obs & $\exp$ & & obs & $\exp$ & \\
\hline \multicolumn{8}{|l|}{ Ploidy } \\
\hline diploid & 89 & 28 & 36.2 & & 31 & 43.4 & \\
\hline aneupl\&multipl & 203 & 77 & 64.3 & 0.04 & 95 & 80.1 & 0.03 \\
\hline "no data" & 28 & 6 & 10.5 & & 10 & 12.6 & \\
\hline \multicolumn{8}{|l|}{ Size } \\
\hline $\mathrm{pT}_{\mathbb{\sharp}}$ & 91 & 23 & 36.4 & & 28 & 43,0 & \\
\hline $\mathrm{pT}_{2-3}$ & 229 & 88 & 74.6 & 0.007 & 108 & 92.9 & 0.006 \\
\hline \multicolumn{8}{|l|}{ ER status } \\
\hline$\leq 10$ & 119 & 32 & 38.5 & & 53 & 45.61 & \\
\hline$>10$ & 186 & 72 & 66.9 & 0.40 & 78 & 53.6 & 0.36 \\
\hline mïssing & $\mathbb{1 5}$ & 7 & 5.5 & & 5 & 6.8 & \\
\hline \multicolumn{8}{|l|}{ PgR status } \\
\hline$\leq 60$ & 169 & 65 & 51.1 & & 85 & 65.2 & \\
\hline$>60$ & 80 & 19 & 32.2 & 0.01 & 23 & 38.3 & 0.002 \\
\hline missing & 71 & 27 & 27.7 & & 28 & 32.5 & \\
\hline \multicolumn{8}{|l|}{ Age } \\
\hline$\leq 50$ & 134 & 33 & 51.1 & & 42 & 61.1 & \\
\hline$>50$ & 186 & 78 & 59.9 & 0.001 & 94 & 74.9 & 0.001 \\
\hline \multicolumn{8}{|l|}{ SPF } \\
\hline$\leq 8$ & 88 & 31 & 34.2 & & 34 & 41.7 & \\
\hline$>8$ & 70 & 25 & 21.7 & 0.67 & 30 & 27.7 & 0.36 \\
\hline "no data" & 162 & 55 & 55.03 & & 72 & 66.6 & \\
\hline \multicolumn{8}{|c|}{ Number axillary nodes } \\
\hline $1-3$ & 183 & 45 & 73.04 & & 50 & 87.3 & \\
\hline 4.9 & 108 & 49 & 32.76 & $<0.001$ & 61 & 41.7 & $<0.001$ \\
\hline$\geq 10$ & 29 & 17 & 5.2 & & 25 & 7.08 & \\
\hline
\end{tabular}

\section{Multivariate analysis}

Cox proportional hazards regression with respect to DMFS revealed that age, PgR, ER and the number of tumour containing axillary nodes were independent prognostic factors (table II). Ploidy was not an independent prognostic factor. However, if MPA treatment was also taken into account it appeared that MPA-positive aneuploid and multiploid patients had a hazard ratio (RR) of 3.59 (95\% CI 0.74-17.29) for DMFS and of 2.56 (95\% CI 1.24-5.31) for OS as compared to diploid patients $(\mathrm{p}=0.004$ and 0.02 respectively) (table II). For MPA-negative patients hazard ratio's close to $1(0.81$ for DMFS and 1.01 for OS) were observed. With this finding from the multivariate analysis in mind, Kaplan-Meier curves were constructed showing a significant lower risk of relapse and death for diploid, MPA-treated patients as compared to the three other groups (figure 3). Apparently diploidy is a positive predictor for a MPA treatment effect. 
Table II Multivariate analysis (Cox proportional hazards regression) of prognostic covariates of survival in 320 node-positive $\left(\mathrm{pT}_{1-3}\right)$ breast cancer patients with a median follow-up of 7 years.

\begin{tabular}{lccccccc}
\hline & \multicolumn{3}{c}{ DMFS } & & \multicolumn{3}{c}{ OS } \\
Parameter & $B$ & p-walue & RR & B & p-value & RR \\
\hline MPA & -0.82 & 0.19 & 0.440 & -0.69 & 0.05 & 0.502 \\
pT $_{2-3}$ & -0.25 & 0.43 & 0.778 & 0.12 & 0.59 & 1.128 \\
an +multipl & -0.22 & 0.54 & 0.805 & 0.01 & 0.96 & 1.015 \\
ER $\leq 10<5$ yr & 0.57 & 0.03 & 1.776 & 1.05 & 0.0001 & 2.850 \\
PgR $\leq 60$ & 0.62 & 0.02 & 1.857 & 0.50 & 0.04 & 1.638 \\
Age $>50$ & 1.04 & 0.002 & 2.855 & 0.45 & 0.01 & 1.572 \\
Naxill.nodes & & & & & & \\
$\quad 4-9$ & 0.64 & 0.003 & 1.910 & 0.77 & 0.0002 & 2.163 \\
$\quad \geq 10$ & 1.95 & 0.0001 & 7.005 & 2.01 & 0.0001 & 7.472 \\
SPF $>8$ & 0.38 & 0.33 & 1.462 & 0.28 & 0.36 & 1.320 \\
MPA an multi & 1.49 & 0.004 & 3.591 & 0.93 & 0.02 & 2.555 \\
MPA age $>50$ & -1.03 & 0.02 & 0.357 & -0.63 & 0.11 & 0.535 \\
MPA SPF $>8$ & -1.27 & 0.04 & 0.408 & -0.99 & 0.03 & 0.493 \\
MPA pT & 0.97 & 0.04 & 2.646 & & & \\
\hline
\end{tabular}

$\mathrm{pT}_{2,3} \quad$ : pathological stage $\mathrm{T}_{2}$ and $\mathrm{T}_{3}$

MPA an +multi : patients treated with medroxyprogesterone acetate, with aneuploid and multiploid tumours.

$\mathrm{ER} \leq 10<5 \mathrm{yr}$ : oestrogen-receptor $\leq 20$ fmol/mg protein; follow-up less than 5 years after diagnosis

$\mathrm{PgR}_{\mathrm{g}} \leq 60 \quad$ : progesterone-receptor $\leq 60 \mathrm{fmol} / \mathrm{mg}$ protein

$\mathrm{N}$ axill. nodes : number of tumour containing axillary nodes

SPF : S-phase fraction

B : parameter estimate

RR : risk ratio

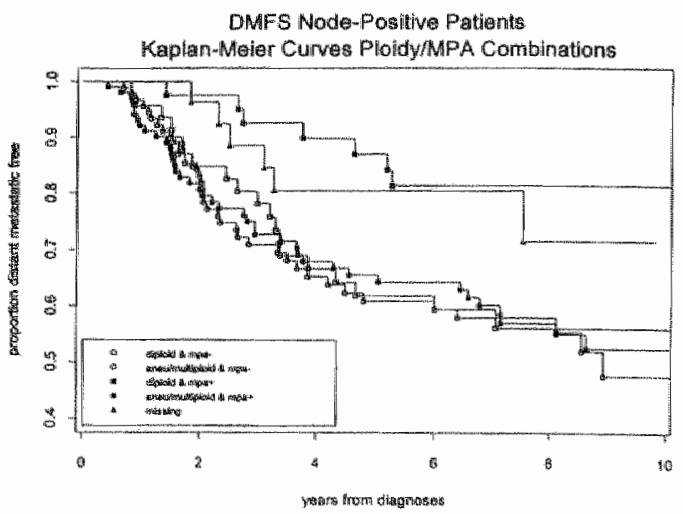

Figure 3 Kaplan-Meier DMFS curves in node-positive breast cancer patients combining ploidy and MPA treatment. Diploid patients treated with MPA have a lower risk for distant metastases. 
SPF was not a significant prognostic factor in the multivariate analysis. Treatmentrelated analyses suggested some predictive effect for the treatment with MPA. The RR of patients with MPA-treatment and SPF $\geq 8 \%$ was $0.41(95 \% \mathrm{CI} 0.008-2.1)$ for DMFS and $0.49(95 \% \mathrm{CI} 0.19-1.27)$ for OS compared to patients with SPF $<8 \%$ (table II). Without MPA treatment the RR's were slightly over 1 (not shown). Kaplan-Meier curves suggest that MPA improves the prognosis of the SPF $\geq 8 \%$ group, which in itself is doing rather poorly (figure 4). Interpretation of these data is hampered by the relatively large group of patients without SPF data.

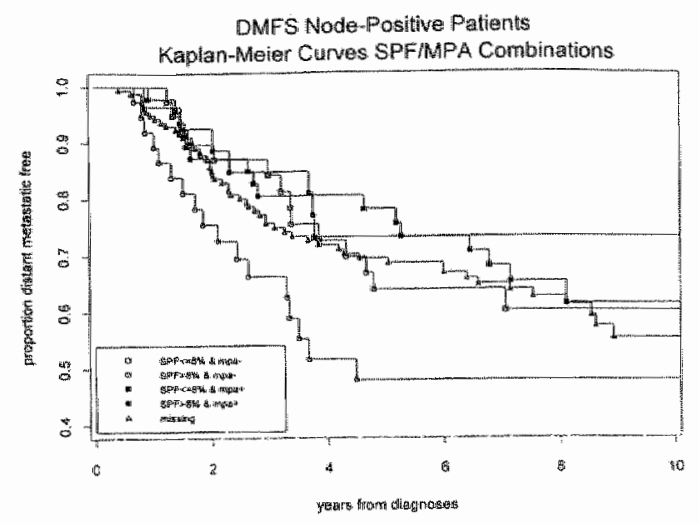

Figure 4 Kaplan-Meier DMFS curves in node-positive breast cancer patients combining SPF and MPA treatment. Patients with SPF $>8 \%$ treated with MPA have a lower risk for distant metastases

\section{DISCUSSION}

The main result of our study is that in node-positive breast cancer patients treated with adjuvant chemotherapy, FCM derived parameters have no independent prognostic effect after correction of stage, age and receptor status but rather may be predictive factors for the effects of additive high-dose treatment with a progestagen. This important result may be the start for defining new roles for aneuploidy and cell kinetics and also may in part explain conflicting results from earlier studies, that used a variety of cytotoxic and hormonal adjuvant treatments.

In the literature diploidy of breast tumours has been reported to be a favourable prognostic indicator using univariate analysis ${ }^{8,10-12,24-30}$. However, some investigators did not detect a significant correlation between ploidy levels and prognosis ${ }^{13,31,32}$ whereas in other studies this relationship was limited to node-positive patients.10.28 or has lost significance in multivariate analysis ${ }^{10,33,34}$. Our study shows that diploid patients treated with chemotherapy combined with MPA have a significant lower risk compared to nondiploid patients treated with the same adjuvant therapy and compared to the diploid 
group of patients treated with adjuvant chemotherapy only. This suggests a predictive rather than a prognostic role of ploidy for breast cancer patients who are being treated with combinations of cytotoxic and endocrine treatment.

One explanation of the finding, that diploidy predicts a positive adjuvant effect of MPA could be, that diploidy serves as a surrogate marker for ER or PgR-positivity. Indeed we observed a correlation between ER and PgR status on one hand and ploidy on the other hand. This has also been reported in other studies. However, the correlation in our study was only weak with correlation coefficients below 2.5. Moreover, in the Cox regression modelling all interaction terms between MPA treatment and clinical variable were included. Ploidy-related rather than receptor-related differences were picked-up as predictors for prognosis in a MPA-treatment dependent fashion.

Another explanation may be, that aneuploid tumours have lost their ability to respond to MPA treatment due to other mechanisms than the loss of receptor. MPA has been shown to modify multidrug resistance ${ }^{35}$. The CAF regimen contains one cytotoxic agent, doxorubicin, that is sensitive to the activity of the MDR-1-associated p-glycoprotein ${ }^{36}$. Patients with MDR-1-positivity can be expected to become more sensitive to CAF if the mechanism, by which MPA can revert MDR is intact. Clearly, diploid and aneuploid tumours are not equally sensitive to CAF as evidenced by the difference in prognosis in the univariate analysis. Studies relating CAF adjuvant effects to MDR status are needed to determine, whether this is due to differences in MDR-positivity. The RR for DMFS and OS is close to 1 for aneuploid versus diploid tumours in the not MPA-treated group, suggesting that MDR per se does not play a major role in the differences, observed once MPA is added. This latter, predictive effect could however be explained by assuming that not the MDR-status itself, but the MDR modulating effect of MPA is different in diploid versus aneuploid cells. Further studies are needed to explore this intriguing possibility.

The role of the SPF in predicting the prognosis and therapy effect is probably small, if

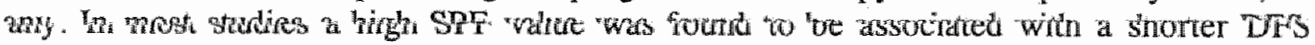
and/or OS time $8.12,19,30,37-39$. In some studies the SPF turned out to be a more powerful prognostic factor than DNA ploidy ${ }^{12.3738,40}$, however, in other reports the independent prognostic value of SPF was lost when the histological grade was included in the analysis ${ }^{13,37,41}$. A number of studies did not include (because of unknown reasons) SPF in their flow cytometric investigation ${ }^{10,12.28,42-46}$. If MPA treatment is taken into account it appears, that particularly patients with $\mathrm{SPF} \geq 8 \%$ benefit from this treatment. This should not be taken to indicate, that high proliferation predicts MPA sensitivity. The results were obtained against a background of treatment with CAF for all patients. The results therefore could also be related to differential sensitivities of high and low proliferative cells to chemotherapy with equal sensitivity to MPA. The survival curves suggest that CAF alone is not very active in highly proliferative tumours. Whether this is true can only be demonstrated from studies with a no treatment arm.

In this study ploidy is independently correlated with age, ER and PgR content. No correlation can be observed between ploidy and SPF or between SPF and steroid- 
receptor content.

In the literature discrepancies are described in correlation between ploidy and axillary nodal status ${ }^{29,42,55,47-49}$, and between ploidy and ER-status ${ }^{10,11,28,42,47,48,50-53}$.

Reports on correlations of nodal status with SPF are conflicting as well ${ }^{47.49-52}$. More unequivocal results are found in reports about correlations between SPF and ploidy ${ }^{41,48,50,54}$.

Although in our study as in others the number of tumour containing axillary nodes, steroid-receptor status, and age are useful prognostic factors in node-positive breast cancer patients, individual decision making and individualizing adjuvant therapy remain difficult. Parameters derived from DNA flow cytometry do not have a major contribution in this respect. Additional reliable prognostic factors, studied prospectively in a homogenous patient population, are needed to individualize adjuvant therapy for nodepositive breast cancer patients. 


\section{REFERENCES}

1 Fisher B, Bauer M, Wickerham DL et al. Relation of number of positive axillary nodes to the prognosis of patients with primary breast cancer. Cancer 1983; 542: 1551-1557.

2. Fisher B, Slack NH, Bross IDJ et al. Cancer and the breast: size of the neoplasm and prognosis. Cancer 1969; 24: 1071-11080.

3 Valagussa $\mathbb{P}$, Bonadonna $G$, Veronesi $U$. Patterns of relapse and survival following radical mastectomy. Cancer $1978 ; 41: 1170-1178$.

4 Fisher B, Redmond C, Fisher ER at al. Relative worth of oestrogen and progesteronereceptor and pathollogic characteristics of differentiation as indicators of prognosis in node-negative breast cancer patients: findings from National Surgical Adjuwant Breast and Bowel Project Protocol B-06. J Clin Oncol 1988; 6: 1076-1087.

5 Knight $V A$, Livingston $R B$, Gregory $E J$ et al. Oestrogen-receptor as an independent prognostic factor for early recurrence in breast cancer. Cancer Res 1977; 37: 4669 4671.

6 Clark GM, MoGuire WL, Hubay CA et al. Progesterone-receptors as a prognostic factor in stage II breast cancer. N Engl I Med 1983; 309: 1343-1347.

7 Raemaekers JIM, Beex LVAM, Pieters GFFM et al. Progesterone-receptor activity and the relapse-free survival in patients with primary breast cancer: the role of adjuwant chemotherapy. Breast Cancer Res Treat 1987; 9 (3): 191-199.

8 Hedley DW, Rugg CA and Gelber RD. Association of DNA index and S-phase fraction with prognosis of $\mathrm{N}+$ early breast cancer. Cancer Res $1987 ; 47 ; 4729-4735$.

9 Hedley DW. Flow cytometry using paraffin-embedded tissue: five years on. Cytometry 1989; 10: 229-241.

10 Beerman $H$, Kluin PM, Hermans $J$ et al. Prognostic significance of DNA ploidy in a series of 690 primary breast cancer patients. Int J Cancer 1990; 45: 34-39.

11 Kalloniemi OP, Blanco $G$, Alavaikko $M$ et al. Tumour DNA ploidy as an independent prognostic factor in breast cancer. $\mathrm{Br} \mathrm{J}$ Cancer $1987 ; 56: 637-642$.

12 Clark GM, Dressler LG, Owens MA et al. Prediction of relapse of survival in patients with node-negative breast cancer by DNA flow cytometry.

N Engl J Med 1989; 320: 627-633.

13 O'Reilly SM, Camplejohn RS, Barnes DM et al. DNA index, S-phase fraction, histological grade and prognosis in breast cancer. Br J Cancer 1990; 61: 671-674.

14 Clatk GM, Mathieu MC, Owens MA et al. Prognostic significance of S-phase fraction in good risk, node-negative breast cancer patients. J Clin Oncol 1992; 10; 428-432.

15 Stanton PD, Cooke TG, Oakes SJ et al. Lack of prognostic significance of DNA ploidy and S-phase fraction in breast cancer. Br J Cancer 1992; 66: 925-929.

16 O'Reily SM, Barnes DM, Camplejohn RS et al. The relationship between c-erbB-2 expression, $S$-phase fraction and prognosis in breast cancer.

Br ICancer 1991; 63 (3): 444-446.

17 Kute TE, Muss HB, Cooper MR et al. The use of flow cytometry for the prognosis of stage II adjuvant treated breast cancer patients. Cancer $1990 ; 66(8): 1810-1816$.

18 Bloom HJG, Richardson WW. Histologic grading and prognosis in breast cancer.

Br J Cancer 1957; 11: 359-377.

19 Scatchard $\mathrm{G}$. The attraction of proteins for small molecules and ions.

Amn NY Acad Sci 1949; 51: 660-672.

20 Lowry DH, Rosenbrough WJ. Farr et al. Protein measurement with the folin phenoll reagent. J Biol Chem 1961; 193: 265-275.

21 Schutte B, Reynders MMJ, Bosman FTG et al. Flow cytometric determination of DNA ploidy level in isolated nuclei from paraffin embedded tissue. Cytometry 1986; 6: 26-30. 
22 Vindelov LL, Christensen U, Nissen NI. A detergent trypsin method for the preparation of nuclei for flow cytometric DNA analysiis. Cytometry $1983 ; 3: 323-327$.

23 Hiddeman $W$, Schumann J, Andreeff $M$ et al. Convention of nomenclature for DNA cytometry. Cytometry $1984 ; 5: 445-446$.

24 Ewens SB, Langstrom E, Baldedorp B et al. Flow cytometric DNA analysis in primary breast carcinomas and clinicopathological correlation. Cytometry $1984 ; 5 ; 408-419$.

25 Coulson PB, Thornthwaite IT, Woolley TW et al. Prognostic indicators including DNA histogram type, receptor content, and staging related to human breast cancer patient surwival. Cancer Res 1984; 44: 4187-4196.

26 McGuire WL, Dressler LG. Emerging impact of flow cytometry in predicting recurrence and survival in breast cancer patients. I Natl Cancer Inst 1985; 75: 405-410.

27 Thorud E, Fossa SD, Vaage $S$ et al. Primary breast cancer. Flow cytometric DNA pattern in relation to clinical and histopathological features. Cancer 1986; 57: 808-811.

28 Cornelisse $\mathrm{CJ}$, van de Velde CJ, Caspers RJ et al. DNA ploidy and survival in breast cancer patients. Cytometry $1987 ; 8: 225-234$.

29 Fallenius AG, Auer GU, Carstensen JM. Prognostic significance of DNA measurements in 409 consecutive breast cancer patients. Cancer $1988 ; 62: 331-341$.

30 Eskelinen MJ, Pajarinen P, Collan $\mathrm{Y}$ et al. Relationship between DNA ploidy and survival in patients with primary breast cancer. Br J Surg 1989; 76: 830-834.

31 Toikkanen $S$, Joensuu $H$, Klemi $P$. Nuclear DNA content as a prognostic factor in $T_{1-2} N_{03}$ breast cancer. Am J Clin Pathol 1990; 93:471-479.

32 Uyterlinde AM, Schipper NW, Baak JP et al. Limited prognostic value of cellular DNA content to classical and morphological parameters in invasive ductal breast cancer.

Am J Clin Pathol 1988; $89: 301-307$.

33 Dowle CS, Owainati A, Robins A et al. Prognostic significance of the DNA content of human breast cancer. Br J Surg 1987; 74: 133-136.

34 Keyhani-Rofagha S, O'Toole RV, Farrar WB et al. Is DNA ploidy an independent prognostic indicator in infiltrative node-negative breast adenocarcinoma.

Cancer 1990; 65: 1577-1582.

35 Huang Yang C-P, Goei De Pinho S, Greenberger LM, Arceci RJ and Band Horwitz S. Progesterone interacts with P-glycoprotein in multidrug-resistant cells in the endometrium of gravid uterus. IJ Biol Chem 1989; 264: 782-788.

36 Rao US, Fine RL $_{\mathrm{i}}$ Scarborough GA. Antiestrogens and steroid hormones: substrates of the human P-glycoprotein. Biochem Pharmacol 1994; 48 (2): $287-292$.

37 Kallioniemi DP, Blanco G, Alavaikko $M$ et al. Improving the prognostic value of DNA flow cytometry in breast cancer by combining DNA index and S-phase fraction. A proposed classification of DNA histograms in breast cancer.

Cancer 1988; 62: 2183-2190.

38 Sigurdsson $\mathrm{H}$, Baldetorp $\mathrm{B}$, Borg $\mathrm{A}$ et al. Indicators of prognosis in node-negative breast cancer. N Engl J Med 1990; 322: 1045-1053.

39 Winchester DJ, Duda RB, August CZ et al. The importance of DNA flow cytometry in node-negative breast cancer. Arch Surg 1990; 125: 886-889.

40 Hatschek T, Fagerberg G, Stal O et al. Cytometric characterization and clinical course of breast cancer diagnosed in a population based screening program.

Cancer 1989; 64: 1074-1081.

41. Muss H, Kute T, Case D et al. The relation of flow cytometry to clinical and biollogic characteristics in women with node-negative primary breast cancer.

Cancer 1989; 64: 1894-1900.

42 Hedley DW, Rugg CA, Ng ABP and Taylor IW. Influence on cell DNA content on DFS of stage II breast cancer patients. Cancer Res 1984; 44: 5395 5398. 
43 Stuari-Harris R, Hedley DW, Taylor IW et al. Tumour ploidy, response and survival in patients receiving endocrine therapy for advanced breast cancer.

Br J Cancer 1985; 51: 573-576.

44 Merkel DE, Dressler LG and McGuire WL. FCM, cellular DNA content and prognosis in human malignancy. I Clin Oncol 1987; 5: 1690-1703.

45 Arnerlơv $\mathrm{C}_{4}$ Edmin $\mathrm{SO}$, Roos $\mathrm{G}$ et al. Prognostic factors in locally advanced breast cancer $\left(\mathrm{T}_{3}, \mathrm{~T}_{4}\right)$ with special reference to cell DNA content.

Acta Oncol 1988; 27: 221-226.

46 Edward Lewis W. Prognostic significance of flow cytometric DNA analysis in nodlenegative breast cancer patients. Cancer 1990; 65: 2315-2320.

47 Koike H. The impact of DNA ploidy and proliferation index on survival of breast cancer patients. Mie Med J 1988; $111-124$.

48 Feichter GE, Müller A, Kaufmann M et al. Correlation of DNA flow cytometric results and other prognostic factors in primary breast cancer. Int J Cancer 1988; 41: 823-828.

49 Uyterlinde AM, Schipper NW and Baak JP. Comparison of extent of disease and morphometric DNA FCM prognostic factors in invasive ductal breast cancer.

J Clin Pathol 1987; 40: 1432-1436.

50 Kute TE, Muss HB, Hopkins $M$ et al. Relationship of FCM results and steroid-receptors in human breast cancer. Breast Cancer Res and Treatm 1985; 6: 113-121.

51 McDivitt RW, Stone KR, Craig B et al. A proposed classification of breast cancer based on kinetic information. Cancer 1986; 57: 269-276.

52 Helin HJ, Markku HJ, Kallioniemi O-P and Isola JJ. Immunohistochemical determination of oestrogen and progesterone receptors in human breast carcinoma.

Cancer $1989 ; 63: 1761-1767$.

53 Merkel DE, Dressler LG, McGuire WL. FCM, cellular DNA content and prognosis of human malignancy. J Clin Oncol 1987; 5: 1690-1703.

54 Dressler LG, Seamer LC, Owens CA et al. DNA flow cytometry and prognosis in 1331 frozen breast cancer specimens. Cancer 1988; 61: 420-427. 


\section{PLOIDY AND S-PHASE FRACTIONS (SPF) OF PRIMARY BREAST CANCERS AND THEIR NODAL METASTASES}

$P$ Hupperets, B Schutte, C van Assche, L Schouten, J Jager, J de Jong, G Blijham

Breast Cancer Research and Treatment. 1994; 32: 197-202 


\section{PLOIDY AND S-PHASE FRACTIONS (SPF) OF PRIMARY BREAST CANCERS AND THEIR NODAL METASTASES}

\section{SUMMARY}

Ninety-one cases of primary breast cancers and their nodal metastases were examined with DNA flow cytometry. No differences were found between the stemline distributions in the primary tumours and nodal metastases. At both sites stemlines clustered around a DNA index of $1.0(33-40 \%$ of cases) and 1.8 .

The mean $S$-phase fractions were 7.9 in primary tumours versus $5.6 \%$ in nodal metastases $(p=0.02)$; this difference was also observed if the analysis was restricted to cases with DNA aneuploidy at both sites $(10.2$ versus $7.6 \%, p=0.04)$. Our results indicate that axillary nodal ploidly and proliferation reflect primary tumour characteristics rather than display changes associated with selection during the Iymphatic metastatic process. Lymph nodes may have a suppressive effect on the proliferation of tumour cells.

\section{INTRODUCTION}

In primary breast cancer DNA flowcytometry (FCM) provides reproducible information regarding DNA content (ploidy) and proliferation (S-phase fraction or SPF). In most studies these tumour-associated characteristics were found to predict for prognosis $1,2,3,4,5$ although this has not been universally observed or was limited to subsets of patients ${ }^{6,7,8,9}$. One factor that may contribute to the inconsistency of these results is intratumour heterogeneity. Tumour containing axillary lymph nodes, because of the occurrence of selection towards metastatic subpopulations, may provide different and prognostically more relevant information regarding ploidy and proliferation characteristics. As a first step towards answering this question we performed DNA FCM on archival material from 91 primary breast cancers and their axillary nodal metastases and compared ploidy and proliferation at these two sites.

\section{MATERIAL AND METHODS}

Ninety-one cases with histologically proven node-positive primary breast cancer were examined. They represent all consecutive cases that were contributed by one institution to a multicenter trial of the addition of medroxyprogesterone acetate to adjuvant chemotherapy with cyclophosphamide, doxorubicin and 5-fluorouracil (FAC) ${ }^{10}$. Fifty $\mu \mathrm{m}$ sections were cut from formalin-fixed paraffin-embedded tissue blocks containing at least one sample of the primary tumour and one sample of a nodal metastasis. Four $\mu \mathrm{m}$ cut in 
continuity with the $50 \mu \mathrm{m}$ sections were Haematoxylin-Eosin (H-E) stained and were used for histologic control. The analysis was restricted to axillary nodes of which at least $25 \%$ of the cut surface as visualized by $\mathrm{H}-\mathrm{E}$ staining was occupied with tumour. This percentage was visually evaluated on $\mathrm{H}-\mathrm{E}$ slide. Infiltrates of lymphocytes in the tumour were not taken into account. Single nuclear suspensions were made from the $50 \mu \mathrm{m}$ sections according to a method described ${ }^{11}$. In brief, the sections were placed in $10 \mathrm{ml}$ centrifuge tubes and dewaxed in $6 \mathrm{ml}$ xylene for 15 minutes at room temperature. Rehydration was performed in a sequence of $100 \%, 96 \%, 70 \%$ and $50 \%$ ethanol with centrifugation and decantation of the supernatant after each step. The sections were washed in $5 \mathrm{ml}$ phosphate-buffered saline (PBS, pH 7.4). Three $\mathrm{ml} \mathrm{of} 0.25 \%$ trypsin (DIFCO) in citrate buffer ( $3 \mu \mathrm{m}$ trisodium citrate, $0.1 \%$ nonidet $\mathrm{P} 40,1.5 \mathrm{mM}$ spermine tetrachloride, $0.5 \mathrm{mM}$ Tris $\mathrm{pH} 7.6$ ) was added and the tubes were incubated overnight at $37^{\circ} \mathrm{C}$. After vortex mixing the sample was filtered through a $50 \mu \mathrm{m}$ nylon mesh. Approximately $2-3 \times 10^{6}$ nucllei were stained according to the method of Vindelov et al. ${ }^{11}$

\section{FLOW CYTOMETRY}

Cellular DNA content was measured on a FACS IV Cell Sorter (Becton and Dickinson, Sunnyvalle, CA) equipped with a 4W Argon laser (Spectra Physics, model 164-01) operating at $488 \mathrm{~mm}$. Histograms of $10^{4}$ cells were recorded. Deviations in cellular DNA content (aneuploidy) were expressed as the DNA index (DI). The DI was calculated as the ratio of aneuploid to diploid G1/O peak channel; in case of $\geq 2$ peaks the left-sided was always considered as diploid. DNA indices between 0.9 and 1.1 are considered to be diploid; between 1.9 and 2.1 tetraploid; $>2.1$ hypertetraploid and the remaining DNA indices are considered aneuploid. Histograms with coefficients of variation less than $8 \%$ were considered of good quality. The proliferative activity was calculated by visually marking the area between the right inclination of the Gl and the left inclination of the G2M peak and counting the number of cells between these markings. The visually marked SPF calculation was performed by two individuals separately. In around $60 \%$ of all DNA histograms SPF can be calculated. In cases of less than $30 \%$ admixture of diploid cells, the percentage of aneuploid S-phase cells was calculated without corrections for presence of diploid $S$ - and $\mathrm{G} 2 / \mathrm{M}$ phase cells. In case of more than $30 \%$ admixture of diploid cells and overllap of diploid and hyperdiploid histograms the percentage of $S$-phase cells was not calculated.

\section{STATISTICS}

S-phase fractions from primary tumours and axillary metastases were compared using a one way anova or, if there was a concordant DI at both sites, a paired t-test. 


\section{RESULTS}

Results from ploidy analyses in 91 cases of primary breast cancer are shown in figure 1 as the frequency distributions of DNA stemlines from primary tumours and their nodal metastases. The diploidy rate was slightly higher in lymph nodes (40\% versus $33 \%$, $p<0.05$ ) and at both sites the DNA indices clustered in the 1.0 and 1.8 range. If analyzed for DNA-index correlations at the level of individual patients only 39/91 (43\%) of cases showed identical DNA ploidy clones in the primary tumour and their nodal metastases. This result has to be interpreted, however, against our finding of a $41 \%$ sampling variability in DNA ploidy from different biopsies of the same primary tumour.

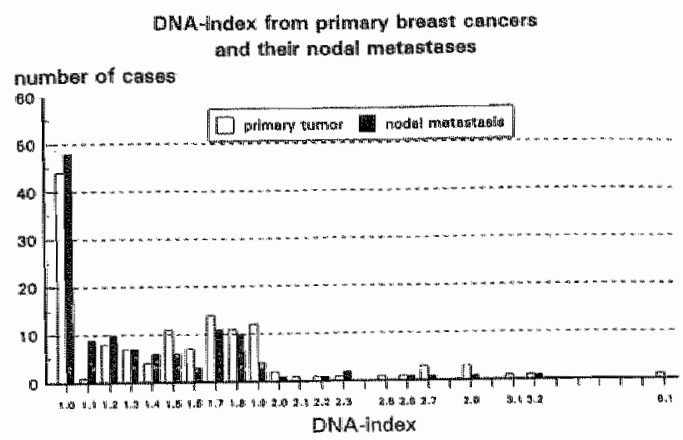

Figure 1 Frequency distribution of DNA stemlines from primary tumours and their nodal metastases.

S-phase fractions (SPF) could be determined in all diploid cases $(n=20)$, in 6 cases with a diploid primary tumour and aneuploid nodal metastases, 6 cases with aneuploid primary and diploid node, 6 cases with concordant aneuploidy at both sites and 2 cases with discordant aneuploidy. The frequency distribution is shown in figure 2 for primary tumours and metastatic axillary nodes. Since these data suggest an overall lower nodal SPF as compared to the primary tumour, we further analyzed this relationship in more detail; the results are presented in table I. A significant difference was observed with the SPF of the primary tumour exceeding that of the metastatic node with $2.3 \%$. If the analysis was restricted to cases with concordant ploidy (diploid or aneuploid at both sites) the differences remained of the same order of magnitude and were significant, even in the case of aneuploid tumours with a very small sample size (table D). For the interpretation of these data it is important to know the background of SPF of not tumourcontaining lymph nodes. Therefore, 13 samples from node-negative breast cancer patients were also analyzed. Their mean SPF was $4.8 \%$ (range: $2.3-8.7$; SEM 1.6). 


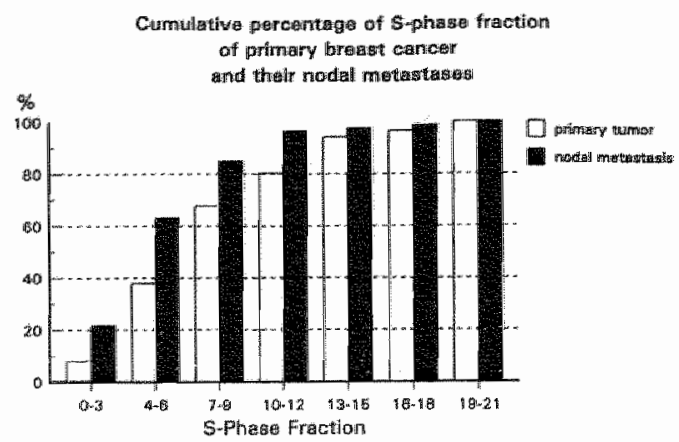

Figure 2 Cumulative percentage of S-phase fraction of primary breast cancer and their nodal metastases.

Table I S-phase Fractions in Primary Breast Cancer and Nodal Metastases: Comparison.

\begin{tabular}{llllll}
\hline & \multicolumn{2}{c}{ SPF $(\%)$} & p-value** & correlation coeff. \\
& No & primary & node & & \\
\hline all cases (SEM)* & 40 & $7.86(0.70)$ & $5.69(0.60)$ & $<0.01$ & $0.5403(\mathrm{p}<0.05)$ \\
cases with DI $=1.0$ & 26 & $6.83(0.61)$ & $4.63(0.64)$ & $<0.01$ & $0.5584(\mathrm{p}<0.05)$ \\
cases with DI\#1.0 & 14 & $10.46(1.908)^{*}$ & $7.58(1.40)^{*}$ & $<0.04$ & $0.7242(\mathrm{p}<0.05)$ \\
\hline
\end{tabular}

* SPF determination possible on all diploid and 20/45 (44\%) of aneuploid cases.

** paired t-test for cases with concordant DNA-index

Despite the differences in SPF between primary tumours and nodal metastases a significant correlation between the SPF at the two sites could be demonstrated, in particular if the analysis was limited to cases with concordant stemlines. This is shown in figure $3 \mathrm{a}$ for diploid/diploid stemlines and in figure $3 \mathrm{~b}$ for aneuploid/aneuploid. stemlines. In both instances significant correlation coefficients were obtained of 0.56 and 0.72 respectively $(p<0.05)$. Taken logether these data indicate, that the proliferative characteristics of a breast tumour are maintained in the process of regional nodal metastasis albeit at a lower level of activity. 


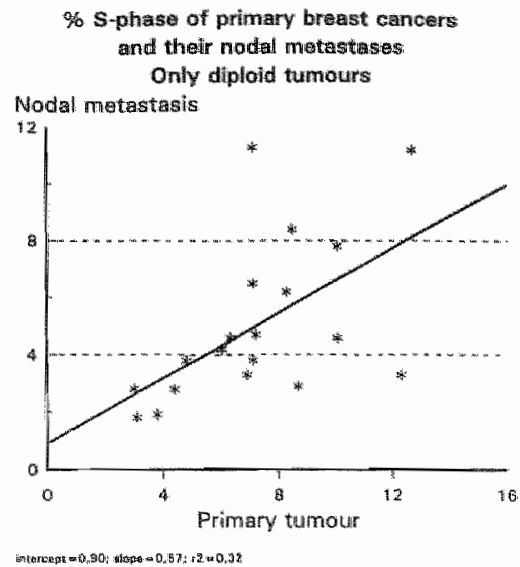

Figure 3a Correlation between SPF of primary tumours and tumour containing lymph nodes in diploid tumours

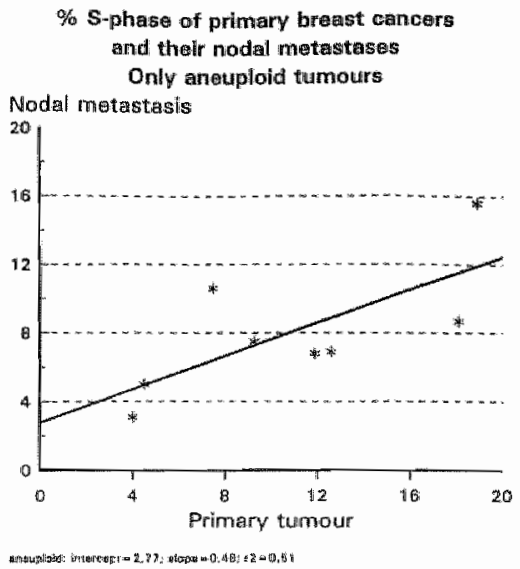

Figure 3b Correlation between SPF of primary tumours and tumour containing lymph nodes in aneuploid tumours

\section{DISCUSSION}

In this large series of patients with primary breast cancer and axillary nodal metastases no differences could be observed between the distribution of stemlines in primary tumours and their nodal metastases. Similar results have been described by other investigators ${ }^{12-16}$. At the level of individual patients complete concordance of stemlines between primary tumour and axillary nodes was observed in only $43 \%$ of cases. This figure however is difficult to interpret because of considerable sampling variability. Beerman et al ${ }^{16}$ found intra-tumour heterogeneity (and therefore sampling variability) in $80 \%$ of primaries and $66 \%$ of axillary nodal metastases; with the examination of 2 rather 
than 1 nodal sample we obserwed a $41 \%$ chance of finding an additional stemline. Therefore the difference in DNA ploidy between individual primary tumours and their nodal metastases can well be caused by intra-tumour heterogeneity. The similar stemline distribution profiles at both sites certainly suggest that if clonal selection occurs during the metastatic process, this does not result in clonal restriction as expressed in flow cytometrically measured DNA content.

In contrast to others ${ }^{12,13}$ we found the nodal SPF to be significantly lower than the SPF of the corresponding primary tumours. One obvious explanation of this finding would be dilution effect due to the admixture with non-malignant nodal cells (e.g. lymphocytes) with a low proliferation rate. We consider it unlikely that this is the sole explanation for two reasons. Firsty, the difference was also apparent if the analysis was restricted to cases with aneuploid stemlines in both the primary tumour and their axillary nodes. In fact, the difference was even somewhat greater than with diploid tumours and probably only less significant $(p=0.04)$ because of the small sample size. It is difficult to imagine how a dilution effect may explain the SPF difference in this circumstance. Secondly, the mean SPF of tumour-negative axillary nodes equalled that of tumour-positive nodes in cases of diploid tumours. Most of the metastatic nodes contained a considerable amount of tumour; we selected nodes with at least $25 \%$ of the cut surface consisting of tumour and often this percentage was considerably higher. Therefore, the mixture of nonmalignant lymph node cells with a SPF of $4.8 \%$ and malignant diploid cells with a SPF of $6.8 \%$ (as is the case in the primary tumours with a diploid stemline) should have resulted in a higher SPF in the metastatic nodes than the observed $4.6 \%$. This again points clearly to the fact that nodal tumour cells indeed have a lower proliferation rate as. compared to their primary counterparts. Obviously a final demonstration of this phenomenon would require the presence of a second marker, that would allow to restrict the measurement of proliferation to clearly defined malignant cells. Such an approach could not be applied in our study that makes use of quantitative DNA measurements on isolated nuclei but may become feasible by combining other proliferation markers with phenotypic markers of malignancy ${ }^{19}$.

We did not apply one of the recently developed computer programs to calculate the SPF. Such programs use mathematical models to determine the SPF, in some cases account for the presence of debris and may give results in cases that in the method of manual gating is considered not suitable for reliable SPF-calculations. Recent comparative investigations have explored the various methodologies ${ }^{20.21}$. In a study of non-Hodgkin's Iymphomas the manual gates model yielded an accurate SPF estimate in most cases and was not inferior than computer models with rectangular or polynomial fit and debris subtraction. Also, it is clear from our own experience and from data in the literature that sampling variations by far exceed the variations introduced by the different methods of calculating S-phase fractions in a given histogram. Therefore, computer-aided S-phase analysis has the advantage of greater objectivity but not necessarily of greater accuracy. The choice of the appropriate algorithm depends on the histogram to be analyzed and may be subjective. Manual gating remains an acceptable and reliable alternative. 
The nodal SPF, though significantly lower, at the same time correlated significantly with the primary SPF and the distribution profile of the nodal SPF, though shifted to the left, appeared similar. If tumour cells with a low proliferative potential had a higher propensity to metastasize, one would expect the distribution profile to show a more enhanced clustering around lower values and the scatterplots to diverge from a straight line. Clearly neither is the case. It appears, therefore, that the lower nodal SPF is not the result of metastatic selection, but rather is determined by both the inherent proliferative capacity of the primary stemline and the metastatic environment, that in axillary nodes appears to be suppressive for proliferation.

In conclusion, axillary nodal ploidy and proliferation reflect primary tumour characteristics rather than display changes associated with the metastatic process; the lymph node, however, may be suppressive for proliferation. In view of these findings it appears reasonable to hypothesize, that calculation of the proliferative rate of thmour containing axillary lymph nodes will have no prognostic impact over that obtained from the primary tumour. A follow-up study on a larger population is needed to investigate this hypothesis in a more definitive way. 


\section{REFERENCES}

1 Hedley DW, Rugg CA and Gelber RD. Association of DNA index and S-phase fraction with prognosis of node-positive early breast cancer. Cancer Res 47: 4729-4735, 1987.

2 Comelisse CJ, van de Velde CJH, Caspers RIC, Molenaar SJ, Hermans Y. DNA ploidy and survival in breast cancer patients. Cytometry 8: 225-234, 1987.

3 Beerman H, Klein PhM, Hermans $J$, wan de Velde $\mathrm{CJ}$, Cornelisse CJ. Prognostic significance of DNA ploidy in a series of 690 primary breast cancer patients.

Int J Cancer 45: 34-39, 1990.

4 Eskilinen MJ, Pajarinen P, Collan $Y$, Pesonen E, Alhana $\mathbb{E}$, Kettunen $K$, Nordling $\mathrm{S}$. Relationship between DNA ploidy and surwival in patients with primary breast cancer.

Br J Cancer 61: 671-674, 1990.

5 Kallioniemi OP, Blanco $G$, Alavaikko M, Hietanen $T$, Matilla $\mathbb{I}$, Lauslahti $H$, Lehtinen $M$ and Koivula $T$. Improving the prognostic value of DNA flow cytometry in breast cancer by combining DNA index and S-phase fraction: a proposed classification of DNA histograms in breast cancer. Cancer 62: 2183-2190, 1988.

6 Muss H, Kute T, Case D, Smith R, Boder C, Long R, Kammuire L, Gregory B and Brockschmidt $M$. The relation of flowcytometry to clinical and biological characteristics in women with node-negative primary breast cancer. Cancer 64: 1894-1900, 1989.

7 Hedley DW, Rugg CA, Ng ABP and Taylor IW. Influence of cellular DNA content on disease-free survival of stage II breast cancer patients. Cancer Res 44:395-398, 1984.

8 Toikkanen $S$, Joenssuu $H$ and Klemi $P$. Nuclear DNA content as a prognostic factor in $\mathrm{T}_{1-2} \mathrm{~N}_{0}$ breast cancer. Am J Clin Pathol 93: 471-479, 1990.

9 Sigurdsson H, Baldetorp B, Boro A, Dalberg M, Fernö M, Killander D and Olsson H. Indicators of prognosis in node-negative breast cancer.

N Engl J Med 322: 1045-1053, 1990.

10 Blijham GH, Wils J, Schouten L, Hupperets P, Jager J, de Jong $J$, von Meyenfeldt $M$, Fickers $M$ and Bron $\mathrm{H}$. Adjuvant therapy with high-dose medroxyprogesterone acetate (MPA) if added 10 chenotherapy in patients with node-positive operable breast cancer. Annals of Oncology 1: 19, 1990 .

11 Vindeløv LL, Christensen IJ, Nissen NJ. A detergent trypsin method for the preparation of nuclei for flow cytometric DNA analysis. Cytometry 3: 323-327, 1983,

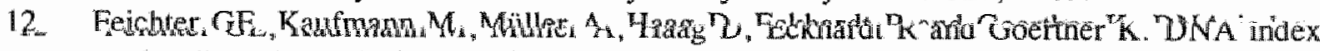
and cell cycle analysis on primary breast cancer and synchronous axillary lymph node metastases. Breast Cancer Res Treat 13: 17-22, 1989.

13 Olszewskii W, Darzynkiewicz Z, Rosen PP, Clapss ML and Melamed MR. Flow cytometry of breast carcinoma: III.

Possible altered kinetics in metastases. Anal Quant Cytol 4: 275-279, 1982.

14. Hitchcock A, Ellis IO, Robertson JFR, Gilmour A, Bell J, Elston CW and Blamey RW. An observation of DNA ploidy, histological grade and immunoreactivity for tumour related antigens in primary and metastatic breast carcinoma. I Pathol 159: 129-134, 1989.

15 Del Bino $G$, Silvestrini $R$, Zucconi $M R$, Marchese $G$, Valentinis $B$, Di Fronzo $G$ and Andreolat $S$. DNA ploidy of human breast cancer. Anal Cell Pathol 1: 215-223, 1989.

16 Beeman H. Smitl VTHBM, Klein PhM, Bonsing BA, Hermans J and Comelissen CJ. Flow cytometric analysis of DNA stemline heterogeneity in primary and metastatic breast cancer. Cytometry 12: 147-154, 1991.

17 Arends JW, Schutte B, Wiggers $T$, Verstijnen $C$, Blijham GH and Bosman FT. Comparison of phenotypic and genotypic features in primary large bowel carcinomas and lymph node metastases. Cancer Res 47: 4342-4344, 1987. 
18 Dressler LG, Seamer LC, Owens MA, Clark GM and McGuire WL. DNA flow cytometry and prognostic factors in $133 \perp$ frozen breast cancer specimens.

Cancer 61: $420-427,1988$.

19 Theunissen PHMH, Leers MPG and Bollen CM. Proliferating cell nuclear antigen (PCNA) expression in formalin-fixed tissue of non-small cell lung cancer. Histopathology 20: 251-255, 1992.

20 Beauregard P, Witzig TE, Kurtin PJ et al. Models of S-phase determination in lymphomas from flow cytometric DNA content histograms: comparison with the bromodeoxyuridine labeling index. Hematol Pathol 5 (4): 177-183, 1991.

21 Kute TE, Ziberanski $\mathbf{N}$, Muss $\mathbf{H}$ and Cirrincione. Flow cytometry (FC) analysis in nodepositive breast cancer. A CALGB experience.

Breast Cancer Research and Treatment 23: 135, 1992 (abstract). 


\section{SUMMARY AND GENERAL DISCUSSION}




\section{SUMMARY AND GENERAL DISCUSSION}

\section{INTRODUCTION}

Breast cancer is a heterogeneous and complex disease for which in the near future no dramatic improvement in survival is to be expected in terms of current therapeutic concepts. The greatest impact on disease free survival and survival, during the last 30 years, has been achieved with adjuvant treatment with multi-agent chemotherapy, prolonged tamoxifen treatment and the combination of chemo- and endocrine treatment ${ }^{\mathrm{l} .2}$.

The last decade has witnessed a large increase in the size of biologic information relating to normall and abnormal breast development. The use of molecular techniques in combination with refined methods of histologic assessment have provided information about genetic changes during the development of the malignant process, about factors that influence cell proliferation and about factors that are prognostic of outcome. A number of most widely used factors are summarized in table $\mathbb{I}$. However, despite this surge in new prognostic variables, the therapeutic options now available to a woman who is diagnosed to have breast cancer, have been derived empirically, and in general they have not been refined by the impact of biological factors.

In this study on node-negative and node-positive breast cancer patients, in which diagnosis, staging and loco-regional therapy was performed uniformly, we attempted to relate clinical and biologic properties (PTNM, number of involved axillary nodes, steroid-receptor status, DNA-index, S-phase percentage and age) and aspects of treatment to the subsequent prognosis and response to treatment in human breast cancer. The results will be summarized and discussed in view of their practical applications and significance for further studies.

Table 1 A number of prognostic indicators in breast cancer

\begin{tabular}{|c|c|c|c|}
\hline Prognostic Factior & Relevant to Etiology & Giuide to Therapy & Reference \\
\hline Nodal status & No & Yes & Fisher ef all. ${ }^{3}$ \\
\hline Tumour size & No & Yes & Neville et all." \\
\hline Nuclear grade & No & Yes & Neville ef all. \\
\hline Oestrogen and progesterone receptor & Possibly & Yes & Fisher et al. \\
\hline $\begin{array}{l}\text { Ploidy } \\
\text { Pla }\end{array}$ & Possibly & No & O'Reilly\&Rinards ${ }^{5}$ \\
\hline S-phase fraction & No & Possibly & $\begin{array}{c}\text { O'Reilly\&Richards }^{5} \\
\text { Gasparimi et al. }\end{array}$ \\
\hline
\end{tabular}




\section{ADJUVANT CHEMO-HORMONAL TREATMENT}

In Chapter II of the study post-operative chemo-hormonal treatment is compared to chemotherapy alone in node-positive breast cancer patients. Patients $\geq 60$ years showed a significantly longer disease-free survival and overall survival when medroxyprogesterone acetate (MPA) was added to CAF chemotherapy. The beneficial effect may be explained by higher oestrogen-receptor levels $(\mathrm{ER})$ in elderly breast cancer patients. In women $\leq 40$ years the addition of MPA to chemotherapy has a detrimental effect which may be explained by the protective effect of MPA on ovarian function, preventing chemotherapy-induced owarian ablation. A second explanation of the detrimental effect of the combination CAF with MPA could be a decrease in percentage of S-phase cells, caused by MPA, leading to a reduced effect of chemotherapy.

MPA in high dose added to chemotherapy has a beneficial effect in elderly patients on freedom from distant metastases and overal survival. However, side effects of MPA, especially weight gain and local infection from intramuscular administration are of concern. Since low dose MPA (300 mg p.o.) has the same remission rate in comparison to high dose MPA (900 mg p.o.) $)^{7}$, a low oral dose could be chosen in an adjuvant treatment schedule in order to ameliorate these side effects. High dose MPA (500-1000 $\mathrm{mg}$ p. 0 . or i. $\mathrm{m}_{\text {.. }}$ ) was as effective as tamoxifen in adwanced breast cancer in a number of studies.8.10. These data support further exploration of MPA (300-500 mg p.o.) as adjuvant treatment in postmenopausal axillary lymph node-positive breast cancer patients in comparison to tamoxifen $20 \mathrm{mg}$.

Adjuvant tamoxifen treatment is used post-chemotherapy in a dosage of $20 \mathrm{mg}$ during 2-3 years. Data on MPA adjuvant treatment started after chemotherapy and administered for longer than 6 months are not available. Tamoxifen has interesting other side effects such as on the bone and the cardiovascular system ${ }^{11,2}$. It also reduces the incidence of contralateral breast cancer but may increase the risk for endometrial cancer ${ }^{13}$. This later effect is absent with MPA; recently this drug has been found to be as effective as tamoxifen to prevent contralateral breast cancer $^{14}$.

Taken together it certainly is too early to replace anti-oestrogens with progestagens in the adjuvant treatment of node-positive postmenopausal breast cancer patients. If the efficacy of the two approaches is indeed similar, other factors such as oncological and nononcological side effects become important. Trials comparing long term tamoxifen with short and long term oral progestagens are needed to address these issues.

\section{STEROID-RECEPTOR AND PROGNOSIS}

The steroid-receptor status is in literature mostly studied as a dichotomous variable ( $\leq 10$ fmol/mg protein versus $>10$ ). In chapter III oestrogen- (ER) and progesterone-receptor $(\mathrm{PgR})$ are studied as a continuous variable. Node-negative breast cancer patients with ER-contents between 100 and $400 \mathrm{fmol} / \mathrm{mg}$ protein have a low risk of recurrence whereas the classical (clinically used) cut-off point of $10 \mathrm{fmol} / \mathrm{mg}$ has no significant 
prognostic value in this study. Patients with very high $E R$ levels $(>400 \mathrm{fmol} / \mathrm{mg})$ do significantly worse, but this phenomenon may be influenced by the low number of patients in this subgroup. "These results are time independent and are seen for distant metastasis free survival (DMFS) and overall survival. In node-positive breast cancer patients the ER-status ( $\leq 10$ or $>10 \mathrm{fmol} / \mathrm{mg}$ protein) predicts prognosis in a timedependent fashion, that is in the first 5 years after diagnosis.

The PgR is a time dependent prognostic factor in node-negative patients. Patients with a $\mathrm{PgR}$ content $>80 \mathrm{fmol} / \mathrm{mg}$ protein have more distant metastases and an excess of deaths after a follow-up period of more than 5 years whereas patients with a $\mathrm{PgR}$ content $\leq 80$ fmol/mg have a higher risk up to about 5 years after diagnosis. In node-positive patients a cut-off point of 60 shows to be a significant prognosticator meaning that values $\leq 60$ predict for a higher risk of distant metastasis and death. This effect is time-independent.

Given our data and those from the literature it is very difficult to come to a clear and firm conclusion regarding the use of the steroid-receptor status as a prognosticator for patients with operable breast cancer. Two points, however, seem to emerge. The first is the time-dependency of the prognostic information. In our study low ER-levels in nodepositive and low PgR-levels in the node-negative patients predict a poorer prognosis for the first 5 years after the diagnosis. This effect disappears or is even counter balanced (in. case of $\mathrm{PgR}$ ) after that time. Similar time-dependent effects have been observed by others ${ }^{15}$. The reasons for this are difficult to dissect. Part may be due to a longer survival time after relapse, part to differences in local aggressiveness rather than in metastatic potential, part to transient adjuvant treatment effects.

The second point relates to the definition of cutt-off points. Our results show that prognostic information may get lost if only the traditional cut-off points of positivity and negativity are used. In treating the ER as a continuous variable it was found that patients with very high levels may have a poorer prognosis. Numbers did not permit to analyze these data further regarding the relation with for instance age and MPA treatment effect. However, if this finding is true it may clearly have contributed to the inconsistency of tindings in studies using traditional cut-off points.

Taken together our data show that the steroid-receptor status is a difficult and not altogether reliable prognosticator. Although further and even larger studies would be needed to delineate their role more precisely, however, it can be doubted whether they will even be of major importance in this respect. Their main value may lay in the predictive power for the chance to obtain a positive treatment effect with adjuvant endocrine therapy.

\section{FCM IN NODE-NEGATIVE PATIENTS}

The results of DNA flow cytometry (FCM) in node-negative breast cancer patients are described in chapter IV. Aneuploidy, but not SPF is an independent prognostic factor in multivariate analysis, however, the contribution of ploidy to the determination of the chance for relapse and death is too small to justify its application in routine practice. In contrast to Sigurdsson et al. ${ }^{16}$ we did not find SPF to be an independent prognosticator. This is at least partly caused by the high number of missing SPF in our population. This 
group has a favourable prognosis and if analyzed by a computer model, it would likely have been classified as to belong to the low SPF group. Sigurdsson et al. used a computer program and were able to determine SPF in $90 \%$ (rather than $60 \%$ as in our study) of all cases. If this information is taken into account, the discrepancy between the two studies disappears. A major conclusion from this chapter, therefore, can be, that what one finds regarding the relation between SPF and prognosis depends at least in part on a technical aspect: what has been done with the DNA histograms showing an overlapping aneuploid population of relatively small size. Given this dependency on technical features, the reliability of SPF measurement with this computer-based methodology for breast cancer patients can seriously be questioned.

This is not to say, that proliferation may not be important for the prognosis in breast cancer. Thymidine incorporation studies clearly show this to be the case $\mathrm{e}^{17,18}$ but are laborious. New technologies including the measurement of S-phase associated markers such as PCNA ${ }^{19}$ and the restriction of measurements to tumour cells using a combination of proliferation and cellular markers ${ }^{20}$ should lead to a better understanding of the relation between proliferation and prognosis.

\section{FCM IN NODE-POSITIVE PATIENTS}

Ploidy nor SPF contributed to the prognostic information already given by axillary node status, steroid-receptor status and age. In a more detailed analysis, however, ploidy predicted whether MPA added a more favourable prognosis to CAF adjuvant therapy. Patients with diploid tumours benefitted from MPA as compared to those with aneuploid tumours. Also a suggestion was obtained that in patients with a low SPF $(<8 \%)$ MPA negatively influenced prognosis.

These results, although intriguing, should be viewed with caution. They refer to subgroup analyses and were not obtained in a prospective way. Furthermore, it is not easy to fit these results in our current models of breast cancer biology. They underscore, however, the potential differences between factors with a treatment-independent and treatment-dependent prognostic power, the latter often being called predictive factors. It would be worthwhile to retrospectively analyze other studies with randomized treatment allocations for the predictive effects of ploidy and proliferation. In particular, the trials with a yes or no tamoxifen arm (in addition to chemotherapy or compared to a no treatment arm) are interesting in this respect. If confirmed, our data should form the basis for prospective trials using ploidy and SPF as stratification factors.

\section{PRIMARY TUMOUR AND LYMPH NODES}

Chapter VI describes ploidy and S-phase fraction (SPF) of primary breast cancers and their nodal metastases. This study revealed that differences in DNA ploidy between primary breast cancer and their nodal metastasis can be caused by intra-tumoral heterogeneity. If clonal selection does occur during lymphogenic metastasis, this does not result in to clonal restriction.

Nodal SPF is significantly lower than the SPF in the corresponding primary tumours. 
This cannot be explained by dilution effect due to admixture with non-malignant lymph node cells with low proliferation state. Apparently, the lymph node environment is more favourable to suppress proliferation as the breast tissue itself. This may be due to the presence of stroma-derived stimulators of proliferation in the breast or the active inhibition of proliferation by lymph node derived factors.

In chapter IV and V, but also in chapter VI, calculations of SPF were not aided by computer programs. From our data and from data in the literature, it is clear that sampling variations by far exceed the variations introduced by various methods of calculating SPF in a given histogram. Computer-aided S-phase analysis has the advantage to obtain a SPF in a higher percentage of histograms but not necessarily of greater accuracy.

We conclude from this chapter, that there is no reason to include lymph node FCM in the work-up of patients with node-positive breast cancer.

\section{FINAL REMARKS}

The results of all investigated variables in node-positive breast cancer patients reveals that the number of tumour containing axillary lymph nodes remains the most important prognosticator. ER is a time dependent predictor for DMFS and OS and PgR predicts for DMFS and OS. However, with the prognostic factors we studied, it is impossible to identify reliably the node-positive women with a favourable prognosis for whom adjuvant chemotherapy is not indicated or to predict which group of node-positive patients will not benefit from adjuvant treatment. More reliable prognostic factors are needed to clevelop strategies to predict which $30 \%$ of node-positive breast cancer patients will remain disease-free and which $30 \%$ of node-negative patients are destined to have recurrent disease and which of those may benefit from adjuvant therapies.

Many new prognostic indicators have been described over the past several years and studies are currently ongoing to assess whether any of these indicators may independently predict the likelihood of relapse. This includes the thymidine labelling index ${ }^{21-23}$, expression of growth factor receptors such as the protein product of the HER $2 /$ Neu oncogene $e^{24}$ which is structurally homologous to the EGF-R (epidermal growth factor receptor $)^{25,26}$, the expression of insulin-like growth factor- $1^{27}$, cathepsin D production $^{28}$, and the expression of the antimitotic gene nm2 $23^{29}$. Additionally, increasing evidence ascribes an independent predictive and prognostic role to alterations of the p53 tumour-suppressor gene ${ }^{30}$ and microvessel density ${ }^{31}$. These factors may be helpful in the future to identify appropriate anticancer therapy. 


\section{REFERENCES}

1. Early Breast Cancer Trialists" Collaborative Group. Systemic treatment of early breast cancer by hormonal, cytostatic or immune therapy. 133 randomized trials involving 31000 recurrences and 24000 deaths among 75000 women. The Lancet 1992; 339: 1-15.

2 Early Breast Cancer Trialists' Collaborative Group. Systemic treatment of early breast cancer by hormonal, cytostatic or immune therapy. 133 randomized trials involving 31000 recurrences and 24000 deaths among 75000 women. The Lancet 1992; 339: 71-85.

3 Fisher $B$, Bauer $M$, Wickerman DL et al. Relation of number of positive axillary nodes in the prognosis of patients with primary breast cancer. An NSABP update.

Cancer 1983; $51: 1551-1557$.

4 Neville AM, Bettelheim R, Gelber RD et al. Factors predicting treatment responsiveness and prognosis in node-negative breast cancer. J Clin Oncol 1992; 10: 696-705.

5 O'Reilly SM, Richards MA. Is DNA flow cytometry a useful inwestigation in breast cancer? Eur J Cancer 1992; 28: 504-507.

6 Gasparini $G$, Bevilacqua $\mathrm{P}$, Pozza $\mathrm{F}$ et al. Value of epidermal growth factor receptor status compared with growth fraction and other factors for prognosis in early breast cancer.

Br J Cancer 1992; 66: 970-976.

7 Gallagher CJ, Cairnduff F, Smith IE et al. High dose versus low dose medroxyprogesterone acetate: a randomised trial in advanced breast cancer.

Eur J Cancer Clin Oncol 1987; 23: 1895-1899.

8 Silva $A$, Tonato $M$, Bono $A$ at al. Medroxyprogesterone acetate versus tamoxifen in advanced breast cancer. Proc 10th ESMO Annual Meeting, Nice, 1984, abstract 233.

9 Fosser V. A multicenter randomised clinical trial with medroxyprogesterone acetate (MPA) at two different dose schedules versus tamoxifen (TMX) in advanced breast cancer. In: Robustelli đella Cuna Q, Nagel GA, Lanius P (eds). Progress in hormono-chemotherapy (Kehrer Verlag Freiburg, 1985: 79-83).

10 van Veelen $H$, Willemse $H B$, Tjabbes $T$ et al. High dose medroxyprogesterone acetate versus tamoxifen. Cancer 1986; 58: 7-13.

11 Ward RL, Morgan G, Dalley D, Kelly PJ. Tamoxifen reduces bone turn over and prevents lumbar spine and proximal femoral bone loss in early postmenopausal women.

Bone Miner 1993; $22(2): 87-94$.

12 Love RR, Wiebe DA, Feyzi JM et al. Effects of tamoxifen on cardiovascular risk factors in postmenopausal women after 5 years of treatment.

J Natl Cancer Inst 1994; 86 (20): 1534-1539.

13 van Leewwen FE, Benrastt $J$, Coebergh JW et al. Risk of endometrial cancer after tamoxiten treatment of breast cancer. Lancet 1994; 343: 448-452.

14 Schouten LJ, Volovics A, Hupperets PSGJ et al. High dose medroxyprogesterone acetate (MPA) and the risk of contralateral breast cancer. Abstract SER, June 1995, Snowbird.

Am J Epidemiology 1995; 141: abstract 262/

15 Raemaekers JMM, Beex LVAM, Koenders AJM et al. Disease-free interval and oestrogenreceptor activity in tumour tissue of patients with primary breast cancer: an analysis after long-term follow-up. Breast Cancer Res Treat 1995; 6: 345-354.

16 Sigurdsson H, Badetorp B, Borg A et al. Indicators of prognosis in node-negative breast cancer. N Engl J Med 1990; 322: 1045-1053.

17 Silvestrini $R$, Daidone $M G$, Valagussa $P$ et al. 3H-thymidine labelling index as a prognostic indicator in node-positive breast cancer. J Clin Oncol 1990; 8: 1321-1326.

18 Tubiana $\mathrm{M}$, Pejovic $\mathrm{MH}$, Chavaudra $\mathrm{N}$ et al. The long-term prognostic significance of the thymidine labelling index in breast cancer. Int J Cancer 1984; 33: 441-445. 
19 Visscher DW, Wykes $s$, Kubus $r$, Crissman JD. Comparison of PCNA/cyclin immunohistochemistry with flow cytometric $S$-phase fraction in breast cancer.

Breast Cancer Res and Treatm 1992; 22: 111-118.

20 Leers $M P$, Theunissen PHMH, Schutte B, Ramaekers FCS. Bivariate cytokeratin/DNA flow cytometric analysis of paraffin-embedded samples from colorectal carcinoma. Cytometry 1995 , in press.

21 Tubiana M, Pejovic MH, Renaud A et al. Kinetic parameters of disease in breast cancer. Cancer $1981 ; 47: 937-943$.

22 Tubiana $M$, Pejovic MH, Chavaudra $\mathrm{N}$ et al. The long-term prognostic significance of the thymidine labelling index in breast cancer. Int J Cancer 1984; 33; 441-445.

23 Silvestrini $\mathrm{R}$, Daidone $\mathrm{MG}$, Valagussa $\mathrm{P}$ et al. ${ }^{3} \mathrm{H}$-thymidine labelling index as a prognostic indicator in node-positive breast cancer. I Cllin Oncol 1990; 8: 1321-1326.

24 Slamon DJ, Clark GM, Wong SG et al. Human breast cancer: correlation of relapse and survival with amplification of the HER-2/Neu oncogene. Science $1987 ; 235: 177-182$.

25 Klijn JGM, Barns PMJJ, Foekens JA. The clinical significance of epidermal growth factor receptor (EGF-R) in human breast cancer: a review on $\$ 232$ patients.

Endocrine Rev 1992; 13: 3-18.

26 Sainsbury $J R$, Farndon $\mathrm{JR}_{\mathrm{R}}$, Needham GK et al. Epidermal growth factor receptor status as predictor for early recurrence of and death from breast cancer. Lancet 1987; 1: 1398-1402.

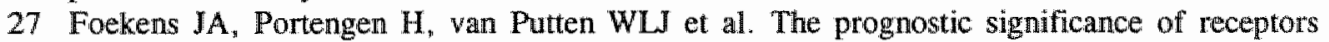
for insulin like growth factor-1, somatostatin and epidermal growth factor in human primary breast cancer. Cancer Res 1989; 49: 7002-7009.

28 Tandon AK, Clark GM, Chamness GC et al. Cathepsin D and prognosis of breast cancer. N Engl J Med 1990; 322: 297-302.

29 Colm H, Henry JA, May FEB et al. Expression of the antimetastatic gene nm23 in human breast cancer: an association with good prognosis. J Natl Cancer Inst 1991; 83: 281-285.

30 Ostrowski JL, Sawan A, Henry L et al. p53 expression in human breast cancer related to survival and prognostic factors: an immunohistochemical study. J Pathol 1991; $164: 75-81$.

31 Weidner N, Folkman J, Pozza $\mathrm{F}$ et al. Tumour angiogenesis: a new significant and independent prognostic indicator in early stage breast carcinoma.

J Natl Cancer Inst 1992; 84: 1875-11887. 
SAMENVATTING 


\section{SAMENVATTING}

Mammacarcinoom is een heterogene en complexe aandoening waarvoor in de nabije toekomst geen dramatische verbetering in de overleving te verwachten is. Het meest tot de verbeelding sprekend resultaat is bereikt door middel van adjuvant chemotherapie bij premenopausale patiënten en langdurig adjuvant tamoxifen-behandeling bij postmenopausale patiënten.

Het laatste decennium is gekenmerkt door bestudering van een groot aantal biologische factoren, die van invloed zouden kunnen zijn op de ontwikkeling van normaal tot abnormaal mamma-weefsel en op metastaseringsprocessen van tumorcellen. Hoewel op dit moment een 60-tal variabelen onderzocht zijn, wordt de keuze van behandeling bij patiënten met een mammacarcinoom vooralsnog empirisch bepaald en slechts in geringe mate beïnvloed door biologische factoren.

In dit onderzoek bij klier-negatieve en klier-positieve mammacarcinoompatiẽnten, waarbij diagnose stadiëring en locoregionale therapie uniform werden toegepast, hebben wij getracht klinische en biologische kenmerken en aspecten van behandeling te relateren aan prognose en respons op de behandeling.

In hoofdstuk II zijn de klinische resultaten beschreven van postoperatieve chemohormonale therapie vergeleken met chemotherapie alleen bij klier-positieve borstkankerpatiënten. Patiènten $\geq 60$ jaar toonden een significant betere overleving indien medroxyprogesteron acetaat (MPA) werd toegevoegd aan de chemotherapie. Dit verschil ten gunste van de gecombineerde chemo-hormonale behandeling is mogelijk te verklaren op basis van hogere oestrogeen receptorwaarden bij oudere patiënten. Bij patiënten $\leq 40$ jaar werd een nadelig effect gezien bij de combinatie van chemotherapie en medroxyprogesteron acetaat (MPA) hetgeen zeer waarschijnlijk te verklaren is op basis van het achterwege blijven van door chemotherapie geïnduceerde ovariële ablatie bij toediening van hoge dosis progestagenen.

De hoge dosis MPA had een aantal nadelige effecten, namelijk gewichtstoename en abcessen als gevolg van intramusculaire toediening van MPA. Aangezien lage dosis MPA (300 mg p.o.) hetzelfde remissiepercentage heeft in vergelijking met hoge dosis MPA (900 mg p.o.) zou in de adjuvantsetting een lage orale dosis gebruikt kunnen worden om deze bijwerkingen te voorkomen. Aangezien hoge dosis MPA even effectief 
is als tamoxifen in het gemetastaseerd mammacarcinoom verdient onderzoek met lage dosis MPA (300 mg p.o.) als adjuvant behandeling bij postmenopausale lymfklierpositieve mammacarcinoompatiënten een plaats. Men zou kunnen denken aan een klinisch vergelijkend onderzoek waarbij bovengenoemde MPA-dosering vergeleken wordt met de standaard-behandeling tamoxifen $20 \mathrm{mg}$. Tamoxifen $20 \mathrm{mg}$. toegediend gedurende een periode van 2 a 3 jaar heeft interessante neveneffecten zoals voorkoming van osteoporose en cardiovasculaire complicaties. Eveneens verminderd tamoxifen de incidentie van contralateraal mammacarcinoom, echter verhoogd mogelijk het risico op endometriumcarcinoom. Dit laatst genoemd probleem treedt niet op bij medoxyprogesteron acetaat en wat betreft het contralateraal mammacarcinoom heeft onderzoek, verricht door onze groep, aangetoond dat MPA even effectief is als tamoxifen voor wat betreft preventie van contralateraal mammacarcinoom.

Concluderend kan gesteld worden dat het momenteel nog te vroeg is om op grote schaal anti-oestrogenen te vervangen door progestagenen bij de adjuvant behandeling vam klierpositieve postmenopausale mammacarcinoom patiënten. Onderzoeken waarbij langdurig tamoxifen gebruik vergeleken wordt met kortdurend en langdurend oraal progestageengebruik zijn noodzakelijk om effectiviteit en bijwerkingen van deze middelen te vergelijken.

In hoofdstuk III worden steroïdreceptoren als prognostische factoren bij het mammacarcinoom bestudeerd. In de literatuur wordt als afkappunt voor de steroildreceptoren meestal $10 \mathrm{fmol} / \mathrm{mg}$ eiwit gehanteerd. In hoofdstuk III is de oestrogeen en de progesteronreceptor als een continue variabele bestudeerd en is voor elke waarde het relatieve risico bepaald.

Klier-negatieve mammacarcinoompatiënten met oestrogeenreceptorwaarden tussen de 100 en $400 \mathrm{fmol} / \mathrm{mg}$ eiwit hebben een significant lager risico in vergelijking met patiënten met oestrogeenreceptorwaarden $<100$ of $>400$. Patiënte met zeer hoge ER-waarden ( $>400 \mathrm{fmol} / \mathrm{mg}$ ) hadden een duidelijk slechtere prognose, echter dit fenomeen zou beînvloed kunnen zijn door het lage aantal patiënten in deze groep.

In de klier-positieve patiènten is een afkapwaarde van $10 \mathrm{fmol} / \mathrm{mg}$ eiwit een tijdsafhankelijke prognostische factor, dat wil zeggen dat een oestrogeenreceptorwaarde van $\leq 10 \mathrm{fmol} / \mathrm{mg}$ gedurende de eerste 5 jaren na de diagnose een prognostisch ongunstige betekenis heeft.

De progesteronreceptor is een tijdsafhankelijke prognostische factor bij klier-negatieve patiënten. Patiënten met een progesteronwaarde $\leq 80 \mathrm{fmol} / \mathrm{mg}$ eiwit hebben de eerste 5 jaren na de diagnose een significant hoger risico op metastasen op afstand en een hoger risico om te overlijden als gevolg van het mammacarcinoom in vergelijking met patiënten die een progesteronreceptorwaarde hebben die $>80 \mathrm{fmol} / \mathrm{mg}$ eiwit bedraagt. In de klierpositieve patiënten wordt een afkappunt voor de progesteronreceptorwaarde gezien die licht verschilt ten opzichte van de klier-negatieve patiënten (60 fmol/mg) en wordt bij een waarde van $\leq 60$ een significant hoger risico waargenomen. Dit effect is onafhankelijk van de follow-up duur.

Deze gegevens en de literatuurgegevens laten geen gefundeerde conclusies toe omtrent het gebruik van de steroïdreceptor als prognostische factor voor patiënten met een 
resectabel mammacarcinoom. Twee facetten in onze studie zijn opvallend. Op de eerste plaats de tijdsafhankelijkheid van de prognostische factor. In onze studie is een lage oestrogeenreceptor waarde bij klier-positieve patiênten en een lage progesteronreceptor waarde bij klier-negatieve patiënten een prognostisch ongunstige factor gedurende de eerste 5 jaren na de diagnose. Dit effect verdwijnt na een follow-up periode van 5 jaar. Het is niet geheel duidelijk wat de oorzaak is van dit fenomeen; mogelijk moeten we de oorzaak zoeken in een langere overleving vanaf het moment van recidief bij patiènten met een steroïdreceptor positieve tumor, mogelijk dat het verschil veroorzaakt wordt door een voorbijgaand effect van de adjuvante therapie. Het tweede aspect dat in onze studie naar voren toe komt is de bepaling van de afkappunten van de steroïdreceptorwaarden. Onze resultaten laten zien dat de prognostische betekenis van de steroidreceptor verdwijnt indien traditionele afkappunten worden gehanteerd. Beschouwen we de oestrogeenreceptor als een continue variabele dan bleek in ons onderzoek dat patiënten met een zeer hoge waarde een ongunstige prognose hadden. Gezien het lage aantal patiënten in deze groep was het niet mogelijk om een relatie te leggen met bijvoorbeeld de leeftijd en het MPA-effect in deze prognostisch ongunstige groep.

Concluderend kan gesteld worden dat de steroidreceptorstatus aen moeilijk te beoordelen een niet al te betrouwbare prognostische factor is. Zeer waarschijnlijk ligt de waarde meer in de predictieve kracht om een positief behandelingsresultaat te voorspellen bij adjuvante endocriene therapie.

In hoofdstuk IV worden de resultaten beschreven van DNA-flow cytometrie (FCM) bij klier-negatieve mammacarcinoom patiënten. Aneuploidie, echter niet SPF, is een onafhankelijke prognostische factor in de multivariate analyse. Echter de prognostische waarde van aneuploidie is niet hoog genoeg om routine-matig toe te passen bij patiënten met een mammacarcinoom.

In tegenstelling tot een aantal publikaties bleek in ons onderzoek dat SPF geen onathankelijke prognostische factor was. Dit wordt gedeeltelijk veroorzaakt doordat in een hoog percentage van de DNA-histrogrammen de SPF-bepaling niet mogelijk was. Deze groep heeft in ons onderzoek een gunstige prognose en dienen hoogst waarschijnlijk in de lage SPF-groep te worden geclassificeerd indien gebruik gemakt zou zijn van een computermodel om alsnog SPF te bepalen.

$\mathrm{Na}$ onze mening dient de conclusie van dit hoofdstuk te zijn dat de correlatie tussen SPF en prognose afhankelijk is van de procedure die gevolgd is om DNA-histrogrammen met overlappende aneuploïde populaties of relatief kleine aneuploïde populaties te beoordelen. In onze ogen is de cetrouwbaarheid van de SPF-bepaling door middel van computermodellen voor het mammacarcinoom discutabel.

Dit wil niet zeggen dat bepaling van het percentage prolifererende cellen niet van belang zou zijn bij de prognose bij het mammacarcinoom. Onderzoeken met thymidineincorporatie hebben aangetoond dat dit zeker het geval is, echter deze methode is zeer bewerkelijk en tijdrowend. Nieuwe technieken om het aantal prolifererende cellen te bepalen zoals de PCNA-techniek en het bepalen van SPF op alleen do tumorcelpopulaties, gebruik makend van proliferatie en cellulaire makers kunnen meer inzicht geven in de relatie tussen proliferatie-prognose. 
In hoofdstuk $\mathrm{V}$ worden de resultaten van flow cytometrie in klier-positieve patiënten beschreven. Uit ons onderzoek blijkt dat ploiddy noch SPF bijdragen aan het bepalen van de prognostische betekenis bij klier-positieve patiënten. In een meer gedetailleerde analyse bleek dat diploide patiënten een gunstiger prognose hadden ten opzichte van aneuploïde patiërnten indien in de adjuvante behandeling progestagenen aan de chemotherapie werden toegevoegd. Eveneens was opvallend dat bij de patiëntengroep met een lage SPF-waarde $(<8 \%)$ toevoeging van MPA een negatieve invloed had op de prognose.

Hoewel deze resultaten interessant zijn dienen we bij de interpretatie hiervan voorzichtigheid te betrachten. Het betreft hier een sub-groepanalyse en de resultaten zijn retrospectief onderzocht. De resultaten onderstrepen wel dat we rekening dienen te houden met factoren die behandelings afhankelijk (predictieve factoren) en behandelings onafhankelijk zijn.

Gezien het vastgestelde resultaat zou het interessant zijn andere studies met eenzelfde randomisatie retrospectief te analyseren voor wat betreft de predictieve effecten van ploidy en proliferatie. Vooral de onderzoeken waarbij al of niet tamoxifen werd toegevoegd aan chemotherapie in de adjuvant-setting zijn interessant wat betreft dit aspect. Indien onze bevindingen worden bevestigd zou dit een prospectief onderzoek rechtvaardigen wat bij ploïdy en SPF als stratificatie-factoren zullen worden onderzocht.

Hoofdstuk VI vergelijkt ploïdy en SPF in primaire mammacarcinomen en nodale metastasen. Dit onderzoek laat zien dat verschillen in DNA-plö̈dy tussen de primaire tumor en de nodale metastase veroorzaakt worden door intratumorale heterogeniteit. Het percentage S-fase cellen was in tumorcellen gemetastaseerd naar axillaire klieren significant lager dan de corresponderende primaire tumor. Ons inziens kan dit niet worden verklaard op grond van een daling van de SPF als gevolg van vermenging met lymfoïde cellen met een lage proliferatiefractie. Mogelijk dat er een proliferatieremmende factor uitgaat van de lymfatische cellen; mogelijk dat de afwezigheid van stroma-afhankelijke stimulatoren voor proliferatie een verklaring zijn voor dit fenomeen.

In hoofdstuk IV en V, maar ook in hoofdstuk VI werden SPF-berekeningen niet verricht met behulp van computermodellen. Uit onze data en ook uit de data van de literatuur is bekend dat variaties als gevolg van de plaats waar het biopt genomen is (samplingvariaties) veel belangrijker zijn dan de variaties veroorzaakt door de verschillende methoden om SPF-waarden te berekenen. Naar onze mening is het met behulp van computermodellen mogelijk om een hoger percentage SPF-waarde te bepalen, echter betekent dit niet dat hiermee ook de nauwkeurigheid wordt verhoogd.

Uit dit hoofdstuk kan geconcludeerd worden dat er geen noodzaak bestaat om DNA-flow cytometrie te verrichten van axillaire lymfeklieren bij patiënten met een klier-positief mammacarcinoom.

Eindconclusie.

Indien we alle onderzochte variabelen bij klier-positieve mammacarcinoom patiënten kritisch beschouwen blijkt dat het aantal tumor bevattende axillaire lymfeklieren de meest belangrijke prognostische factor blijft. ER is een tijdsafhankelijke predictor voor DMFS 
en OS en de PgR heeft een predictieve warde voor wat betreft de DMFS en OS. Echter met de prognostische factoren die we hebben bestudeerd is het vooralsnog niet mogelijk om klier-positieve patiënten met een gunstige prognose voor wie adjuvant chemotherapie niet is geindiceerd of anderzijds de groep van klier-positieve patiënten die geen gunstig effect hebben van de adjuvant therapie te identificeren. We hebben behoefte aan een aantal betrouwbare prognostische factoren om de groep van $30 \%$ van de klier-positieve mammacarcinomen die ziektevrij blijven en de groep van $30 \%$ van de klier-negatieve patiënten die zullen recidiveren te identificeren.

Een groot aantal nieuwe variabelen zijn de laatste jaren onderzocht en worden momenteel onderzocht naar de prognostische betekenis. Naast proliferatiefactoren wordt momenteel onderzoek verricht naar factoren die van belang zijn bij geprogrammeerde celdood (apoptosis) en worden de verschillende factoren die van belang zijn bij het proces van metastasering onderzocht. Deze factoren kunnen van belang zijn om in de toekomst de behandeling bij het mammacarcinoom beter af te stemmen. 


\section{PUBLICATIONS}




\section{PUBLICATIONS}

Blijham GH, Wils J, Schouten L, Hupperets P, Jager J, de Jong J, von Meijenfeldt M, Fickers $M$, Bron $H$. Adjuvant therapy with high dose medroxyprogesterone acetate (MPA) if added to chemotherapy in patients with node-positive operable breast cancer. Annals of Oncology 1: 19, 1990.

Hupperets PSGJ, Blijham GH, Wils J, Schouten L, Jager J, von Meijenfeldt M, Fickers $\mathrm{M}$, Bron $\mathrm{H}$, Volovics $\mathrm{L}$. Adjuvant therapy with high dose medroxyprogesterone acetate (MPA) if added to chemotherapy (FAC) in patients with node-positive operable breast cancer. Annals of Oncology 4, nr.4: 295-301, 1993.

Hupperets P, Schutte B, van Assche C, Schouten LJ, Jager J, de Jong J and Blijham GH. Ploidy and S-phase fractions (SPF) of primary breast cancers and their nodal metastases. Breast Cancer Research and Treatment 32: 197-202, 1994.

Hupperets P, Wils J, Volovics L, Schouten L, Fickers M, Bron H, Schouten H, Jager J, Smeets J, de Jong J, Blijham G. Adjuvant chemo-hormonal therapy with cyclophosphamide, doxorubicin and 5-fluorouracil (CAF) with or without medroxyprogesterone acetate (MPA) in node-positive breast cancer patients. In: Cancer Treatment An Update. Banzet P, Holland JF, Khayat D, Weil M (eds). Springer Verlag, p. 155-159, 1994.

Hupperets P, Wils J, Volovics L, Schouten L, Fickers M, Bron H, Schouten H, Jager J, de Jong J, Beex L, Hillen H, Blijham G. Adjuvant chemo-hormonal therapy with cyclophosphamide, doxorubicin and 5-fluorouracil (CAF) with or without medroxyprogesterone acetate for node-positive cancer patients. Update at 7-year follow-up. Annals of Oncology 6: 90-91, 1995.

Jager JJ, Langendijk JA, Dohmen JP, Schreutelkamp L, Volovics L, van Engelshoven M, de Jong JM, Schouten LJ, Hupperets PS and Blijham GH. Mammography in the follow-up after breast-conserving treatment in cancer of the breast: suitability for mammographic interpretation, validity and interobserver variation. The British Journal of Radiology 68: 754-760, 1995. 


\section{ABSTRACTS}

Thunissen FBJM, de Goej AFPM, Hupperets P, Schouten LJ, Kuijpers-Engelen B, Pijls M, Knops C, Peterse JL, Blijham GH, Bosman FT. DNA and receptor quantitation. Proceedings of the Becton and Dickinson Cytometry Users Group Meeting, Rolduc, 6-7 juni 1990.

Blijham GH, Wils J, Schouten L, Hupperets P, Jager I, de Jong J, von Meijenfeldt $M$, Fickers M, Bron H. Adjuvant therapy with high-dose medroxyprogesterone acetate (MPA) if added to chemotherapy in patients with node-positive operable breast cancer. XV Congress of the European Society for Medical Oncology, Copenhagen, 2-5 december 1990 .

Hupperets PSGJ, Blijham GH, Schouten L, Jager J, Schutte B, de Jong J. Ploidy and S-phase fractions (SPF) of primary breast cancers and their nodal metastases. Nederlandse Internistendagen, Veldhoven, 18-19 april 1991.

Hupperets PSGJ, Blijham GH, Schouten L, Jager J, Schutte B, de Jong J. Ploidy and S-phase fractions (SPF) of primary breast cancers and their nodal metastases. Proceedings 5th Breast Cancer Working Conference, Leuven, 3-6 september 1991.

Hupperets PSGJ, Blijham GH, Schouten L, Jager J, Schutte B, de Jong J. Ploidy and S-phase fractions (SPF) of primary breast cancers and their nodal metastases. ECCO 6 , Firenze, 27-31 oktober 1991.

Hupperets P, Blijham G, Wils $J$, Schouten L, Jager J, von Meijenfeldt M, Fickers M, Bron $\mathrm{H}$, Volovics L. Adjuvant therapy with high-dose medroxyprogesterone acetate (MPA) if added to chemotherapy (FAC) in patients with node-positive operable breasit cancer. Breast Cancer Research and Treatment, abstract 110b, 1992.

Hupperets P, Blijham G, Wils J, Schouten L, Jager J, Fickers M, Bron H, Volovics L. Adjuvant therapy with high-dose medroxyprogesterone acetate (MPA) if added to chemotherapy (FAC) in patients with node-positive operable breast cancer. 15 th Annual San Antonio Breast Cancer Symposium, San Antonio, 9-10 december 1992.

Hupperets P, Blijham G, Wils J, Schouten L, Jager J, Fickers M, Bron H, Volovics L. Adjuvant therapy with high-dose medroxyprogesterone acetate (MPA) if added to chemotherapy (FAC) in patients with node-positive operable breast cancer. Fourth International Congress on Anti-Cancer Chemotherapy. Parijs, 2-5 februari 1993, abstract 5, p. 59 .

Hupperets P, Volovics L. Schutte B, Schouten L, Jager J, Schouten H, Blijham G. The prognostic value of flow cytometry (FCM) in stage I and II breast cancer patients. Proceedings American Society of Clinical Oncology 12: 78, 1993. 
Hupperets P, Blijham G, Volovics L, Schutte B, Schouten L, Jager J, de Jong J, Schouten $\mathrm{H}$, Hillen $\mathrm{H}$. The prognostic value of flow cytometry (FCM) in node-positive breast cancer patients. Proceedings of the American Society of Clinical Oncology 13: abstract 147, 1994.

Hupperets P, Blijham G, Volovics L, Schutte B, Schouten L, Jager I. de Jong I, Schouten H, Hillen $\mathrm{H}$. The prognostic value of flow cytometry (FCM) in node-positive breast cancer patients. European Journal of Cancer 30A; suppl.2: S48, 1994.

Hupperets P, Blijham G, Wils J, Schouten L, Jager J, Fickers M, Bron H, Volovics L and Hillen $H$. Adjuvant therapy with high-dose medroxyprogesterone acetate (MPA) if added to chemotherapy (FAC) in patients with node-positive operable breast cancer. Anti Cancer Drugs 6; suppl 2: 82, 1995.

Schouten LJ, Volovics A, Hupperets PSGJ, Jager JJ, Thunnissen FBJM, Verbeek ALM, Blijham GH. High-dose medroxy progesterone acetate (MPA) and the risk of contralateral breast cancer (CLBC). American Journal of Epidemiology 1995; 141: abstract 262 . 


\section{DANKWOORD}




\section{DANKWOORD}

$\mathrm{Bij} \mathrm{het} \mathrm{afronden} \mathrm{van} \mathrm{dit} \mathrm{proefschrift} \mathrm{gaat} \mathrm{mijn} \mathrm{woord} \mathrm{van} \mathrm{dank} \mathrm{uit} \mathrm{naar} \mathrm{de} \mathrm{Faculteit} \mathrm{der}$ Geneeskunde van de Rijksuniversiteit Limburg, van waaruit dit onderzoek werd gesteund. Tevens gaat mijn dank uit naar het Directoraat en de Registratie Afdeling van het Integraal Kankercentrum Limburg (IKL), waar alle klinische gegevens van de in dit proefschrift beschreven patiënten zijn geregistreerd en bewerkt.

De medewerkers van de afdelingen Pathologie, van de poliklinieken Chirurgie en Interne Geneeskunde van alle ziekenhuizen uit de IKL-regio hebben met veel toewijding PAmateriaal en statussen van patiënten opgezocht.

Chris van Assche en Michèle Reijnders hebben talloze kernsuspensies gemaakt en met een engelengeduld DNA-histogrammen bestudeerd, onder de bezielende leiding van Dr. Bert Schutte.

Lex Volovics van de Afdeling Medische Statistiek heeft met veel kundigheid deze brij van gegevens omgevormd tot inzichtelijke en waardevolle gegevens.

Grote dank ben ik verschuldigd aan Mieke Haemers, die met veel inzet en toewijding mijn gedachtespinsels op papier heeft gezet en herhaaldelijk heeft gecorrigeerd.

Bijzonder erkentelijk ben ik Tiny Wouters-Lenssen en de AV-Dienst van het Academisch Ziekenhuis Maastricht voor het uitprinten van het manuscript en de grafieken, zodat deze op tijd bij de drukker afgeleverd konden worden.

Niet in het minst vermeld ik de promotores Prof.Dr. Geert Blijham, Prof.Dr. Harry Hillen en Dr. Harry Schouten, onder wiens kritische begeleiding dit werk is tot stand gekomen. Eveneens wil ik wijlen Prof.Dr. Guus Flendrig als stimulator achter de schermen niet onvermeld laten.

Tenslotte gaat mijn dank uit naar Els, Erik, Joris en Maarten, voor het feit dat zij zonder al te veel morren mijn werkzaamheden tijdens weekends en vrije dagen hebben geaccepteerd. 


\section{CURRICULUM VITAE}




\section{CURRICULUM VITAE}

De auteur van dit proefschrift is in de periode 1972-1975 praktiserend huisarts geweest te Geleen, in samenwerking met Drs P Mekel. Na een periode werkzaam te zijn geweest in het Dr A Mathijssen Ziekenhuis te Utrecht (Dr M van Zoeren, Dr A van Belle) en in het St.Joseph Ziekenhuis te Kerkrade (Drs J Scherpbier), begon hij de opleiding interne geneeskunde in het Annadal Ziekenhuis te Maastricht (1976-1978 opleider Drs I Coenegracht). Deze opleiding werd voltooid bij Prof Dr C Majoor, hoofd en opleider van de Afdeling Interne Geneeskunde aan de Katholieke Universiteit te Nijmegen.

Verdere bekwaming in de Haematologie (Prof Dr C Haanen) en de oncologie (Prof Dr DJTh Wagener) vond plaats aan voornoemde universiteit.

Sedert mei 1983 is hij verbonden aan de Afdeling Interne Geneeskunde van het Academisch Ziekenhuis te Maastricht (hoofd: Prof Dr JA Flendrig). 